The Relevance of Japanese Finance and its Main Bank System

\author{
Hugh T. Patrick
}

Working Paper No. 75

Working Paper Series

Center on Japanese Economy and Business Graduate School of Business

Columbia University

September 1993 
Final Revision

Sept. 1993

\title{
The Relevance of
}

\section{Japanese Finance and its Main Bank System}

\author{
Hugh T. Patrick \\ Center on Japanese Economy and Business \\ Columbia University
}

This paper is the final draft for the joint research project on the Japanese Main Bank System and its Relevance for Developing Market and Transforming Socialist Economies, undertaken under the auspices of the World Bank EDI Program for the Study of Japan's Development Management Experience, the Center on Japanese Economy and Business at Columbia University, and the Economy of Japan Program at Center for Economic Policy Research of Stanford University. This paper represents the views of the author and not those of the sponsoring institutions.

Project Manager

Hyung-Ki Kim
Project Coordinators

Masahiko Aoki

Hugh T. Patrick 
Contents

1 Analytical Issues
1.1 What Periods of Japanese Financial Development are Relevant and for Whom?
1.2 Fundamental Characteristics of the Japanese Main Bank System

2 Systemic Issues and Macroeconomic Performance

2.1 Japan's Economy and Finance in the High Growth Era

2.2 Some Important Institutional Features

3 Financial System Architecture and the Japanese Experience
3.1 Banking and Securities Markets
3.2 Banking System Structure
3.3 Banking System Safety and Stability
3.4 Low Interest Rates and Financial Repression
3.5 Directed Credit and Long-term Financing of Business Investment

$4 \quad$ Banking System Issues
4.1 The Governance of Banks
4.2 . Credit Analysis and Human Resource Requirements
4.3 The Financing of Small Business Relative to Large

5 Lessons From Japan's Financial Development
$5.1 \quad$ General Lessons
5.1.1 Macroeconomic Stability
5.1.2 The Structure of the Financial System
5.2 Financial Public Policy Issues
5.2.1 Deposit Safety, Bank Safety, and Prudential Regulation
5.2.2 Low Interest Rate Policies and Financial Repression
5.2.3 Directed Credit
5.2.4 Avoidance of Rent-Seeking and Corruption
5.3 The Main Bank System as a Model
$\begin{array}{ll} & \text { for Financing Large Industrial Enterprises } \\ \text { 5.3.1 Issues in Transferring the Main Bank System }\end{array}$
5.3.2 Special Problems of the Transforming Socialist Economies 
The Relevance of dapancese I inances and ils Main Rank Sysitem

llugh 1. Patrick

What Iessons can be Icarned from the Japanese expererence with its main bank systerm

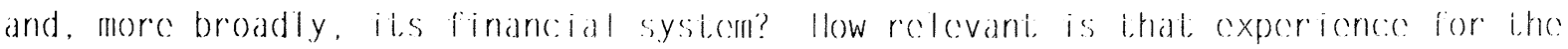

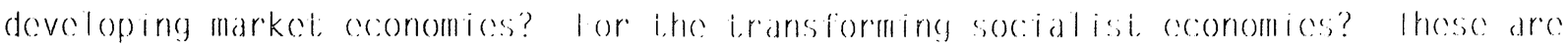
the contral themes of this chapter, which cexplores a range of key egenerie issucs in the design of good financial sysicems for developing market, and i,ransforming socialist coonomics in light of dapancese experience consonani, with ihe objectives of this book, a major focus is on the main bank systern in ils heyday, namely the rapid growth era from the carly 19t0)s to the carly $19 / 0$ s; and on placing the ma in bank system within the overall architecture of the Japancese financial system. ils structure and the gevernment's financial policies. $\backslash 1$

$\wedge$ comparalive analysis from the perspective of the banking systems of other countiries is provided by this part of the book. The next, chapter, in providing an analysis of the relationships among large cicrman banks and large industrial corporations, makes cilcar that while dapancese and cerman banking are broddly

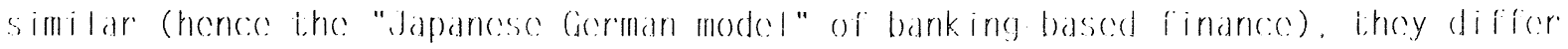
significantly in cortain detiails, cespecially in regards to corporate governance. the remaining five chapters illuminate the issues of finance and banking from the perspectives and in light of the experiences of three major developing market. conomics Korca, India, and Mexico and two transforming socialist coconomices

1. Ihis essay is based upon the chapters in this book and upon a wider body of rescarch on the Japanese financial system. I am especcially indebticd to the other authors and participants in the projoct workshops for their substantive comments. I particularly acknowledge the writinges over the years of Jure leranishi; the recentily completed prejecei on the financial development of Japan, Korea, and laiwan (Patrick and Park, 1994); and the World Bank World I)evelonment. Reporti (19839) and itis various more recent, Work ing Papers. Nonctheless, this essay is my assessment; and cevaluation, and no others are responsitzle for the judgmentis prescentied hore. 
Chind and loland. Ihose countiry studies uitile and build upon i.he thorough, detailed studies of the dapanceso ma in bank system in l'ari. I.

the nexi, secition of this chapher addreseses general andytice concerns. Ihe:

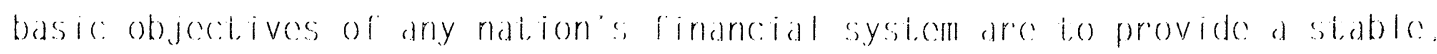
roliable, safe means of payment: to cencourage and facilitate real savine; to mobiliece those savings in financial form: and lo allocade them cefficientily and offectively to finance the most producitive invesitment projectis. A hicrarechy of issues must be considered in the cercation of a good financial systern. Ihey can be classified at lhere levels of andysis, while recognizing that interactions among issues are pervasive and importiant. Ni, the mosi, fundamental, systemice level are issues about the basic nature of the ceonomy and of macrocconomic policy. At an intermediate level are issues concerning the archilectiure of the financial systern and financial policics. $\mathrm{A}$, the micro level are issuces concerning the natures of the banking system and the cffective operation of banks. How dapan has deali. with these, and in particular how the: main bank systecm fii, ii, accordingly are discussed in the following threce scetions. Ihe relevance, lessons, and transferability of the Japanese financial systern, in particular the main bank system, lo developing market, and transforming socialist coonomies are addrecsed in the final sections of the chapter.

the approach in this chapler is lo consider key gencric colcments in the creation of a good financial systern and how dapancese policymakers, financicers, and markets have deall, with then, rather than arguing that the Japancese financial system, cespecially its main bank system, should (much loss could) simply be: replicated in other countirices. lach developing market coconomy or transforming socialist conomy (1st) has its own specific circumstances, experiences. institutions and history. Given national differences, there is no single opt, imal financial system model for all countries at all levels of development.

Unlike Part, 1, where most of he discussion focuses on the dapanese main bank system in the context of the Japancese financial systern and it.s cevolution, the approach here is to appraise the Japancse cxpericnce in light of the basic structural, institutional, and policy problems of finance that most developing 


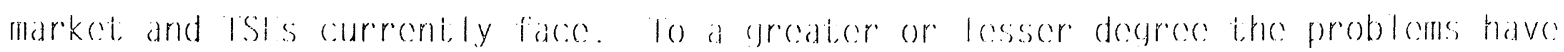
becn inflation and macrocconomic: instabiliby; weak legal, coconomis: and financial infrastructure; inadequate conomis and findancial information and ibs asymmetre distribution among conomic actors; weak banking systicms and captial markeis,

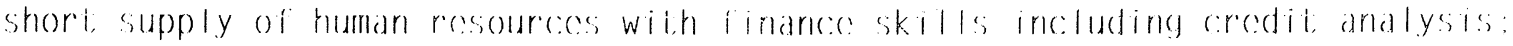
financial repressison; sofit, budegetines: and corruption

linancial systems, like ceonomices, evolve over i.jme in response lo changing conomic corcumstances and opportunities as woll as socio political conditions and obsectives. Ihe broad contours of the long run histioricial padiern of financial

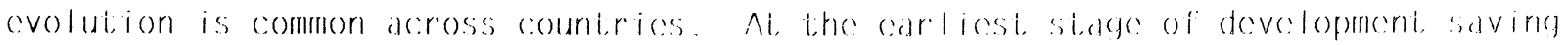
is done by investors; finances is intecrnal. Indeced inicernal finance continues i,o be the dominant source of industrial finanese ceven in the most advanced comomoces.

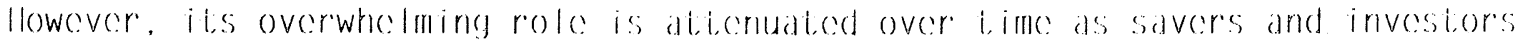
increasingly become different, cntibies and as contreprencurs and firmes develop new profitable invesiment projecets larger than can be financed internally.

In all conomies banks have becn and continue to be the dominant cexternal source of business finance, cortainly for the contire sector of smaller conterprisces and ceven for many large companies. Ni, some point and itiming differes significantly among countiries and financial instrumenis large companios obtain financing through the issuance of equity, bonds, and commerecial paper in capital markcis. Whother first to create instibutions and pursue policices favoring bank

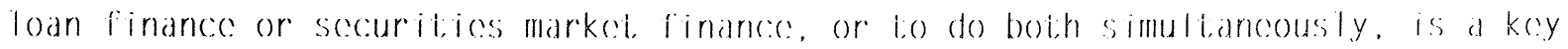
issue in designing financial systems. If priority is given to banking, as has becn the historical expericnece of financial development for many counteries, when and how is such preferential treatimeni broughti to an cond? We have lwo historical models. In the Anglo American expericence, sccuritices marketis developed carly. postwar Japan and cicrmany are major cxamples of the banking based model: sccuritices markeis have developed only reconily.

wise policymakers consider a range of allernative systems and instibititional arrangements, and learn from the successes and failures in the actual cxpericneces of other countries as well as from theory. Io narrow one's scope and perspecitive can lead to making wrong policy choices. Thus. there is always the danger of giving excessive weight to the comparative cexpericnece one knows best. lo what

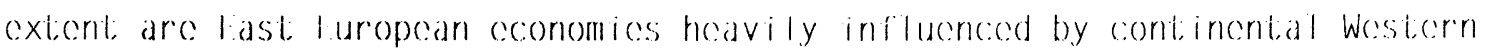
luropean models, or by adviscers intellectually grounded in the Anglo American 


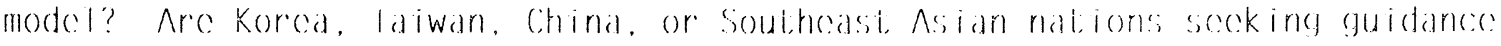

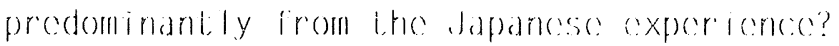

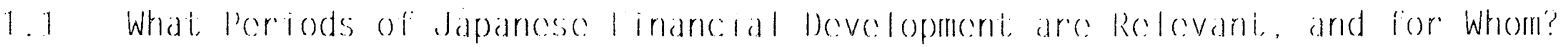

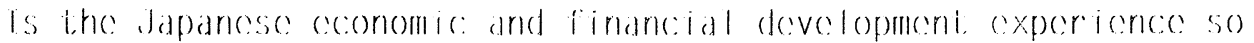
distincitive as to be considered unique? Iho answer is cortadinly no. Ihe:

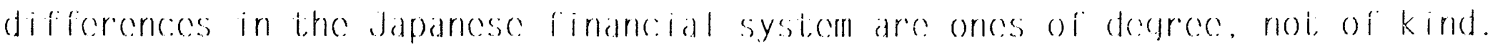
Japancse policymakers have had to deal with the same major issues in developing the architeciture and operations of il.s findancial system as have policymakers in all markel comomios.

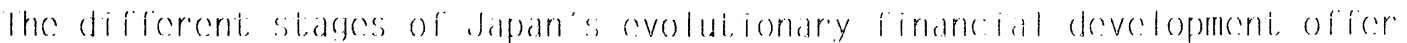
different insights lessons and hence are differentially rolovanti for

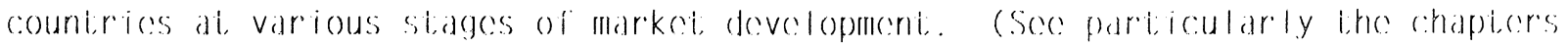

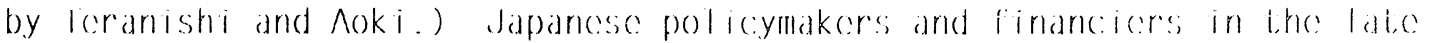
nincteconth contury cestablished a modern financial system by adopting and adapt,ing Wostern models and insibitulions. Initially contry was vary casy, with low minimum capilal requircments and virtually no prudenitial regulation or proticcition of deposits; by the first decade of the lwonticeth century some 7300 banks wore in operation, mostly small, local, unit banks costablished by industrialists secking to finance their conterprisos. The sucocsshul growth of the banking systern was

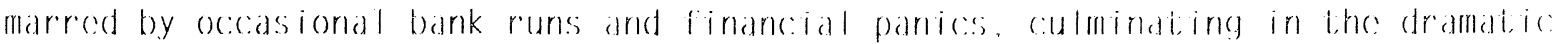
banking crists of 19\%/. Groater governmeni, recgulation. highor minimum captial requircments, consolidation, and the increasing sios and market, share of a fow large barks rosulted.

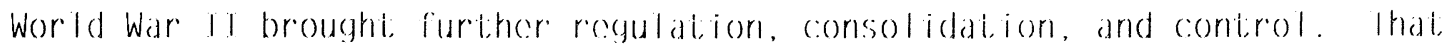
experience, ospecially coupled with the immediale posiwar expericonce of dislocation, high inflation, convorsion from munitions io civilian goods production, huge overhang of bad debis for both companices and banks, and ciforis

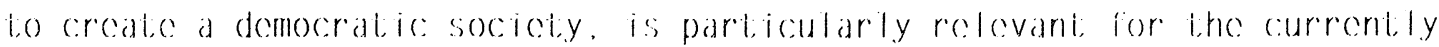
transforming luropoan socialist, coonomies. Insighis, oven lossons, can bo dorived from how dapancse policymakers dealt, with the same sorts of problems as those currontily facing lihe ISts. (Sece the chapter on Poland by lloshi cit al.) Nonciheless there are importiant differences as woll. P'orhaps most, importianti is that postwar dapan had several gencrations of prowar experience in a frece market. 
930903

III) Relevances b

private conterperise systerm in which financial instituitons becane well developed

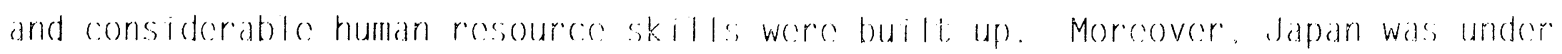

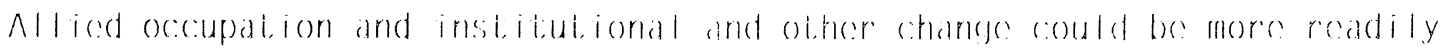

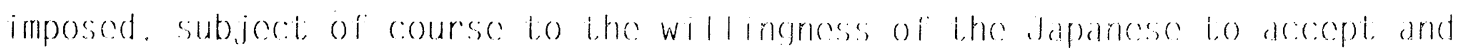
maintain ihose changes, cespecially onces independences was ressioured in 19ts?.

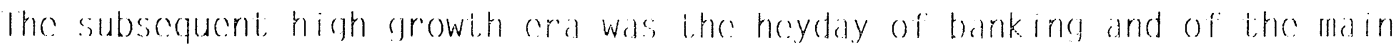

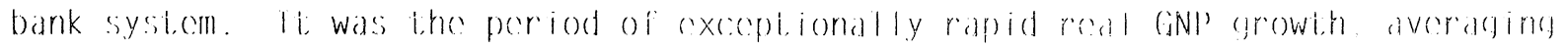

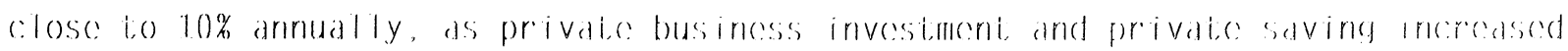
dramatically absolutely and as a share of cinte corporations necoded cever increas ing amounis and proportions of external finance, and tanks provided the grodi bulk of it. li, was an cra of modecst financial reprecession in which real

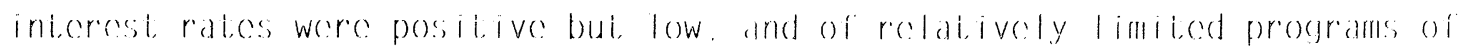

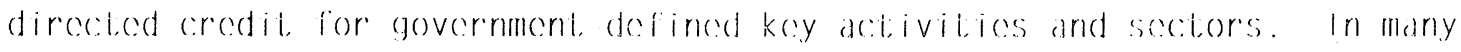

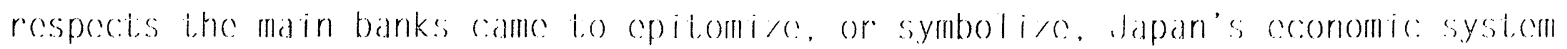
in the high growith cral And it is this cra that probably is mosi immedidicaly

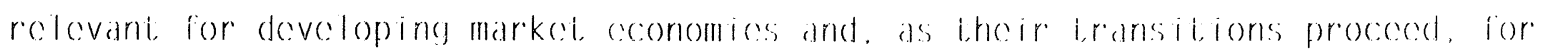
ISIS as well.

By the late stages of the high growth era the carly 19/0s both the real ceonomy and the financial systern had grown, evolved, decpened in si,ruciture. and became institutionally stronger. Ihe balance of payments constiraint on growith had becen lifted. Inflationary pressures had becen succossfully contained for more than iwo decades dapan's expori, capadeity had increased rapidly and the yen. initially overvalued. had become: undervalued. Ioan interest rates had becen positive throughout, financial markets had come: to work increasingly we:ll, and the proportion of direciced credit, for developmential purposes, never high in aggregate. had decolined substiantially. I inancial institudions and their management. capatolitios and the associated accounting, duditing, and reporiting infrastiruciture had become quite well developed. Ihe sysitern was more than ready for further financial reform: deregulation, liberalisation, a widening range of

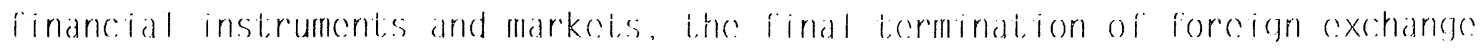
controls over capitial outhlows and inflows in other words. the transition (some would say overduc) lo a compeditive financial system (World Bank, 1989, p. 1\%/). this took place gradually and piecomeal from the mid 19/0s, and in some respectis is yci, io be compleiced. 


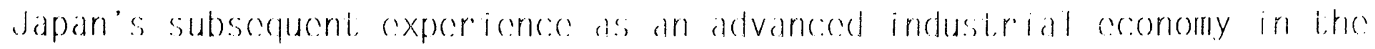

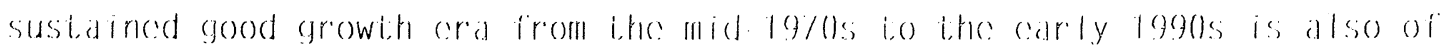

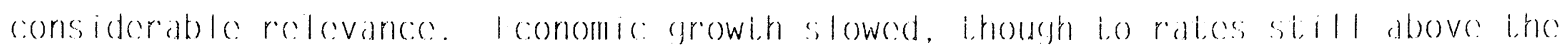

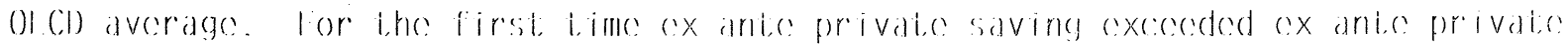
investement, and the financial systern was flush with funds. In the scecond half of

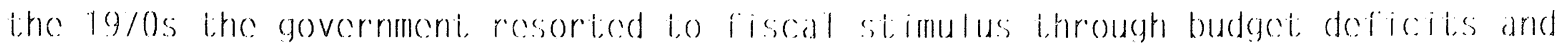

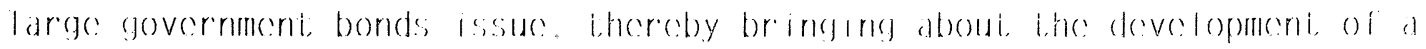

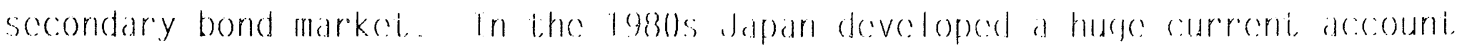
surplus. thanks in parte to the overvalued dollar. Ithe governoment dureine this

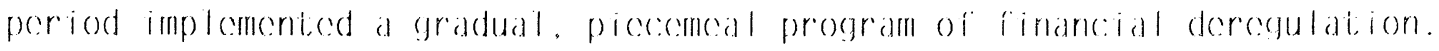
linancial repression conded and greadere compei,ition consued in mosi. financial

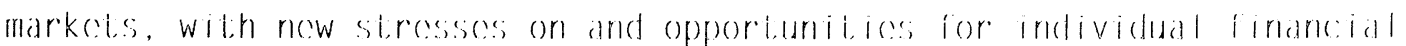
instibutions. Sccuritios markets burgeoned as many large listed firms found bond and equily issue a less expensive source of exiecrnal funds than bank loans. While the domestic corporate bond issue market remained relatively underedeveloped and restricted, luro market bond issues thrived. Inuring this period the main bank system cevolved and became combedded in market based finance.

Ihese trends were seriously exaccrbated by the asset bubthle whe great boom in the stock and land markel prices between 1985 and 1990. In retrospect this was a period of system wide fallure. Ihe speculditive manid was fed by the mistaken but widespread belicef shared coven by conservative banks and government.

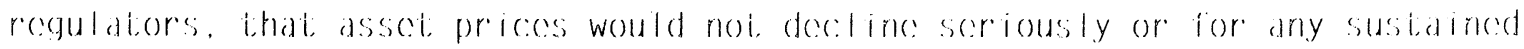
period of time. During 1983, go banks and other financial institiditons loni, on cver casicer tecrms for purchase of cever higher presced land and for real costatie development projects. The bursting of the bubthe from 1990 has left in its wake ihe difficult problems of a scrious bad debte overhang for the cntire banking systerm, the first since the late 1910s.

Japan's long historical experience as a succossful devoloping market coconomy clearly is directily relevant for other developing market coonomices which. after all, have gone through their own banking and financial market development. the isls however. have to create the fall panoply of privale ownership, capitalist. market institutions, incentives, and bechavior virtually from the ground up. Whilo: they face tremendous difficulites and obstacles in virtually croating a new financial system rather than modifying an existing one, the ISts can learn much from the Japancese model and experiones both in determining their basse financial 


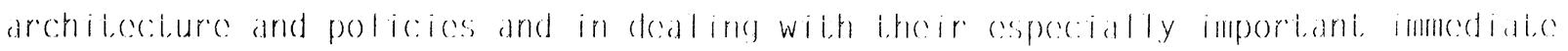

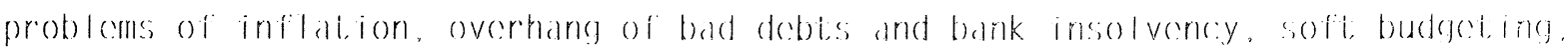
and lack of humban recesourceses.

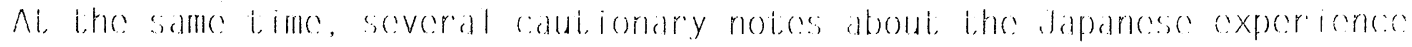

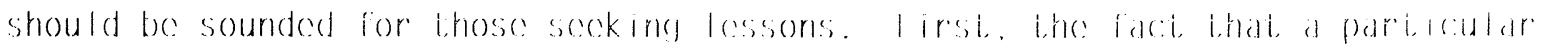
sot of policeices and insititutional arrangernent.s worked well in dapan does not, mean

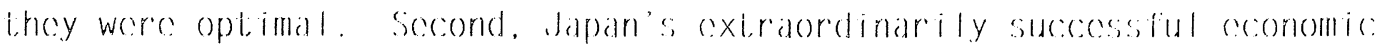
performance does not mean that, ceveryithing was done right. Ihird, the dapancese? model cannot simply be applied direcily or simply: it musi be adapted io casch country's own recquirementis. Iourth, what counts is subsiance, not form; meres adoption of institiutions or policics without appropriate incentives and reculatiory arrangementis will not, suscesed.

1.7 I undamenital Charactereristics of the Japancese Main liank Systeren

Ihe nature, operations, cefocotiveness, and cevolution of the Japancese mat in bank systern are described and analyecd in rich, nuanced deiail in chapter 1 and the other chapters of l'art I. Ilowever, it, is usceful to repeat here its key features, albeit in stylized form, as an introducition to and reference point for what follows. The discussion focusses on the high growth era of the carly labos to the carly 19/0s. The main bank sysien is based on the special relationships

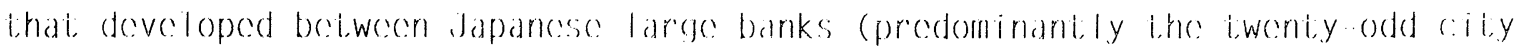
banks, irust banks, and long lerm credit, banks) and large industrial corporations, notably the looe or so then listed on thes stock exchanges. While: the ma in bank

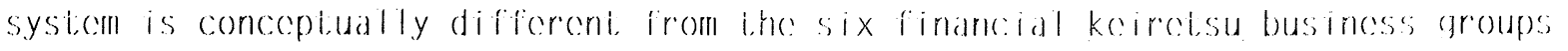
(Mitsubishi. Mitsui, Sumitome, Mai ichi, Iuyo, and Sanwa), in pracitice most of i,he main bank rolationships are with their banks or with the Industrial Bank of Japan. the largest of the three preivate lone term credit banks.

Relationships beiwecen bank and borrower are a general characieristic of banking in all countries, since repeated transactions and accumblated knowledge of borrower creditworthiness are always important. Ihe Japancese main bank systicm is a highly developed, more intechsive, ciloser and in coctiain other respects distinctive form; it can be regarded as ihe epitome of relationship banking. Ihe system was not a deliberate creation of special government; policy; it, was an institution which developed and evolved as an effective response to the costs of 


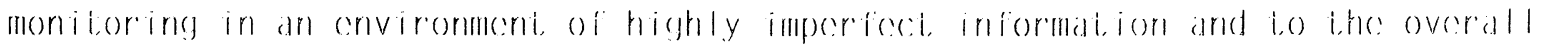
institutional framework and soti of governmeni, finarsial polscics.

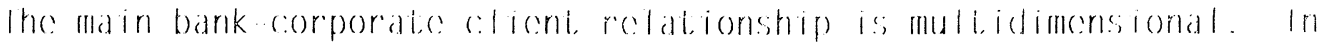

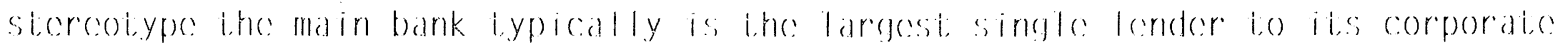

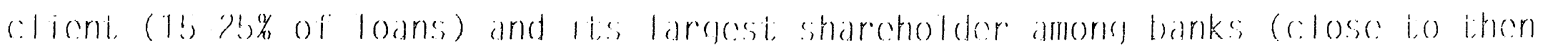

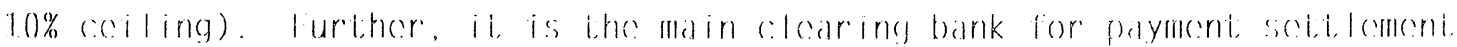

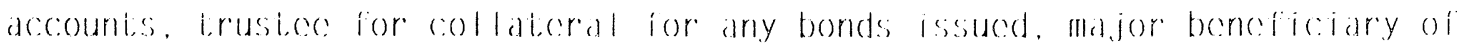

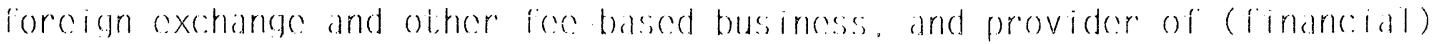

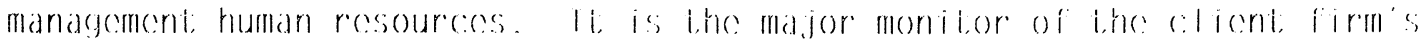

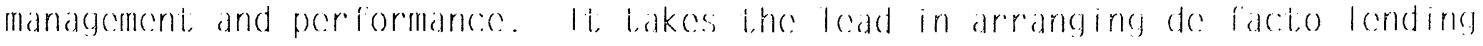
syndicales wilh olhor banks and financial insititulions for ils c:licnts.

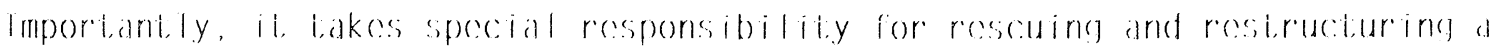

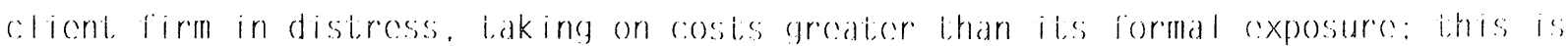
the most distinctive fodture of main bank funcitons. Unloss the situditon appears

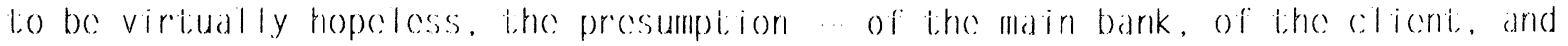
of the business, financial, and publis: polic:y communitios is lhat the main bank will rescue the firm through restruciureing or merger rather than liguidating it. these rolationships, arrangements, and commitimentis are based not on legal contracis but on a history of understiandings and expectialions, the build up of (invesiment in) trust, and repulational ceffecis.

Ihe ossches of the main bank sysicom has lain in ils sitrong information

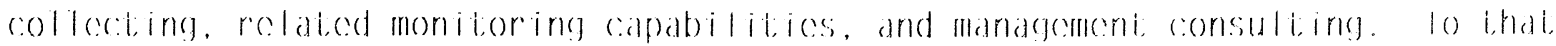

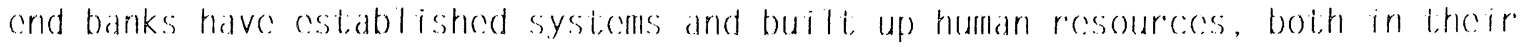
personnel system of permancent omploymenti, on the job tradining, and rotiation in assignments, and in the development, of special teams dedicaiced to mandge lihe rolalionship with cach major corporate cilicni. Monitoring is of course cosily. but the main bank did not direcily charge to cover the costs. Neither did it.

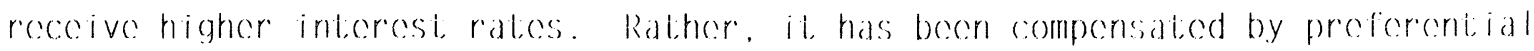

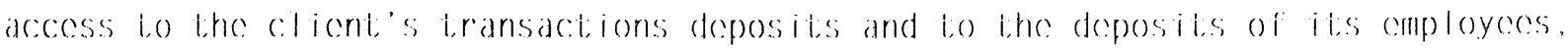
subsidiarios and subconteraciors, and preferential provision of foce servicess and

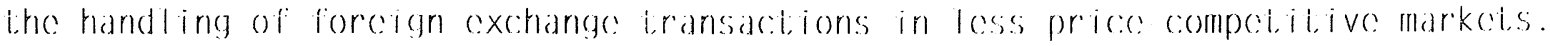

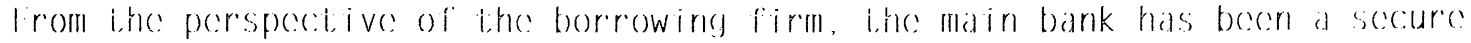
source of loans when coredit was i, ight, as it was most of the time during i,he high growith cra coven for large firms: a source of financial information and cxpertise: and a friend in limes of distross. The firm was propared to provide ilis main bank 


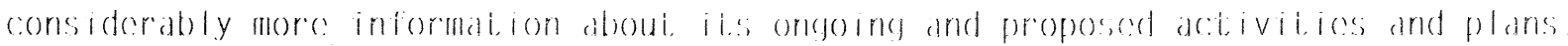

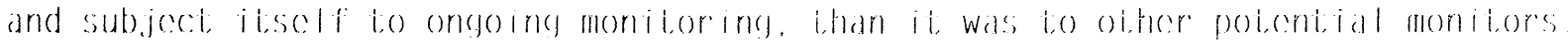

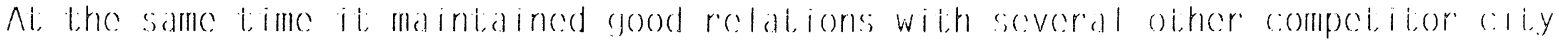

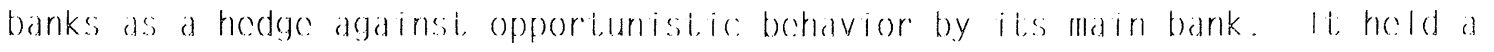

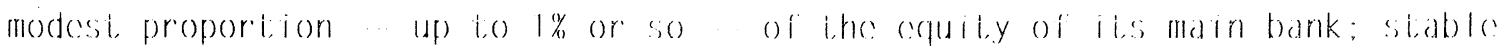
cross sharcholding solidified the rolationship and turned out to bo a good long

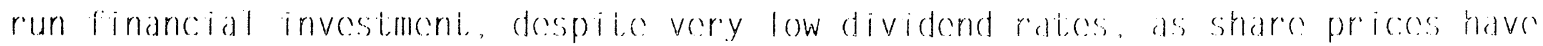

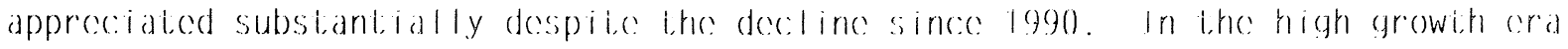

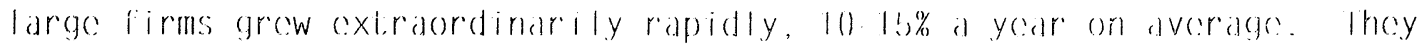

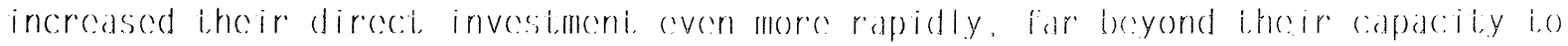

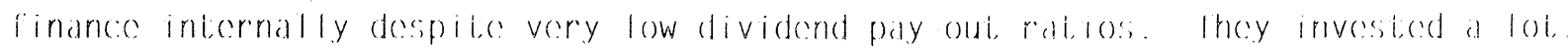

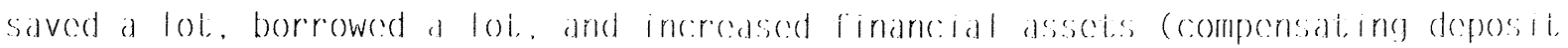

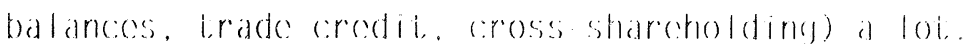

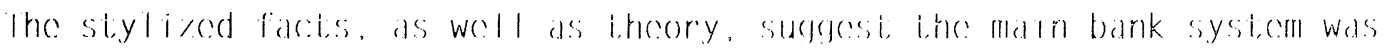

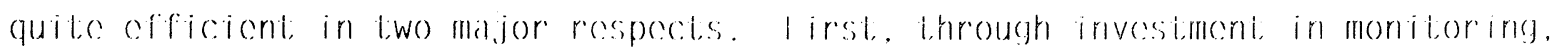
main banks were able io increase information and improve ceredit, covaluation. thercby reducing loan risk premia; and they probably improved corporatio managemeni. performance by providing incentives not lo shirk. Ihe main bank sysicom

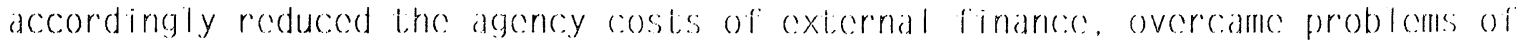
imperfoct information and its asymoctrie distribution, and made it possible for

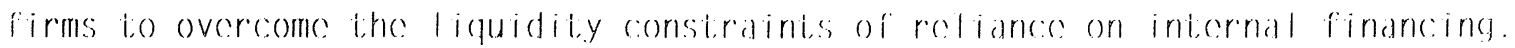
Ihe system conabled banks lo diversify portifolios by beine main banks for some:

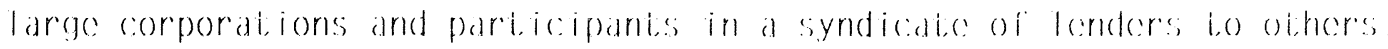

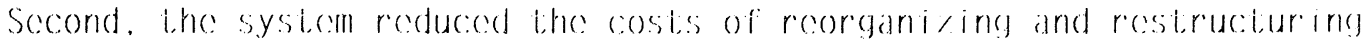

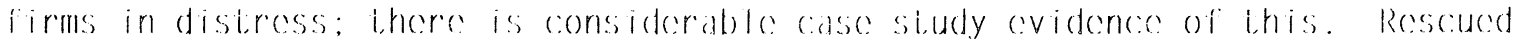

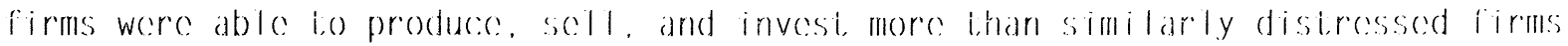
without a close main bank rolationship. Japancse costis of rosteruciuring large: firms were significantily lower l,han for distrossed American firms using the:

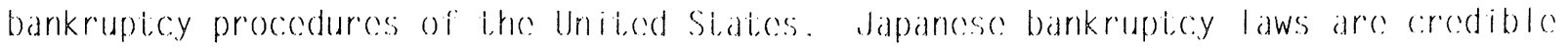
and relatively sirong, including removal of lop mandgement; ihe possibility of

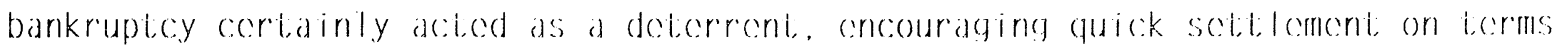
negolijaled with the main bank. In the high growith cra theres weres only a few

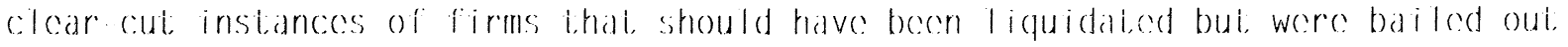
rofered to ds sofit budgeting problems or lype? corrors. 


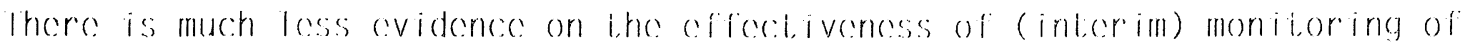

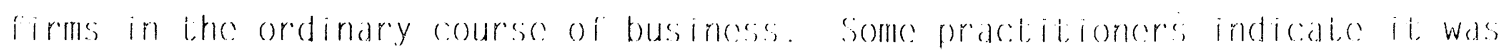

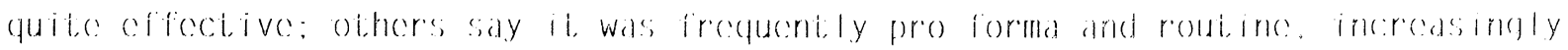

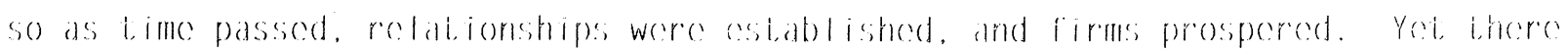

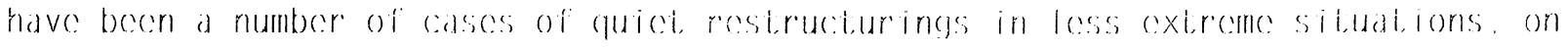

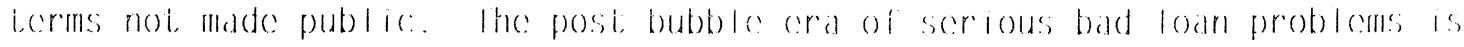

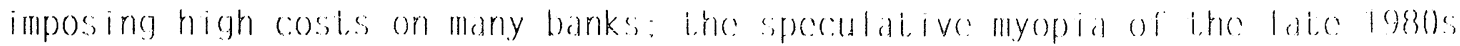

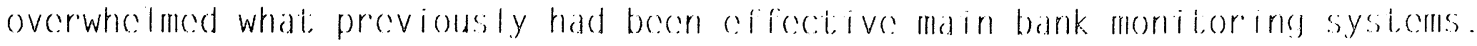

the Japancese ma in bank systern is not a panacea. It has weaknessess as well as strengths. Ihe main bank relationshipe is private and participants, not,

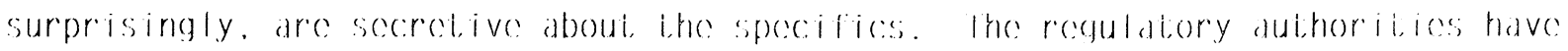
used administrative guidances and informal comrmumication with banks; the degrese of public: disclosure has becn limited. Ihe comy relationshipes beiwecn recgulators and banks were based on preferential acecess lo information and mulual t,rust, not io be

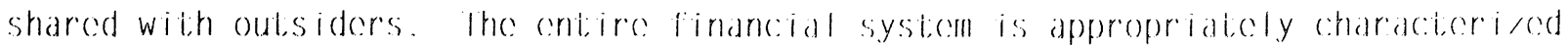

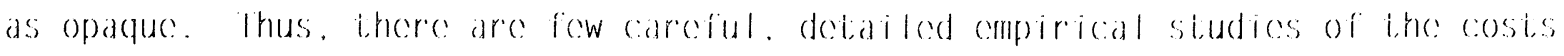
and benefitis of the ma in bank system.

$\wedge$ serious problem has becn the potential collusive cexcreise of oligopolistic market power by the large banks, botith as ma in banks and mores generally as financices of big business. The cevidence is mixed, bui it appears there was a substantial degrec of competition among the doecn or so city banks. Relationship banking provides insider access to information for lenders; ihe main bank system increased that decorece of aceoss and hences the possibilitices of exploitation for institutional or personal benefit. corrupt behavior in londing or other decisions by bankers or the regulating officials has becen the cxception. bespite some notable, indeced flamboyantly scandalous exceptions, ihere is litile cvidence that this was a serious problem overall. Ihe system was basically honcsi.

The most fundamental question is what kind of conomic system a country wants. The assumption here is that policymakers in developing market and transforming socialist, conomics, like Japancese, are commiticed to a predominanily 


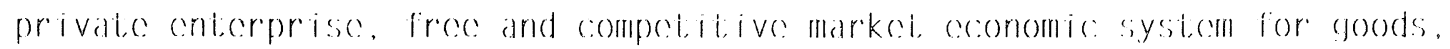

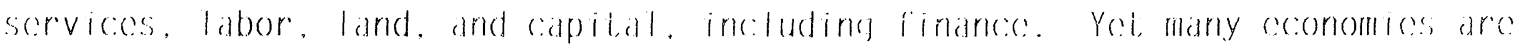

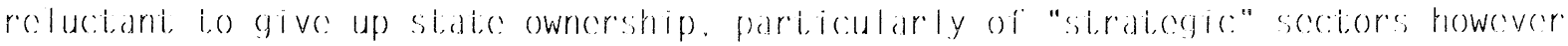

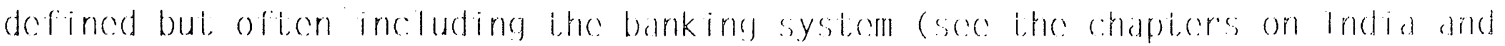
(hina). Ihis is a key issue for lsts, but has becen important in many developines market coconomies as woll (sece the chapderes on Korea and Mexiso).

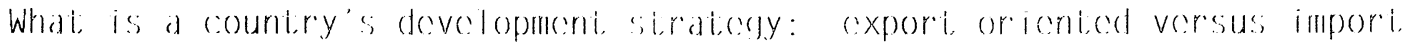

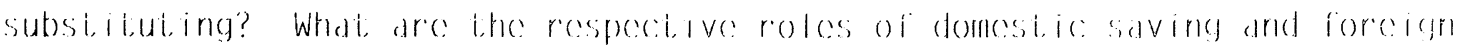
borrowing? What, is the nature and degrese of industirial poldey, however defined? An open ceonomy the free international flow of goods, servicess, and captital

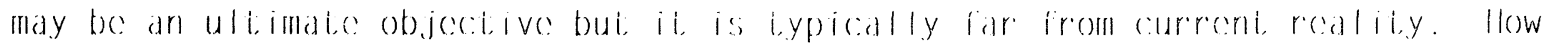

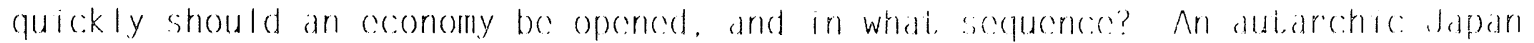

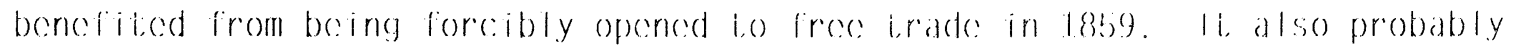
benciticed from import probecition and capital outilow rositricitions in the carly phases of the postiwar high arowith cra of rapid domestic: marketi cexpansion and government concouraged strong competition amone dapanese firms, many of them new critrantis.

Iwo further policy issues are of systemic importances lirst, macrocconomic: stability a cespecially reasonable price stability is cescential for lone offective and cfficsent funcitioning of a financial systesm and. while the cevidences is mixed, for overall ceonomic performances as well second, ihe cestablishment of instibitions to support, the market comomy particularly the legal systern and information systems of accounting, auditing, discolosure, and transparency is osscntial. Who monitors companies, banks, and otiher coonomic players, how, and how well? A contral theme of this book is that the main bank system of monitoring well met the necds for information prior to the costablishment; of adecquate information systerns. Ifforts to achicene macrocconomic stability, build the institutional support structure, and (recote financial institutions are likcly to be going on simuliancously, particularly in ists. Ihey ares all recquisiles for a good financial systicm.

2.1. Japan's leconomy and l inance in lihe High Cirowith I rad

Japanese coonomis: growith in lho iwo decades beginning in the carly 1950s

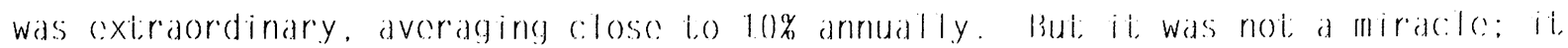




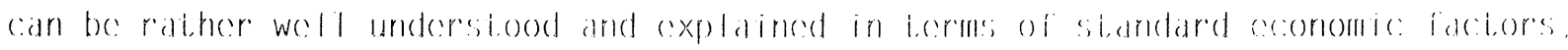

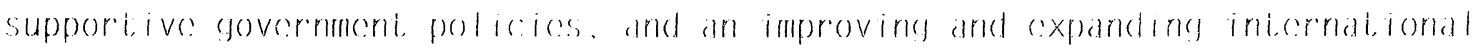

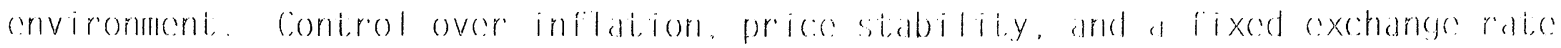

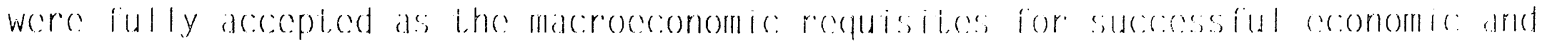

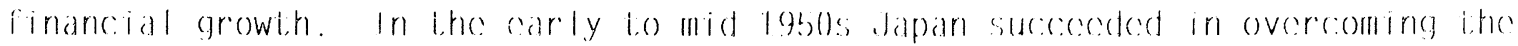
overwhelming coconomic problems of the carly postwar poriod: high inflation. shifi.

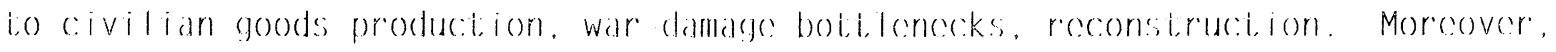

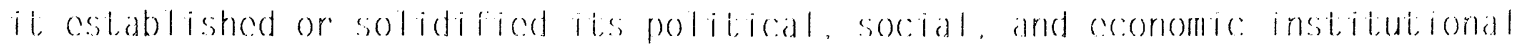

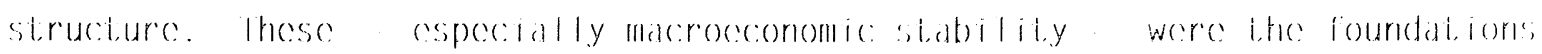
for the sustained spurti of rapid growlih, which ros one anticipated and in the carly

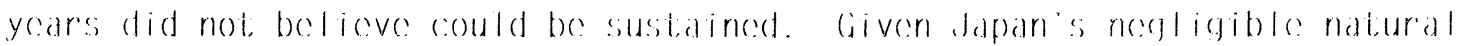

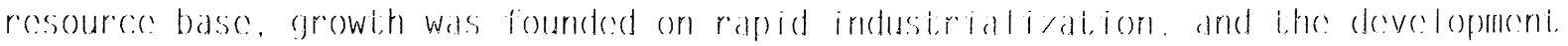

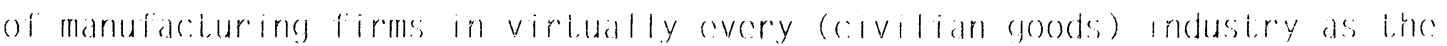

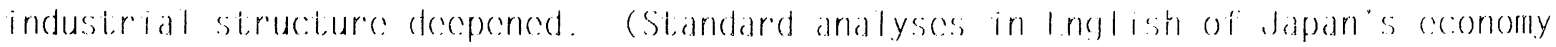
and ceonomic performance in iho high growih cra inc:lude l'alirick and Rosovsky (19/6), Nakamura (19831). Kosad (1986), and Yamamura and Yasuba (1983/).)

As surprising as it secms boday, Japan in the mide togoss was cilassified as a less developed country because of its low income per captiat it; graduated to developed country status only in logh. However Japan differed from other low

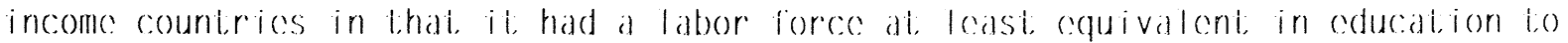

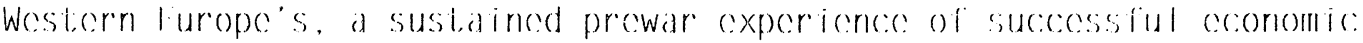
development, and substantial numbers of manderers, congincors, and icechnicians

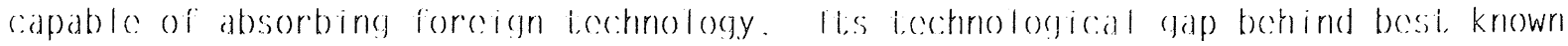

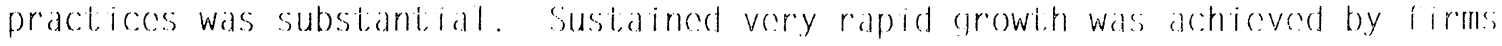

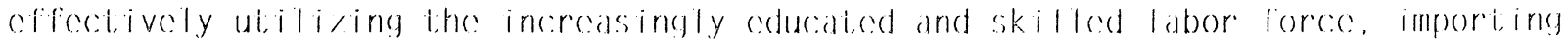

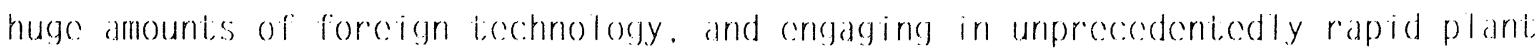
and cequipment, investment, in new, mores produci, ive capacitiy.

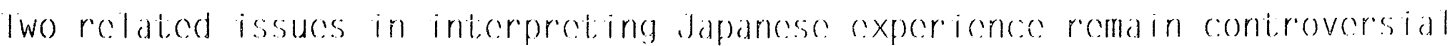
cven among specialists: wholher growith was sidio led or led by privalo

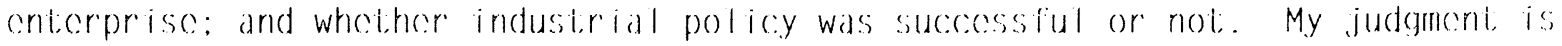

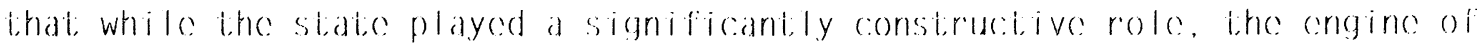

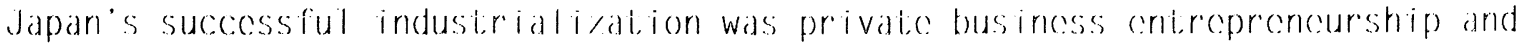
investment; without this, government, supporti and intervention would have becen incffective, if not counterproductive. Ihe results of industirial policy were

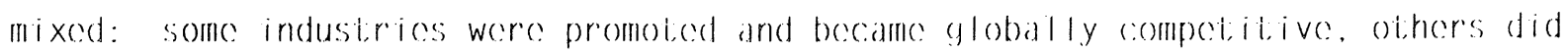


not; the success of many wimer indust.rices was due preimari ly to business

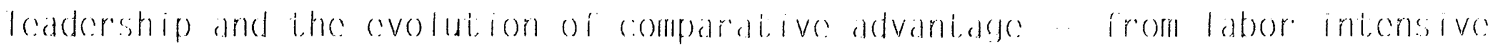

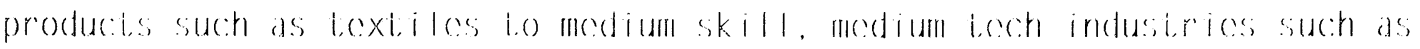

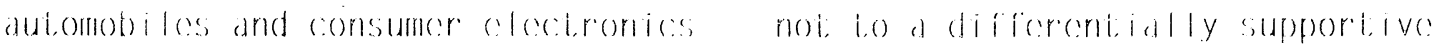

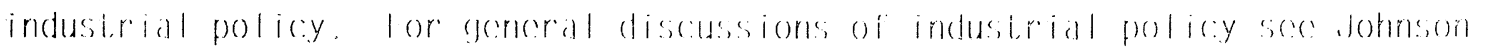

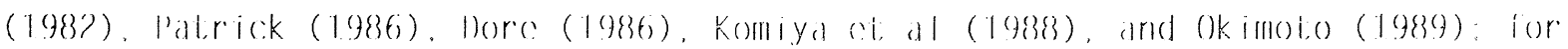

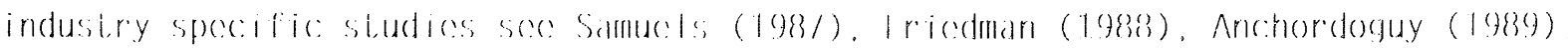
and cicrither $(1990))$

certainly the government, role was imporiani, It, pursued an invesiment

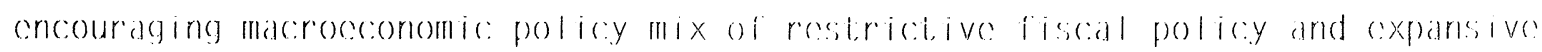

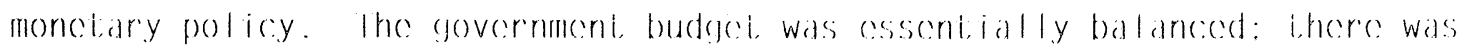

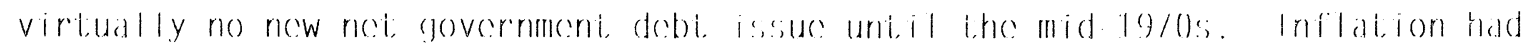

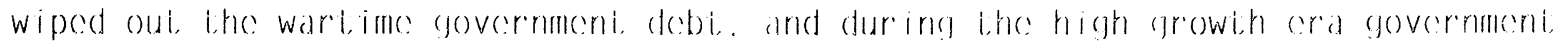
debi, as a share of cine was low. One by produci, was i.here was no scecondary markei. in Ircasury bills or Ionger ierme government; debt.

the government provided a supportive convironment for privale busineses

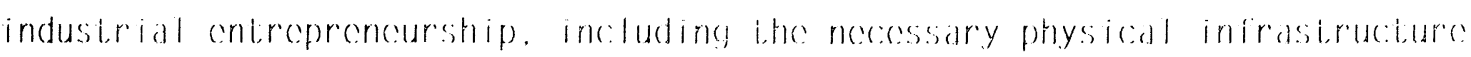

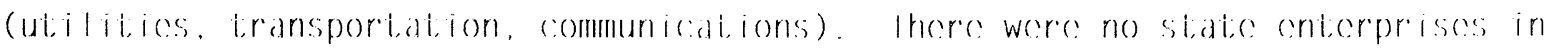
manufaciuring aside from cigarei,ies and ot.her i.obacese producis, a monopoly for

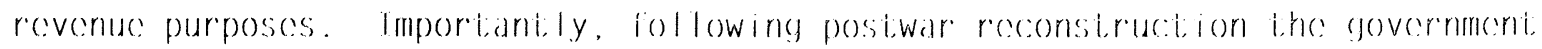

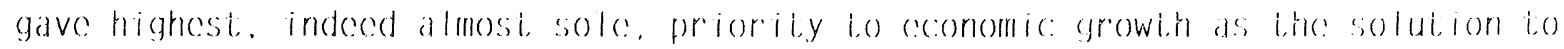

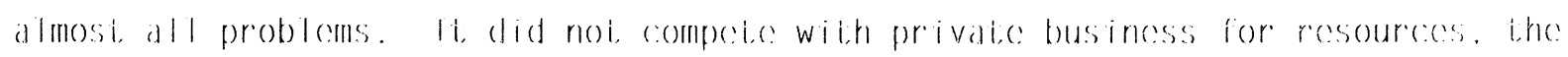

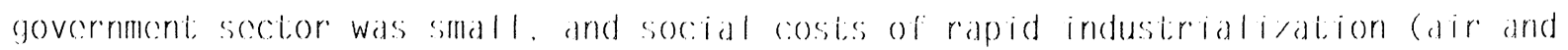
water pollui,ion, urban congesi,ion, lagging improvements in housing) were allowed

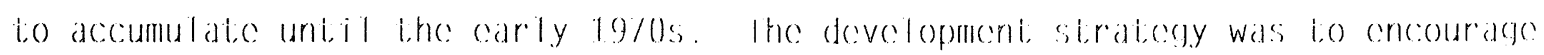

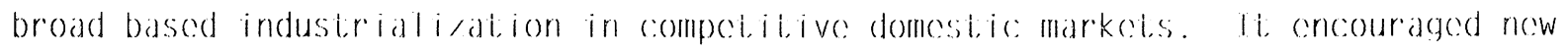
domesitic contry but continued the carly postiwar protection of industry against

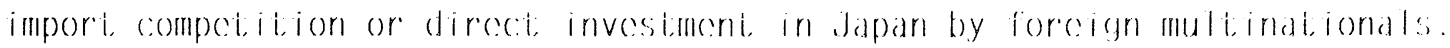

"Ixport and Save" was the slogan on a huge banner across the conitrance io

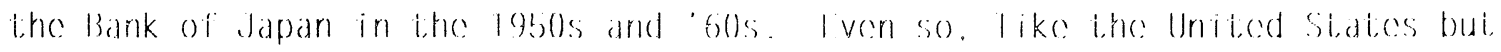
unlike most rapidly growing coonomices, Japancese postwar coonomis growith has becn

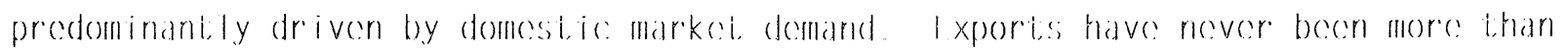

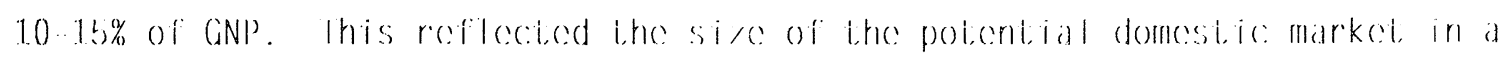
country whose population was iwice that of any western luropean country. Ni l,he same time, in the high growith cra importis of machinery, cquipment;, and raw 


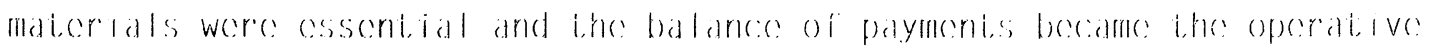

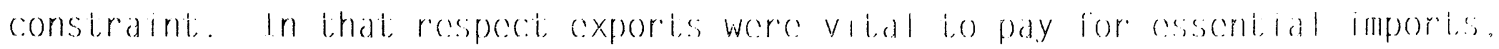

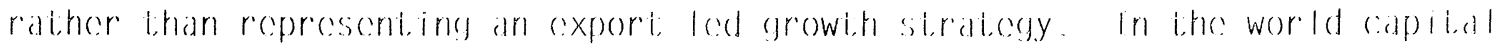

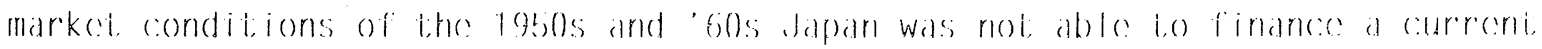

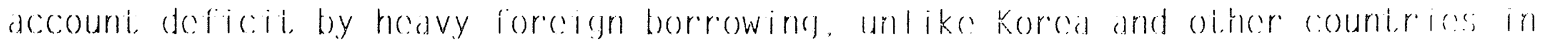
lithe $19 / 0$ s.

One of the most noteworthy foabures of dapan's sucecossful growith performance: was the tremendous imereases in houschold saving ds a share of family

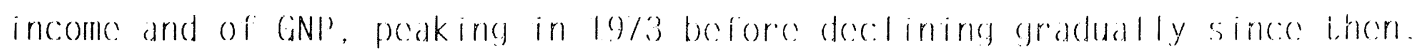

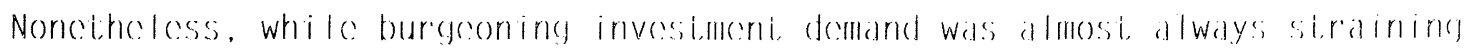

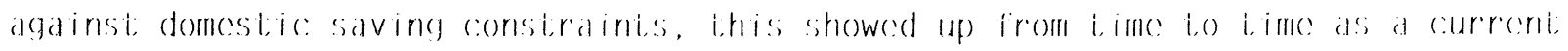

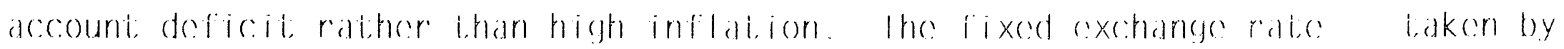

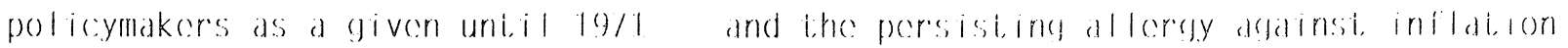
congendered by the carly positwar iramas made macroceonomis: contirol of inflation csscritial.

Rapid coonomis growlh was and is a virluous circile It justified, by making profitable, the rapid expansion of productive capacity by firms and gencrated demand for new projecis and producis. He incereased the value of new projects and investiment, in them. It meant that coven mareginal projecis were not; outright fallures; the instances of large firm bankruptecy or rosiruciureing wore rolatively fow and the costs limited. Many new small firms wore continuousily

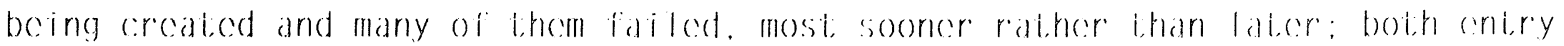

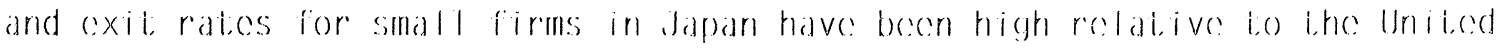
Siatos and other industrial couni,rics. Rapid growih gonerated high saving ratios by houscholds and corporations. It gencrated rapid incercasces in real wages, and consumption, thereby providing a social rationale for low interosi, rates on saving

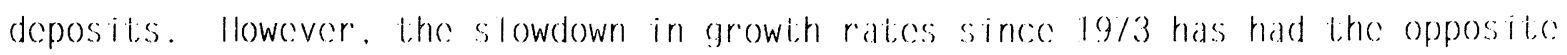
offects. Over time firms prospered, grew more powerful and compelibive, and becane incroasingly independent of government influchece dapan's cxport success.

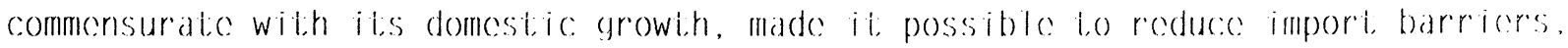
and over lime that has laken place. albeil primarily in manufactures and loo a significant degres in response io foreign pressures. 


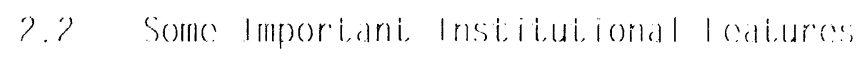

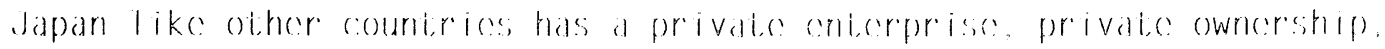

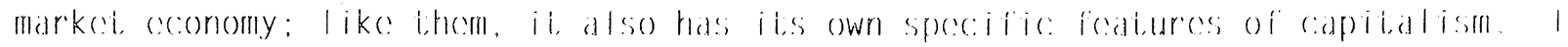

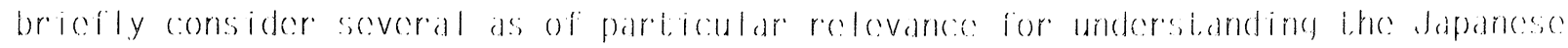

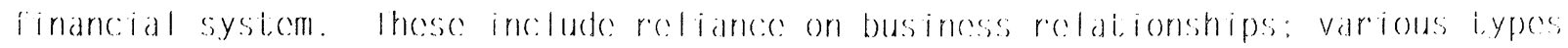

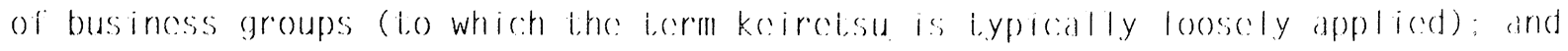
the high quality of the centeral government burcaduradey, coppecially ihose concouraging, supervising, and recoulatime ihe financial system.

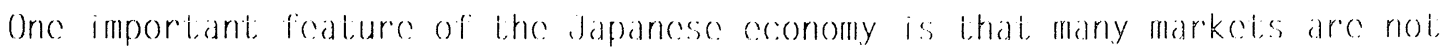
imporsonal. arms length, spot markeds. Ihey are moderabed by roladionshipes among

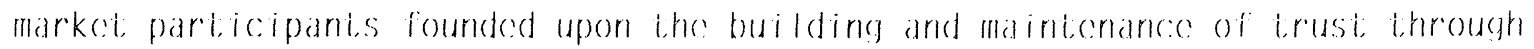

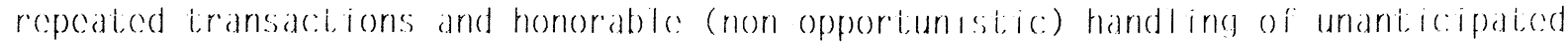

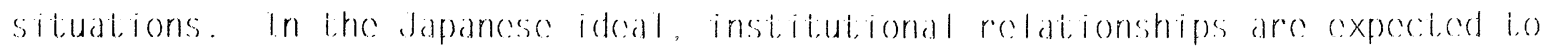

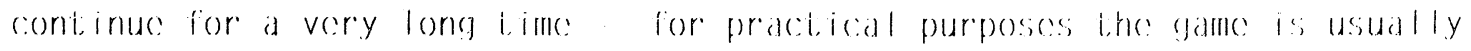
assumed to go on forever. Relationships are multidimensional, complex, and subtily

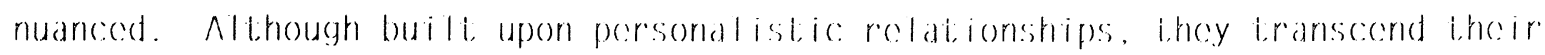
implementation by specific: individuals represcentines the partincers.

Rolationships are reflected in labor markets, subcontracting, buycres and supplicrs, brand loyaliy, and in banking, colitomiecd in the main bank system, as

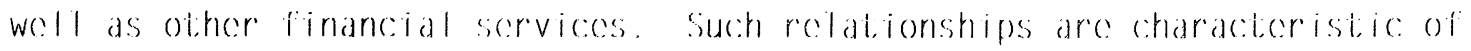
business in all coonomics, so the matier is one of degrece not of kind. Il is

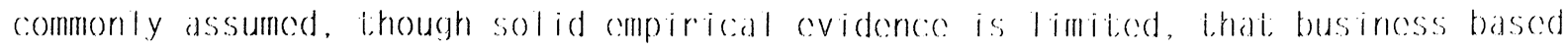
on rolationship arrangements and noliworks is mors cxicensive and intensive in dapan lhan in the United Sialos.

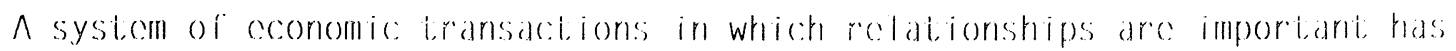

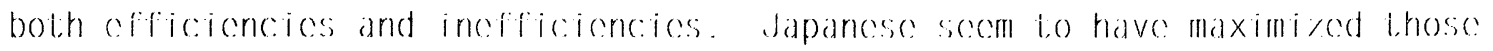

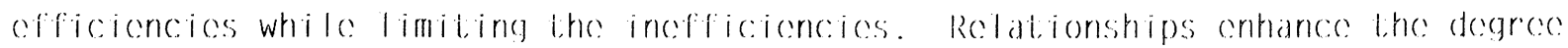
and reduce ihe cost of aceoss to information and monitoring. Relationships

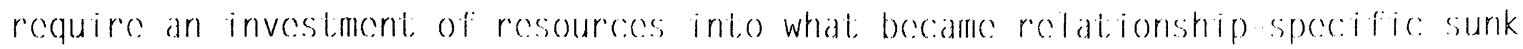

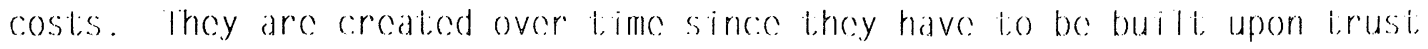
congendered by repeaded experience: trustis is condilional upon the behavior and performance of the partiners. The payoft is that relationships increase the return on rolationship specific: investiments (such as subcontractors dosigning an auto part for a particular modol, or a main bank loan) by chancing confidence that lihe 


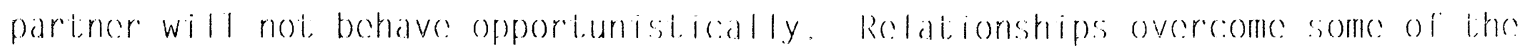

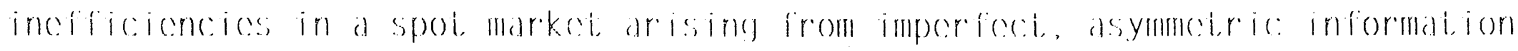

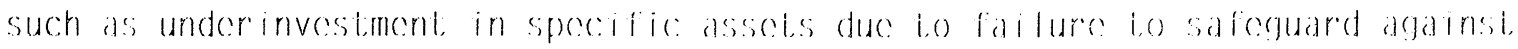

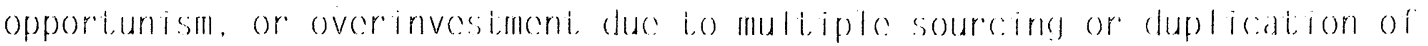

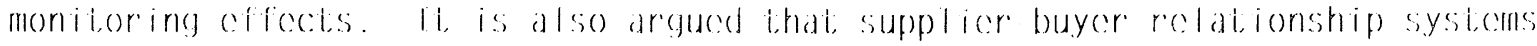

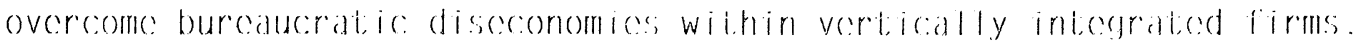

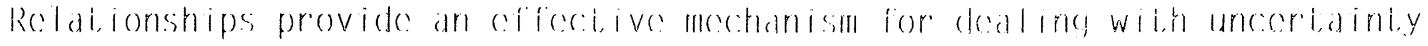

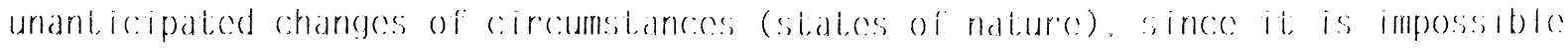

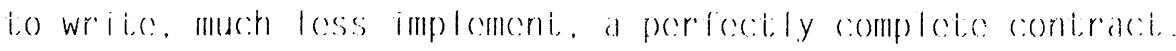

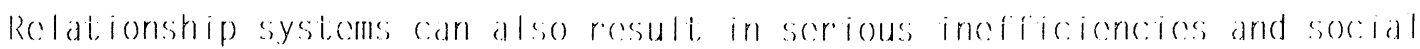

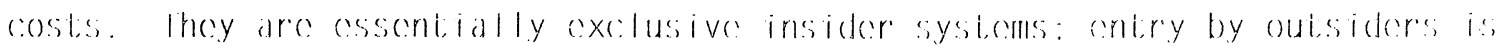

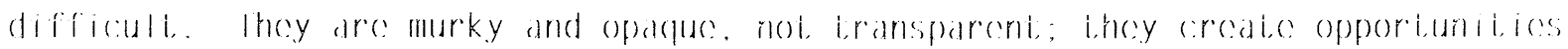
for fraud and abuso of power. A rolationship systom is subjeci, to porsonalistic:

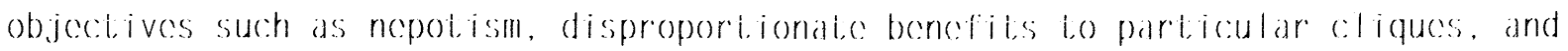

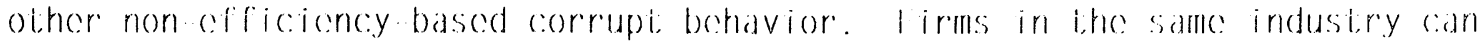
cstiablish rolationships, often i.hrough industry associations, lo crgage in oligopolistic or carlol type behavior. Th is difficult lo terminalo. rolationships: reciprocal obligations buili up over lime may resuli, in lypo? crrors (continuation of supporti woll beyond rational assossments).

In many soceicitios the social costs of rolationship systems far outwoigh

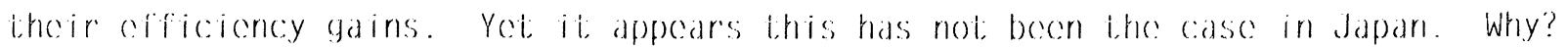

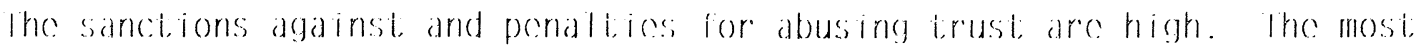

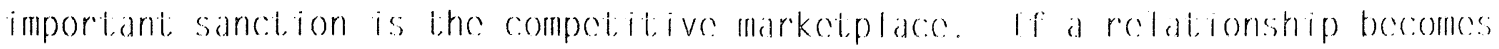

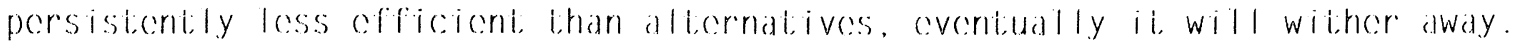
The discipline of the marketplase is reinforect by the competititive, ambitious drive of many dapancese individuals and institiutions. The inceritive systern rewards good performance and makes poor porformance cmbarrassing and shameful, as woll as coonomically costly. Ihose porceived as not; living up io i.ho obligations of cxisting rolationships suffer ircmendous loss of reputation, making them loss

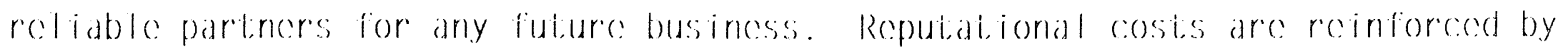
the high value placed upon siatius

Many Japancese apparenily approach relationships conditionally, with a

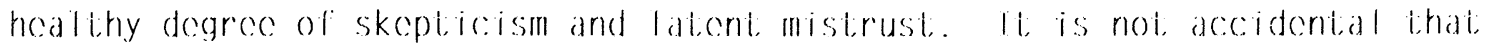
companics simuliancously scok a main bank rolationship and in aggrogatio borrow most of their loans from other, frecpucrity compcititor, financial instibutions. 


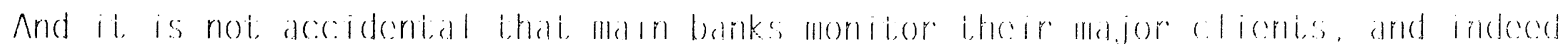

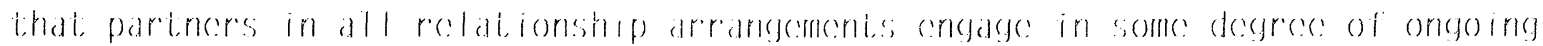

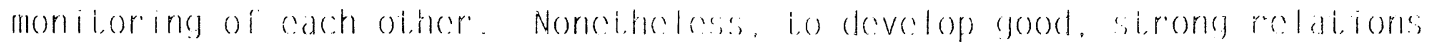

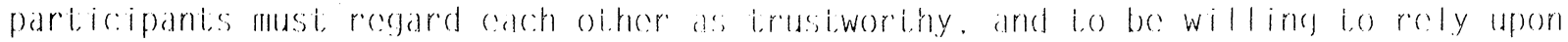

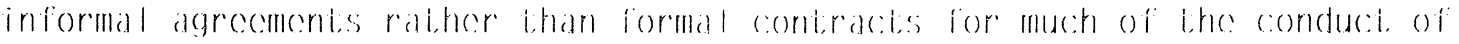

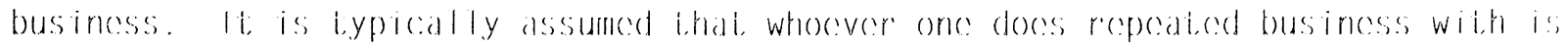

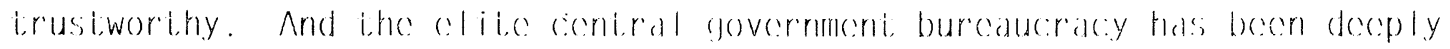
lirusted, al Icasi until recomily

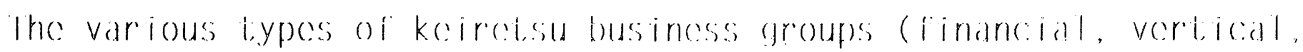

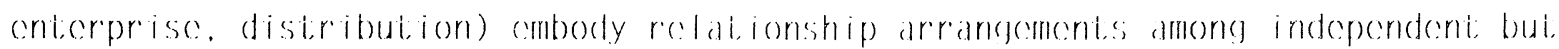

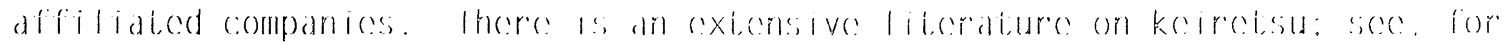

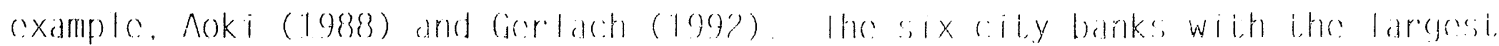

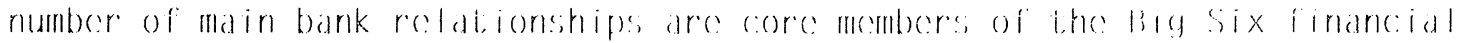

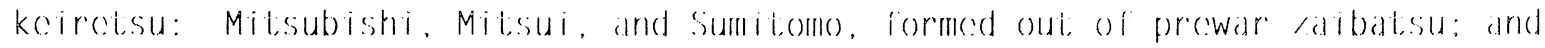

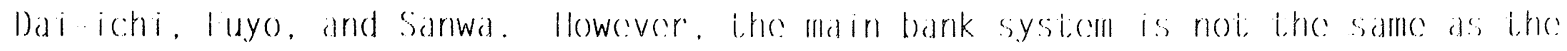
Big Six keirotsu; obther large banks also have main bank rolationships. In particular, the Industrial bank of dapan, the largest, lone locrm credit, bank, has had as many main bank rolationships with l isted companiess as liho average big fo city banks; with its own business group of affiliated companices, it, must bes included as a major playcre in the main bank sysicen (sce the chapler by pacher)

While all core mombers of d particular financeial business group have the: momber bank as their main bank. Lhe bank also has a main bank rolationship with other large firms and. ihrough the syndicadion processs, ihe firms ofien borrow

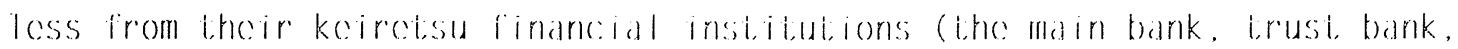
insurance companies) than they do from non mombers. While there may be: bencefits

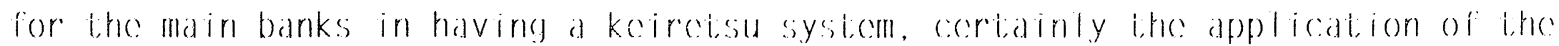

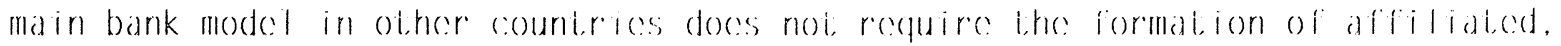
autonomous ly mandged, groups of businoss firms.

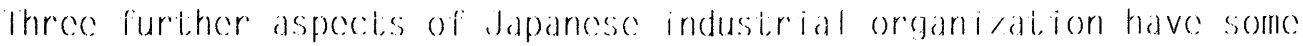
rolevance for lihe operation of the main bank system. first., stock ownership in

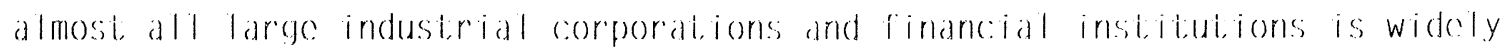
dispersed; ownership is separated from control which, in normal circumstiances, is excreised by a solf porpeluating autonomous profossional managementi. Mandgement:'s stated goals are to boncifie all its siakcholders, including importiantily ilis workers, not; simply i.o maximise shareholder value. Corpordie governance is 


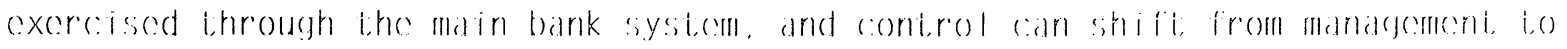

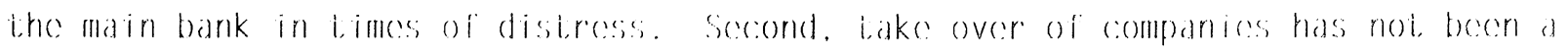

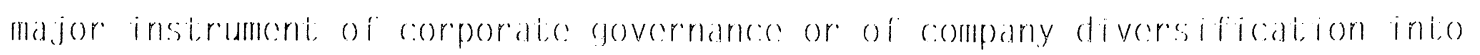

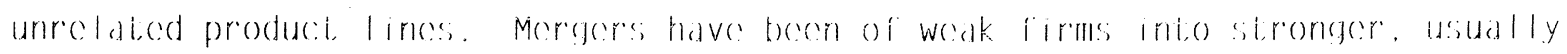

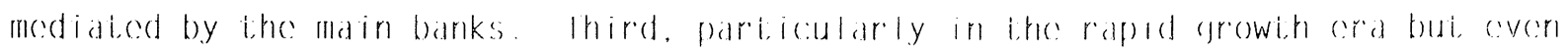

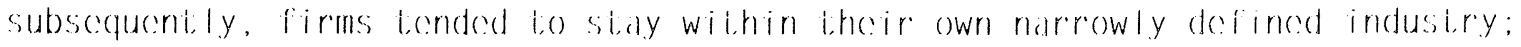

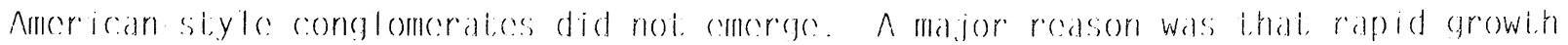

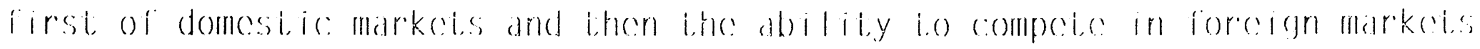

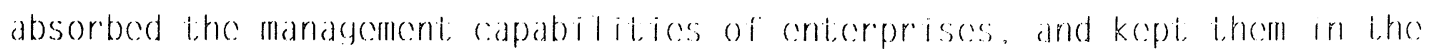
indusitrios lhoy know besit.

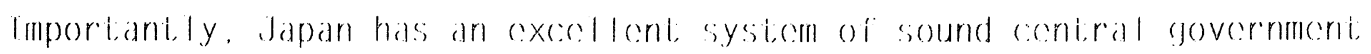

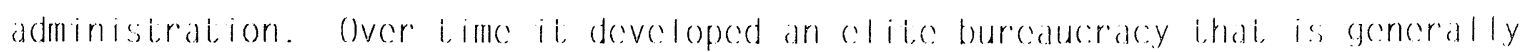

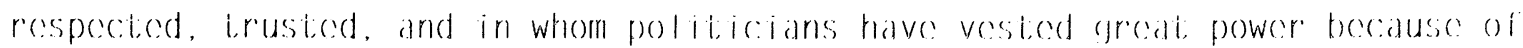
their prosumed capability, honesty, and identificalion with the nationd interosi. Cor at least cach Ministry's avowed perception of the national intorosi). Ihose:

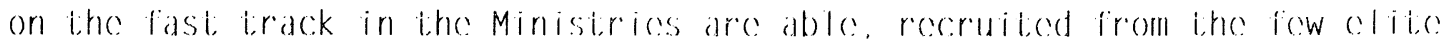
universilices, and promoled from wilhin; only the Minister and parliameniary Vices Minister are outsider, political appoimimentis. 12

Ne the apex is the Ministiry of linanses which, among other rosponsibilitics (such as making the budgel and designing and implement,ing tho lax system) oversecs, promotos, guides, and supervisos, and obhorwise costablishos and monitore; the rules of the game for the financial system, and cespecially lihe banking sysicom. Irust and confidence in the Ministry of l inances and other ceonomic ministiry burcaucrats have had important, implicalions for the financial sysicom, cespecially

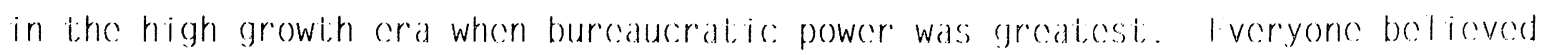
that the Ministry of linance and Bank of Japan guaranteced bank safoly. Ciose supervision (monitoring) would proveni, mismanagement, oxcossive rask liaking, fraud. The sysiem was belioved in even lihough it, was opdefue and governmeni. officials have relied on administiditive guidance rather than law in composing and

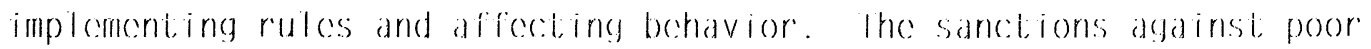
performance, much loses corrupt behavior, by government, of ficeials were severo:

7. Soe the papers prepared for the World Bank Workshop on the Rolos of the Civil

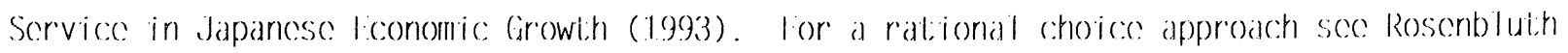
(19839) and Ramscycer and Roscribluith (1993). 


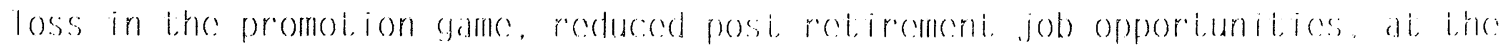

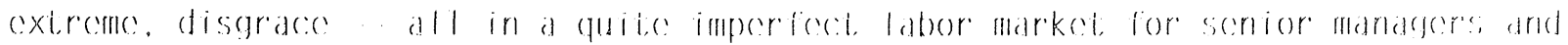
government, officials.

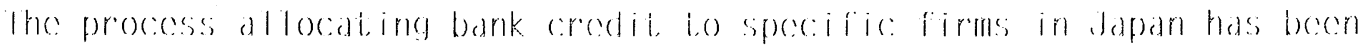

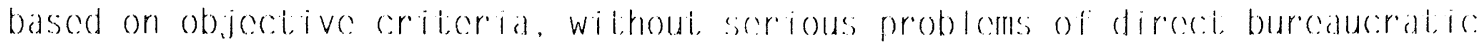
intervention. Known instiansess of direcit bribery and corruption of government.

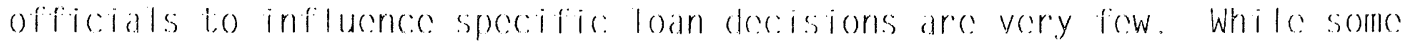

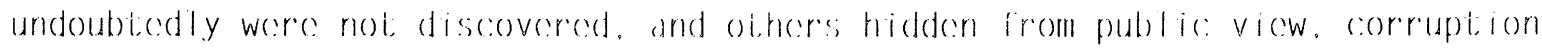

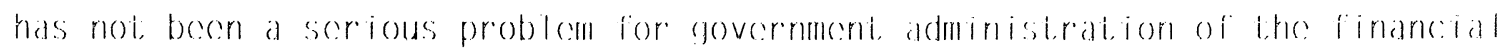

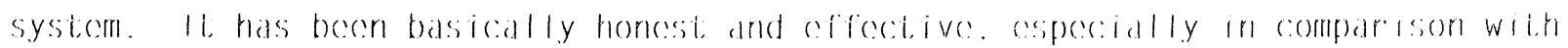
many developing marketi cooremios and lsts.

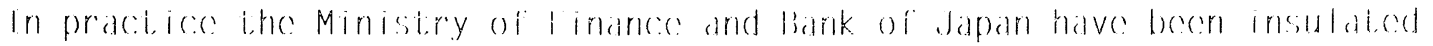

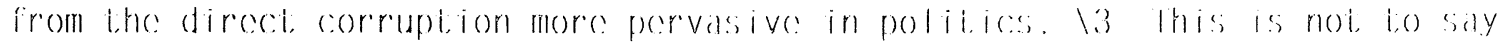

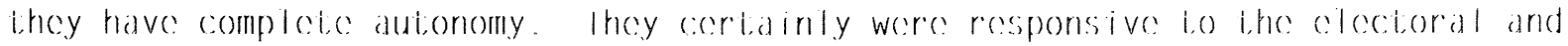
other necds of the l iberal locmocralic: l'arty politicians in power; the "iren triangle" of cosy, mutually supporitive, and bencificial big business (including

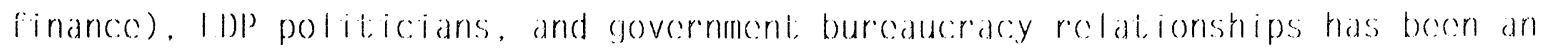
important reality. As in covery country, Japancese banks have had a sitrones vosided interest, in shaping the reguldtory system and government; financial policics loo their bencfit. Ihoir relationships were based on goneral supporti of the system,

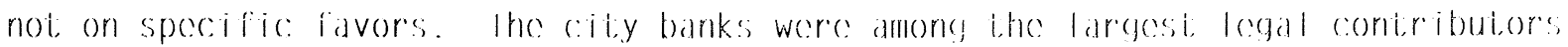

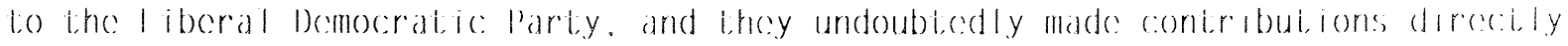
io individual political lodders as woll.

3 lo be colected and stay in office, politicians have had to maintain and sometow pay

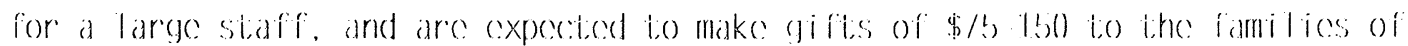

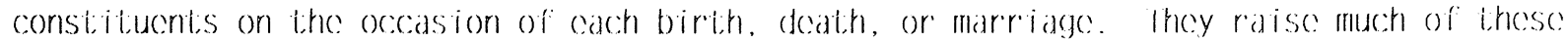

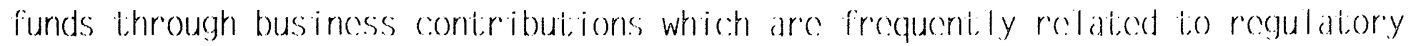
rostrictions (such as the Sagawd trucking licconse scandal), government purchasces (notiab)ly

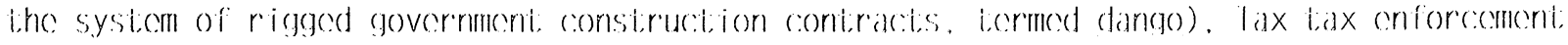

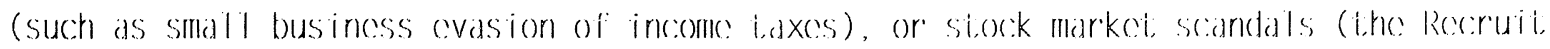
case). Ihat these arrangementes are generally tolerated so long as lifoy stay within limits suggests a series of impliciti social compacis, which can only be addrossed through comprehensive political reform. 


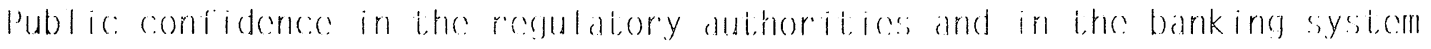

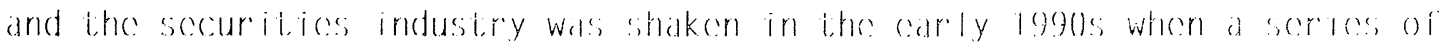

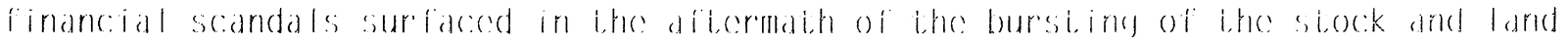

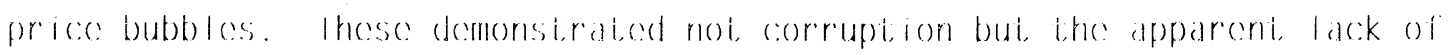

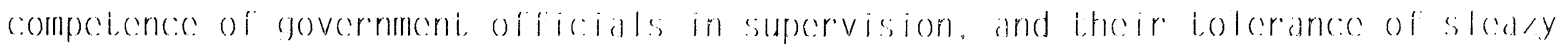
if not outrighi illegal praci,ices as interem measures in the procoss of financial

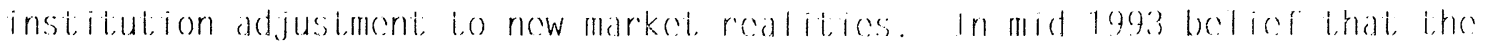

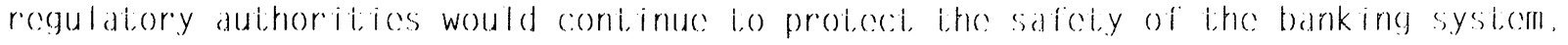
and cespecially deposilors, remaimed sitrong bui, was more conditional than before: a fow small banks i,houghi, io be in particular dificiolity coven had considerable deposit, withdrawals.

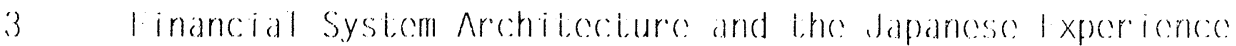

The government desiegns the architeciure of the financial system; the market, gives its substances, fills its halls, and coven alteres the design it.solf Covernment policy ostablishos ihe framework whereby systecol stabilitiy is maintained, and determines whether competition in financial markeds flourishes or is cmasculated. lo the exicnt that market forces predominate, they bring about, changes in structure as new financial marketis, instirument.s, and institidions

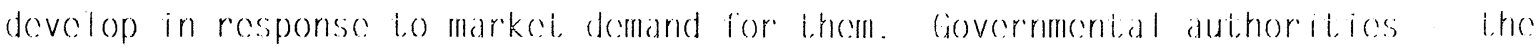
ministry of finance, contral bank, financial insibitui,ion supervisors play a major role. Ne the micro level they oversec banks and other financial institulions with prudential recgulation and supervision. But they do far more than that. They build and modi ify the institutional situcture and hence the? industrial organization of finance: ihey set and chereres the rules of the garne. Japancese policymakers in the carly 19t,0s had to address the same issues of financial system structure and policy facing developine market coonomices and ists

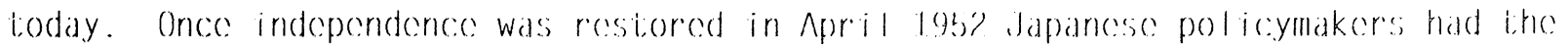
frecedom to alter, amend, or accept, the cxisting structure, to create new institutions, and in particular to implement their own financial policics. Ihis scction addrosses important issues of financial structure and policy for developing market coonomices and ISts, and discusses how Japancese pol icymakers and decision makers, public and private, have deali, with them. Ihese include banking 
basced financial systems: universal versus commersial bank systems: bank safoly:

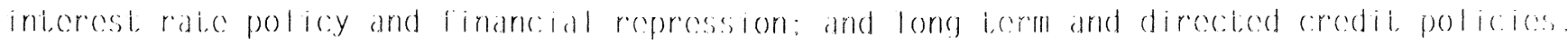

3.1. Banking and Sccurition Markci,s

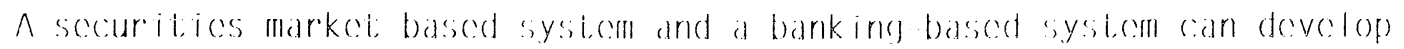

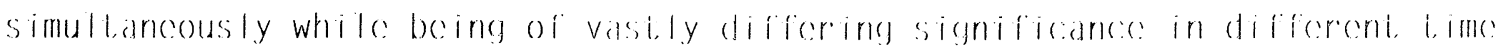

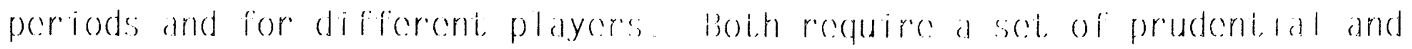

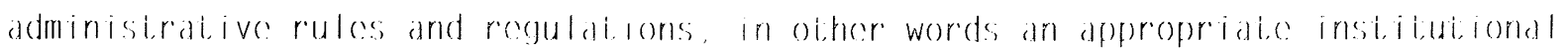
structure and administrative framework, in order to funci,ion cefoced,ively and

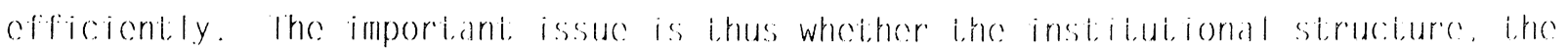

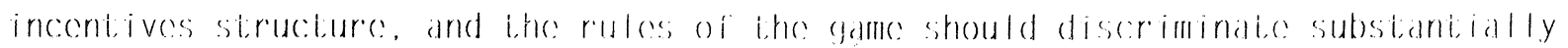

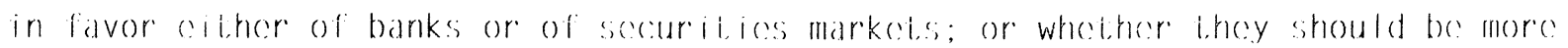

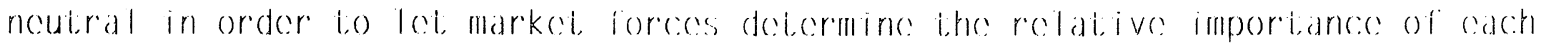
over lime.

As a practical maticer, until a late stage of conomic development, sccuritices markets will not be the dominant soures of business external finance for the corporate sector as a whole or probably even for larege firms. Which financial institutions can most clfeceively and officicntly monitor borroweres is

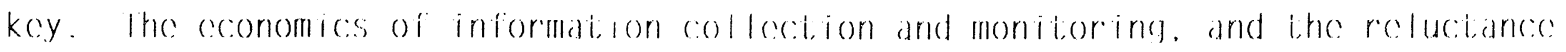

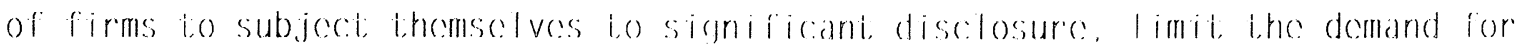

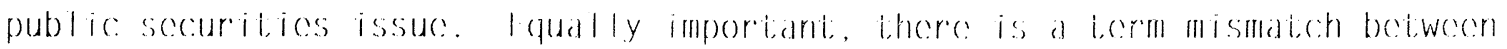
savers and investors; in relatively low income: countiries few individual savers are willing to lake on the risks of impersonal sccuritios investimentis or to make long tocrm commitmonts in financial asscts. Ihe risks are correctily percesived as higher in countries with recont expericnecs of inflation or substantial degreces of socio political as woll as conomic: uncertainty.

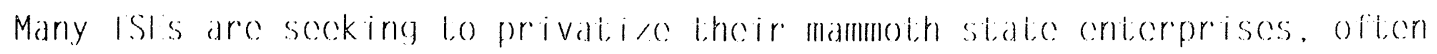
by widespread distribution of equity to individuals at low pricess. Such programs will almost incvilably, and desirably. lead to the cercabion of stock markets to facilitate changes in ownership of the: outstanding shares. Ihat can have important, advantages, such as increasing pressure i.o create adequate information systems and transparcency and providing market determined pricen information (signals) aboui yiclds and valuations. However. in ihe absences of overwhelming (and costily) incontives, it, is unl ikely that scouritices markets in Isls will 


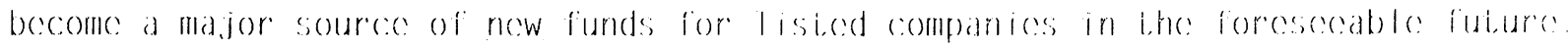

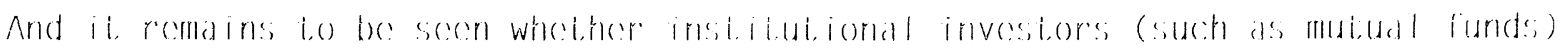

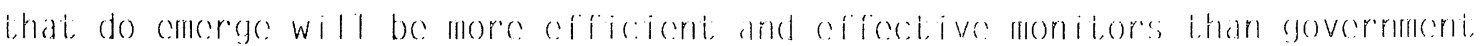
burcaucrats (probably so) or bank managers (uncilcar).

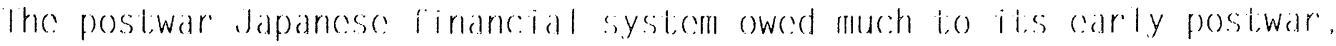
wartime, and prewar instiblutional herritage. Ihe Ministiry of le inances opted for a system of bank loan based finance for indusirial corporations. Ii, used recjulatory

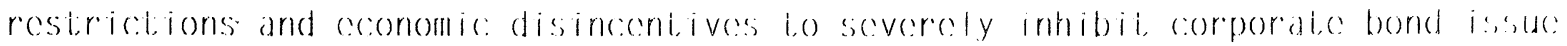
and the development of a sccondary market, (sce the Ramscyer chapter). I sscontially

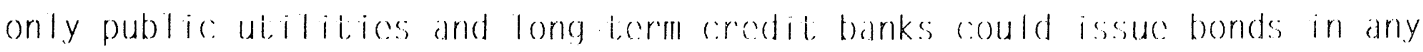

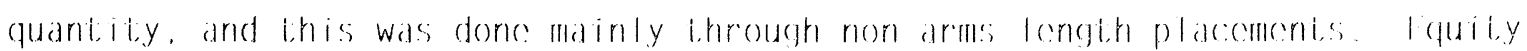

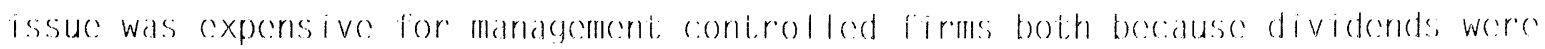
paid out of after lax profitis while interesit paymentes were a deducitible exponse: and because the prewar custom of new si,ock issuse at par rather than market, prevailed (well into the 19/0s). Ihe issuance of commercial paper for short lerem finance was not allowed until 1983/. Rusiness, growing rapidly and always in neced of new loans for working capital and fixed investiment, had no choico but lo borrow from banks.

The basic rationale for Japanese policymaker discrimination in favor of bank finance over corporate bond or cequity issue lay in their perception that, savers in the carly postiwar period wanted safo, liquid, short lorm financial assets. The inflationary expericnese was loo traumatic: and recent; financial and real wealth was low and relatively cequally distributed i,he siock market had difficulty absorbing the shares relcased through the dabalisu dissolution procaram. Morcover, only banks had bond underwriting expericnes and experitisc from prewar.

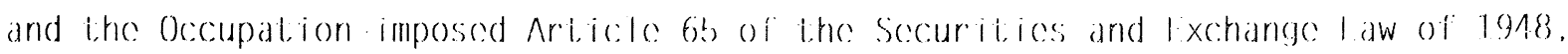
based on the American cilass Sicadgall Mei, separated banking and underwriting or dealing in securities. Only in the 19/0s and 30 s were the restirictions on corporate bond issue substantially cased, considerably tater than was desirable. Noncitheless, those policies were an essential component; of building a sirong banking system during lihe rapid growith cra.

\subsection{Banking System Structure:}




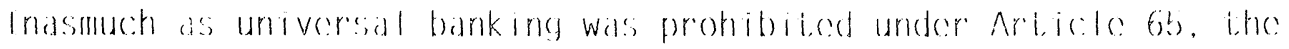

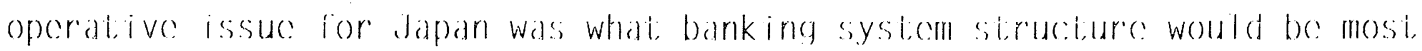

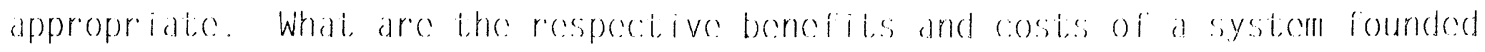
premarily on nationwide branch banks or on lareger mumberes of locad and reagional

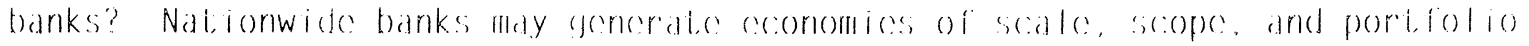

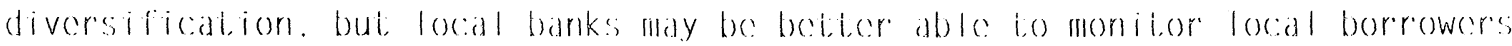

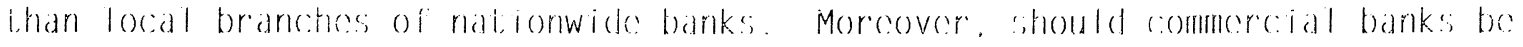

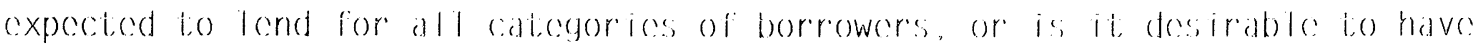

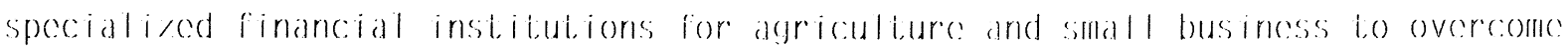

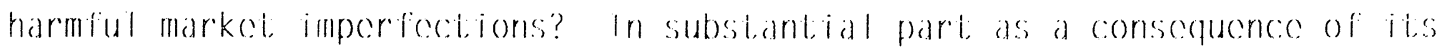

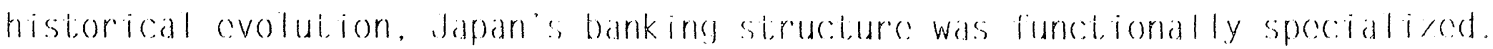

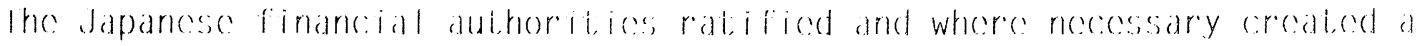
system of specialized finansial instibutions and seymented financial markats. In the domen or so malionwide ciliy banks, including the subscit of six major main banks. were to provide short, tecrm and lo some cextent, longer term loans to big businoss. Iocal banks, mutual savings banks, and credit associations weres to lend to medium and small firms. Agricali,ural cooperatives lent i,o farmers. the seven trust banks financed commercial roal cestatio and industirial projeciss with

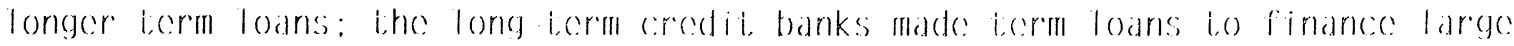
criterprise fixed investiment. Ihe government csiablished and owned financial instibutions lo finance priority acidivitics. Ihe laregest and most important in

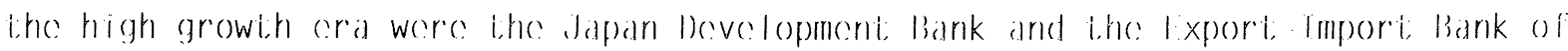
Japan.

The lair Irade Act of $191 /$ sce a b\% limil on dapancse bank ownership of a company's shares, in contrast to the prohibition of ownership in US law and lJK custom. However, once independence was restored the authoritices amended the law,

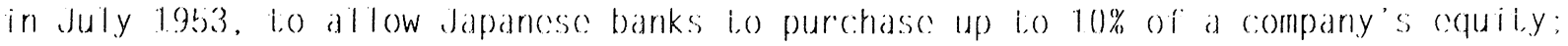

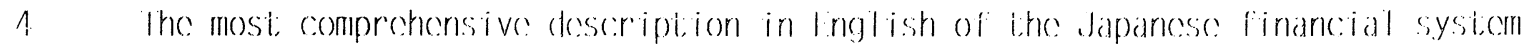

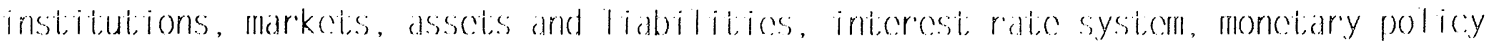
has becen propared by the Bank of Japan and appears in Suzuki (1983/). Iheres are a number of good andalyses available of the high growth era and of the subsecpucrit period of deregulation, including the chapter by llamada and lloriucthi in Yamamura and Yasuba (1983/). chapters by loranishi, and Kurosawa and Kiladgawa, in Patrick and Park (1ggh), Cargill and Royamid (1.98383), and Suruki (19830) and 19836). 


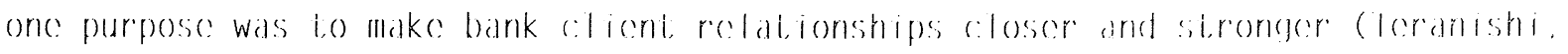

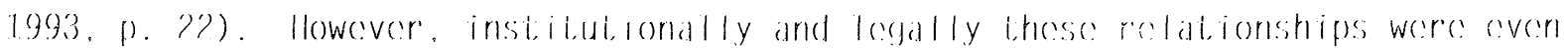

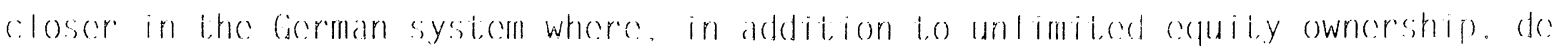

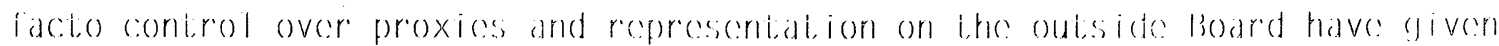
Corman banks what are conventionally vicwed as substantially grodicr powers. though batums argues should poweres were limiled l,o a relatively small number of firms and were not really exercised (sece the chapter on Germany).

the predominani, soures of funds for the financial syseden was depositis. particularly the saving depositis of houscholds as heneir saving rates roses dramatically and theres weres few safe alternative financial desedes. I ven

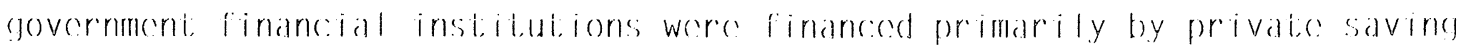

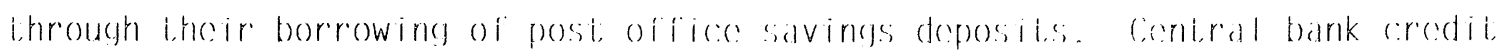

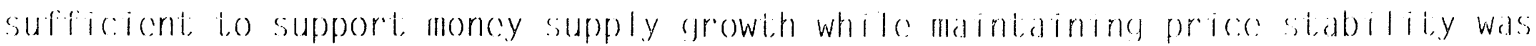
provided through cheap loans and discounts to lihe cit.y banks (more or less in proportion lo their sies), which in turn lont, lo large busincesses or lo finance cxportis, and purchased (on an allocated basis) bonds issued by the long torm credit banks, clectiric: power companies and other wi,ilitics, and the small number of qualified corporate clicents. listablishment; of new bank branches was profitable since deposit interest rates were kept artificially low while the demand for loans was high. The Ministry of linance controlled i,he number and allocation of branches, and used that ds an incecntive devices to consure bank compl iance with it,s guidances. Saving was more widely dispersed geographically than large contererprise fixcd investment, and the inter bank call market, in which ciliy banks borrewed substantially and persisticntily. reduced discequilibria in the segmented deposit. and loan markots.

3.3 Banking System Safoly and Siabilitiy

$\Lambda$ basic: issue, which cortadinly has shaped dapanose policymakcrs thinking, is how to maintain the safety and stability of the banking systerm. To what cextent. and how should depositors be proteceted? Should individual banks be allowed bo fail? How can the moral hazard of cxcossive risk iaking by banks be overcome? lo

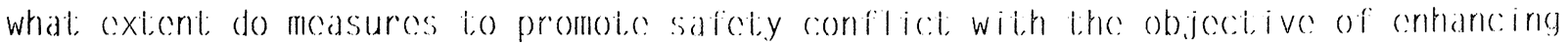

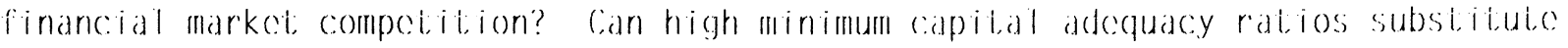
for government guaranteces in protociting depositors? Ihose are major questions 


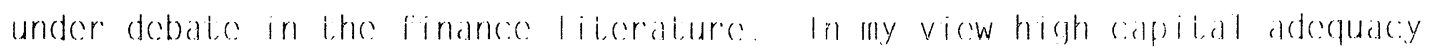

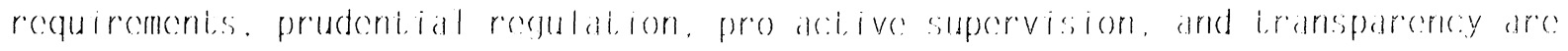

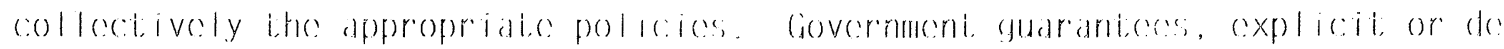

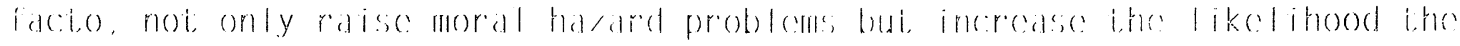

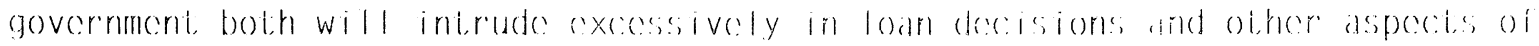

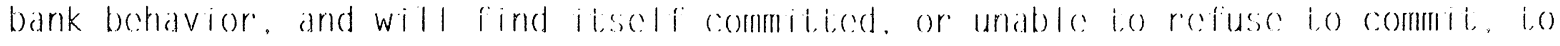

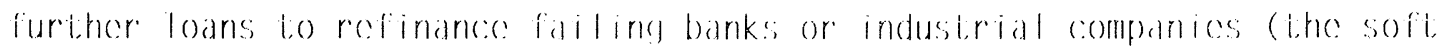
budgeting problem

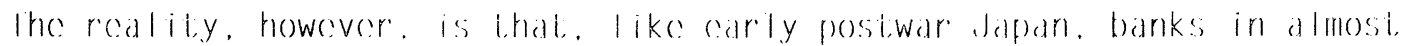

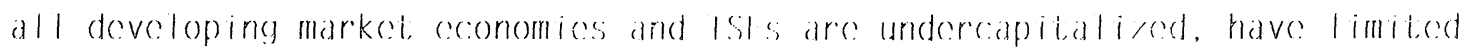

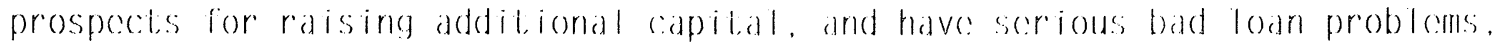

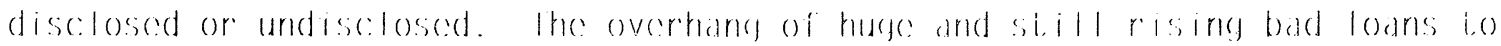

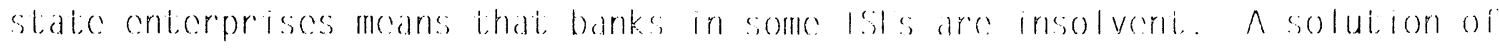

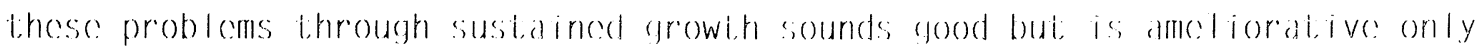
More! likely lhey will be resolved, as was done in carly positwar dapan, ihrough a

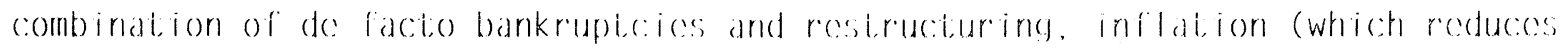
the roal value of loans and deposils); scequestereing of cxisi.ing ("old") bank depositis and loans in order to sitart frosh with "new" deposit and loan accounts: clcaning up the bad debt overhang over lime by writing off cequity and "old"

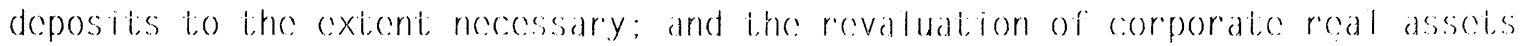
once inflation conds (or as il proceceds).

The hand of history has becen heavy on dopancese financial polic:ymakers, as

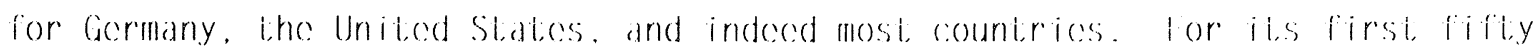

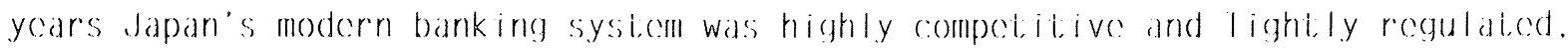
with casy contry and scanti supervision. llowevere recourring bank failures and

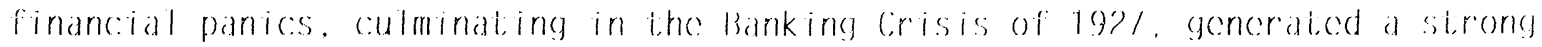

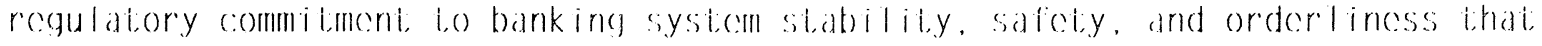

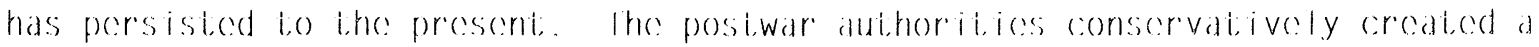
systerm and pursued policices which in pracieice not only iully probecied all deposits and depositors but provented any bank from failines. Ioposit, insurances was not a factors indeced a government compulsory deposit system was not ostiablished unitil $19 / 1$.

While serving as the lender of last resort, ihe monetary authoritios did not; want to create moral havard disincentives or condone mismanagementi. Iho policy approach was lwo fold: io conact prudential rogulation and carcifully 


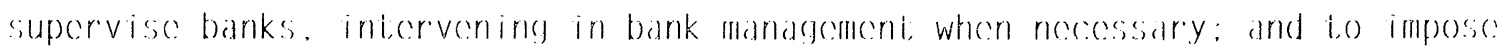

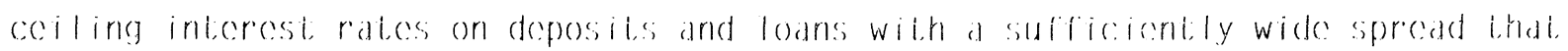
coven the mosti marginal bank, reasonably mandeged, would be profibable, since investment dermand and hence demand for loanable funds was high (sece the chapter by

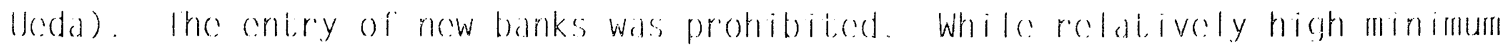

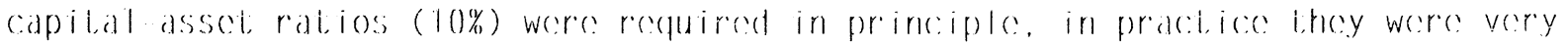

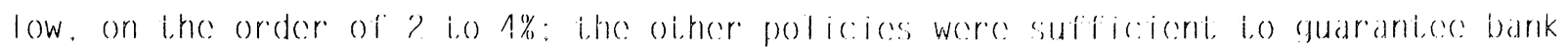
safely. Capital assed ratios became an issue only as bankine was deregulated and

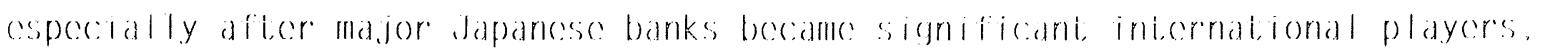

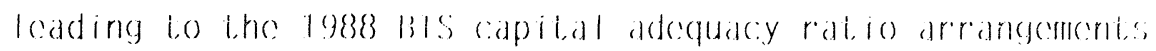

the banking systern was indeced very stable and safe throughout here high growlih era. No bank failed: a few merged. Realiecd loan losseses were very low in part because loans were generally well colladecraliecd but also because rapid

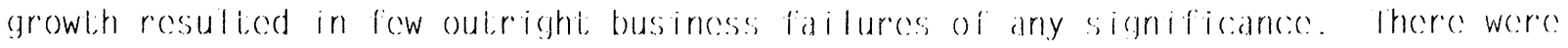
modest conomic losses borne by banks as they rescued and restructured firms in distress, lypically by reducing interesti rates on loans and extending repayment:

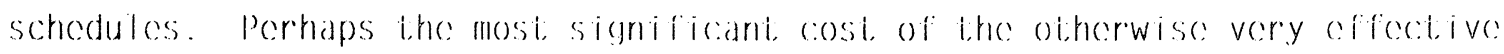
policices promoting stability was that bank management, cespeceially in small banks.

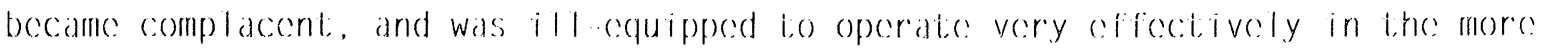
competitive financial cnvironment dercogulation has brought.

3.1 Low Intecrest Ratecs and I inancial Represssion

$\wedge$ key issue in financial development, policy is whether interest rates should be determined by supply and demand in the marketiplace or be set; at low coiling rates through gevernment policy. Low interest rate policies reduce the cost of funds to investors and the return to savers, ihercby providing incentives to investmont and disincontives t,o saving. Under a policy mandated low interesest rate regime, demand exceceds the supply of funds and crodit rationing becomes

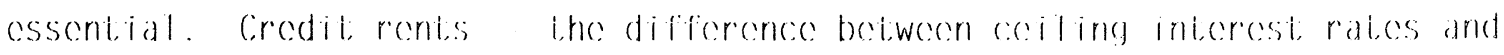
market interest rates are created and somehow allocated among direcet and indirect participants. The crodit allocation process accordingly becomes distorted by political factors, personalistic: considerations, rent secking bchavior, and corruption. To matidain the system contry has to be limiled. competition among financial institiutions and financial instiruments constrainced, 


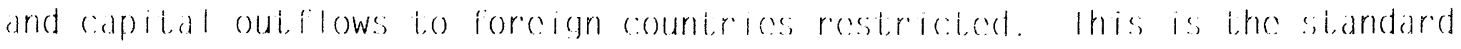
descreription of financial repression.

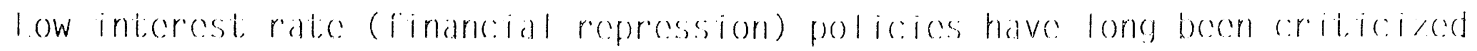

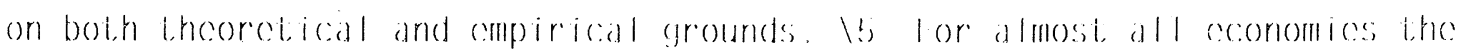

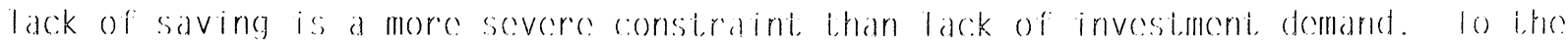

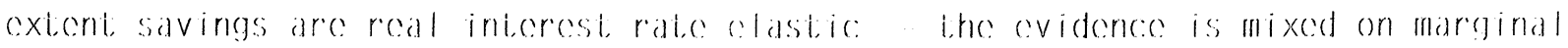
changes, bui, possibive where large changes ocecur due io subsiantial reductions in inflation then low interesest rate policices are counterer productive. On the investiment side, low interessi, rates create coredit rents and distort ceredit. allocation away from the most producitive invesimeni, prosecels. corruption in the distribution of credit rents occures at. i.wo levels: that of individual banks or

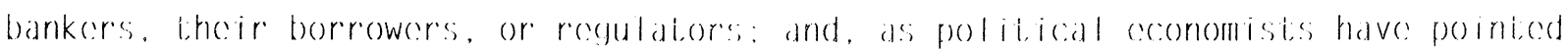
out. Lhe instibutionalied corruption of the politicial systern wherebto ceredit rents become a significant source of finances for the political leadership.

the degrec of financial repression is very important both as a policy matter and theoretically. Ihere is no substantial theoretical casce or cmptrical cvidence that negative real interest rates comance conomic and financial development. I ven with positive real rates the distortions can be large as an

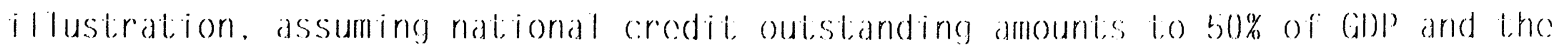
gap betwecen coiling and market interessi, rates is 10 percentage points, then the

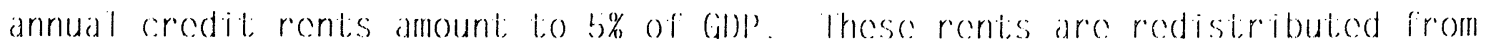

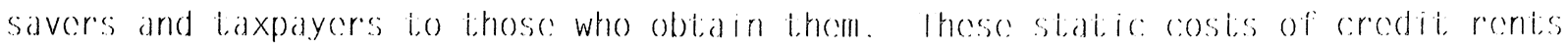
rationing are surely smaller than the dynamic consecpucneses of incefficiont resources allociation.

1 recont theme in the "new institiutional ceconomics" andytical approach is that a small degrece of financial repression may, on net balance, be bencficial or cven required in order to build financial insititutions necded for comomic: growith. the andysis begins wilh the proposition, cocriainly well recognied by all practical policymakers, that instibutions maticer. In the real world of imperfect,

b the classic: treatments are Shaw (19/3) and McKinnon (19/3); more recent andysis is provided by liry (19883) and Mo.Kinnon (19911). Ihe World Bank World Ixevelopment; Report: (1989), especially chaptecrs 3 and 1 , is replevie with discussion, examples, and datia on financial repression and the costs thercof. for a comparadive covaluation of financial repression in Japan. Korcea, and laiwan sec Patrick in Patrick and Park (1991). 
markets and imperfect and asymmetrically distributed information it is somedimes

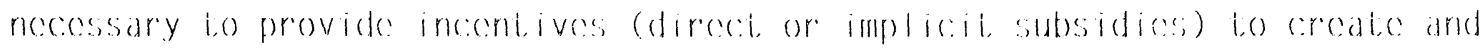

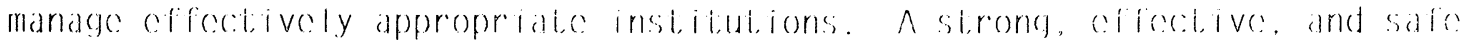

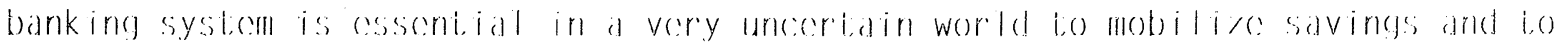

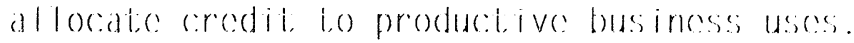

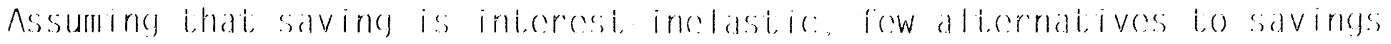
depositis are available, and depositiors have a high preferencese for safocity over

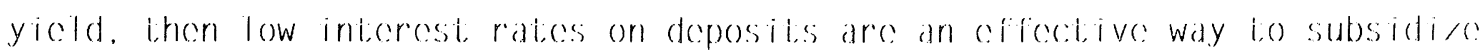
banks. Coiling loan interest rates are designed in principle so bhat banks redain part of this subsidy through a wide spread and pass on parti of it lo borrewers. Such a banking system should be autonomous, objeceitive, and rational in its loan

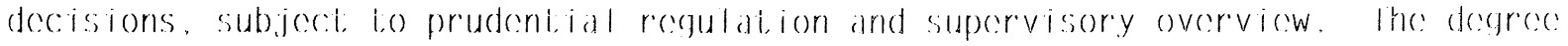

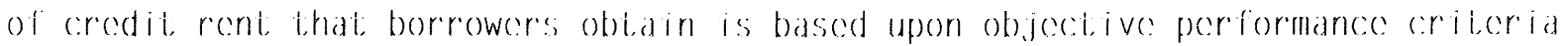
(output growith, cost reductions, cexporiss) as determined by industrial policy. In this vicw business crodit reni, sccking induces growith scek ing ouldomes (performance indexed rent. secking behavior). In this vicw, ihe degrece of financial repression should cequate at the margin it.s institiution building and allocative bencefits and its saving disincentive and rent sceking costs, and should be decreased as institutions become: stronger.

The carly postwar development of the Japancese banking system is put forth as an outstanding example of the sucecess of a modesti degrece of financial

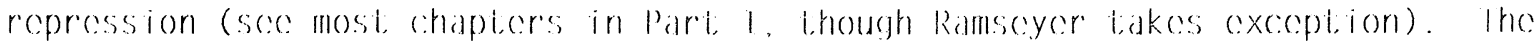
argument is that the carly positwar banks were fragile and recquired the implicit: subsidies of low interest, rates and wide spreads to build up internal rescrves and become strong over time, and the cntire system had becn made safo by restrictions on contry and other means of impliceit subsidy. Credit rentis were used for institution building and to provide incentives t.o appropriatec corporate: performance: and in this screse were desirable.

Bank interest rate coilings were operative mainly on bhe deposit side.

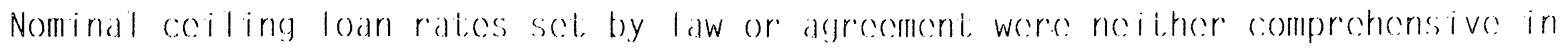
coverage nor. more importiant, binding whers they did apply. lianks recquired

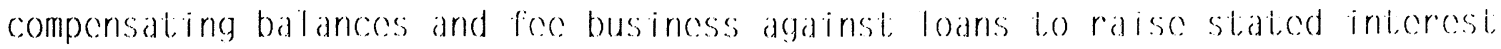




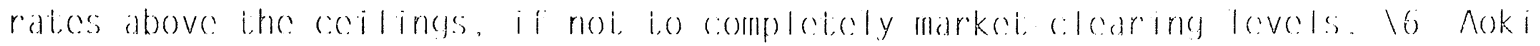

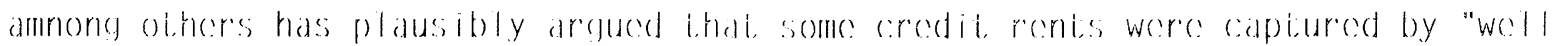

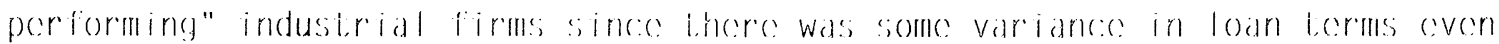

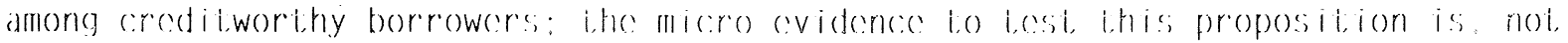
surprisingly, vory limilicd.

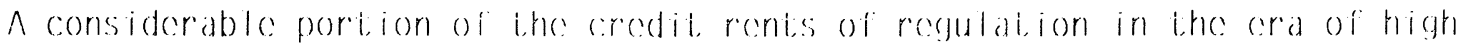

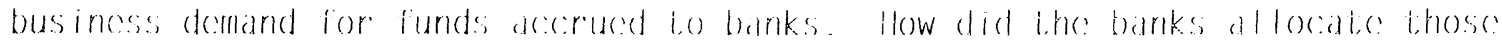

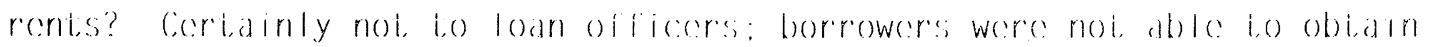

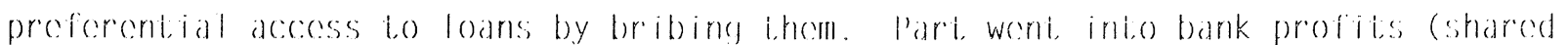

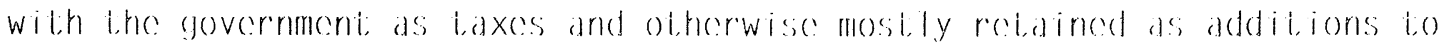

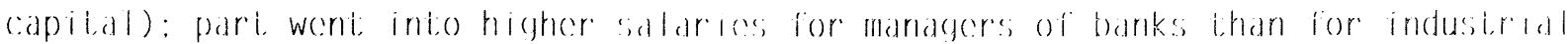

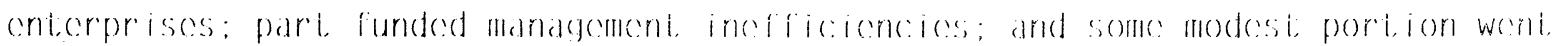

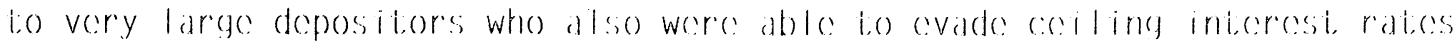
(1)alirick, 1966).

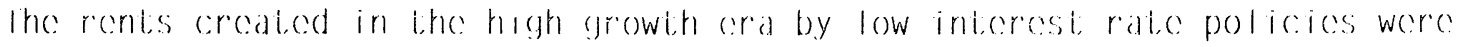

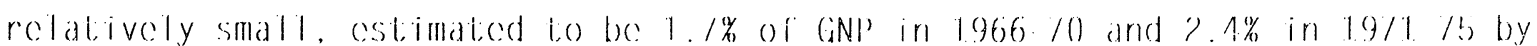
Teranishi (1993, p. 29) and somewhat, loss by Uceda (chapter 3). While ihe main bencficiarios were large firms, and the banks ihcmsolvos, iho costis of financial

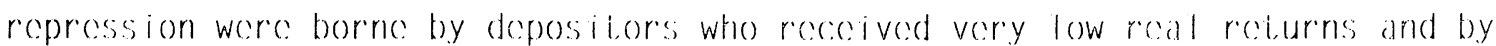

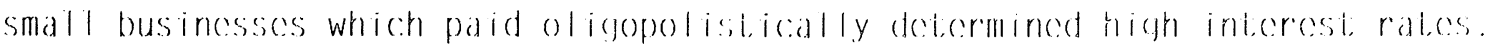

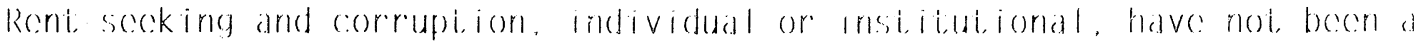

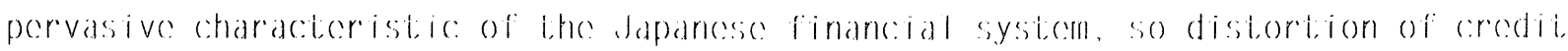

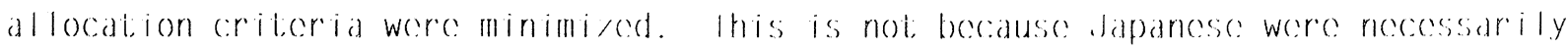
morally superior, although the perecoption that dafancese banks, bankeres, and regulatory burcaducrats in general are honcsi and rosponsible secmes valid. Rather. crodit rents from financial repression were not, very large, whilo the sancitions

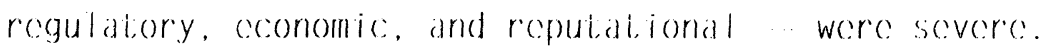

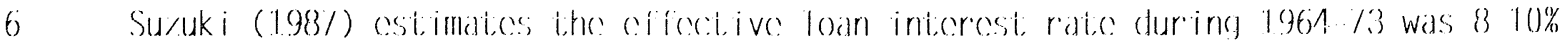

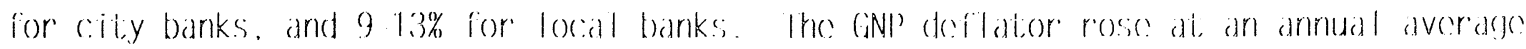
rate of about 2\% prior to the 19/3 inflation; while the consurner preice index rose more:

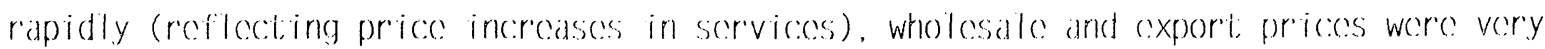

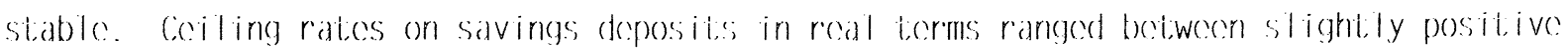
and slighlily negalij ve. 


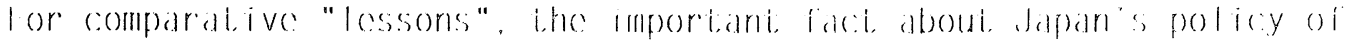

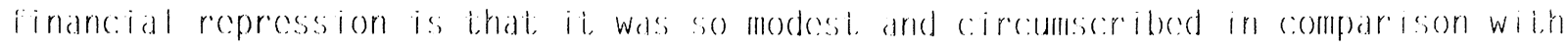

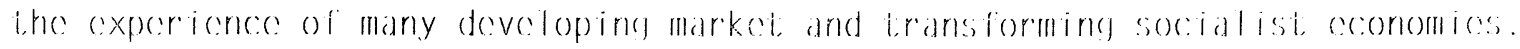

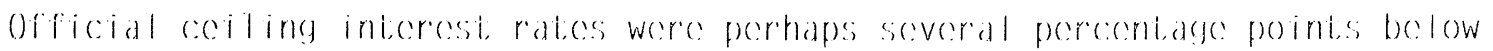

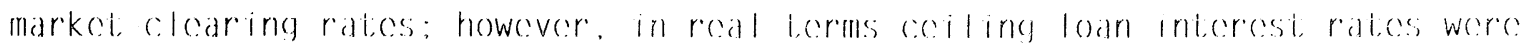

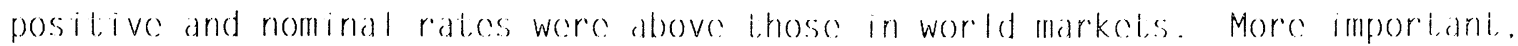

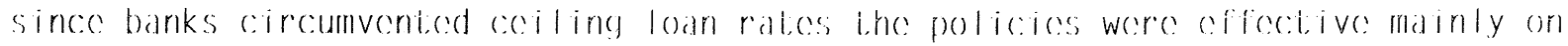

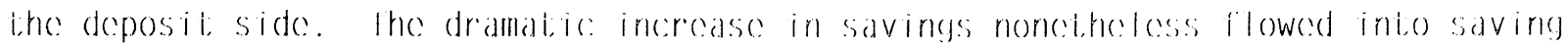

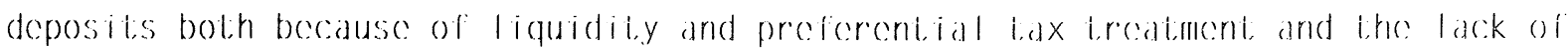

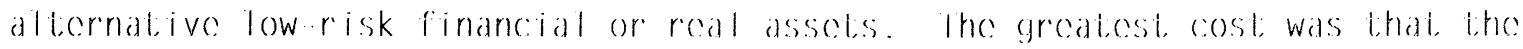

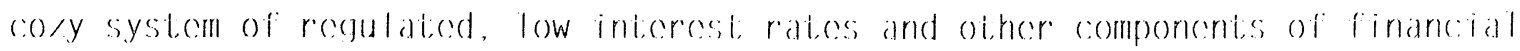

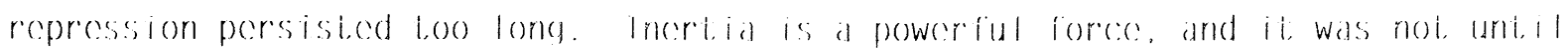

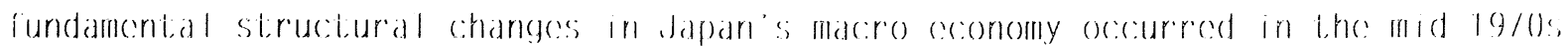

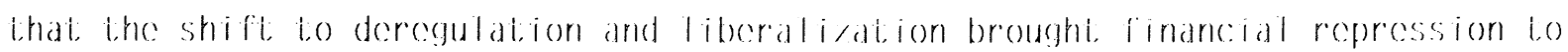
an crid.

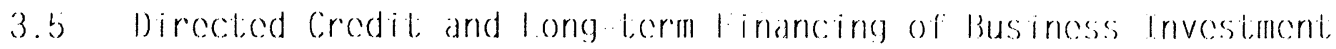

Rolated to financial repression but andyideally and cmpirically scparablo:

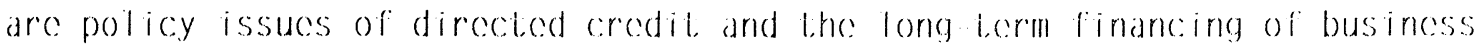
investment. Should government, polic:y make possible the provision of credit, lo

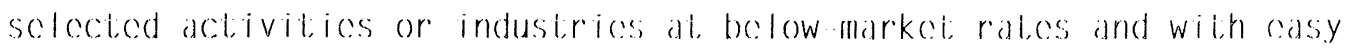
availability? If so, how should this be achiceved ifrough governernent or provale financial institutions? Who should bear the rostis of such crodit subsidics? What activitios should recoive the bencili? Cortainly a system of markel bascod

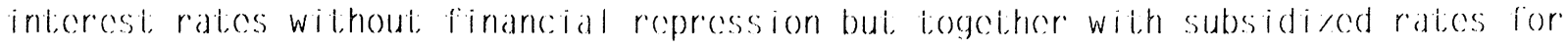

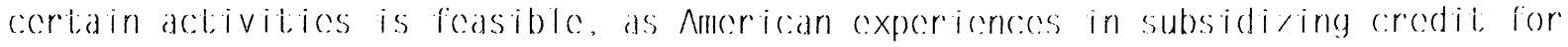
housing, student loans, and the like demonstidie.

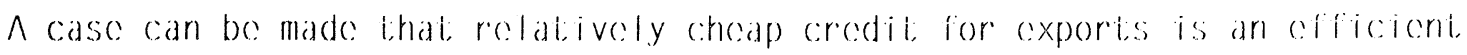

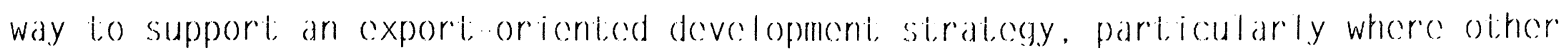
policios or market, distorlions make for disincentives to cexporting. Similarly. a case can be made for rolatively cheap corcdil for infrastruciure investiment. public ulititices, iransportation, communications wh where cxicrnal ceonomics are significant. Ihe most controversial component of directed coredit policios is loward solected "stralegie" winner industries (or smoothing the adjustiment of" 


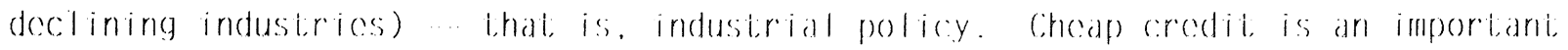

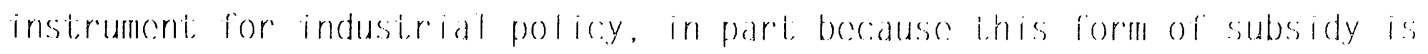

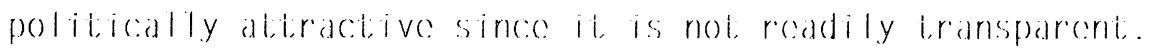

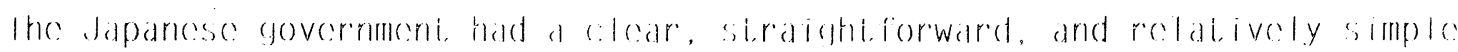

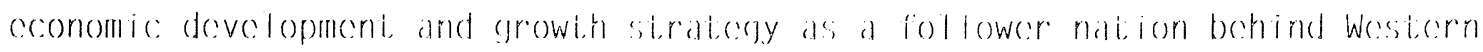

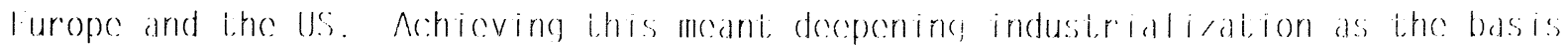

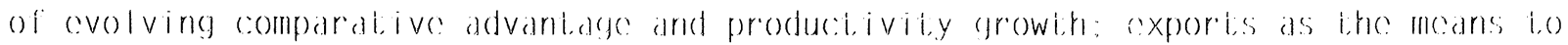

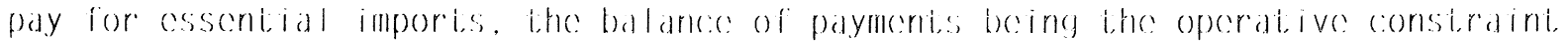

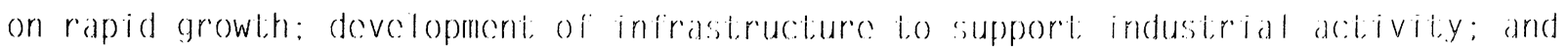

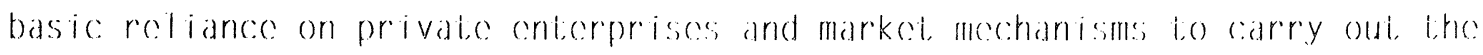
stralecgy. Japan was to col imb the development ladeder by moveng into cever more:

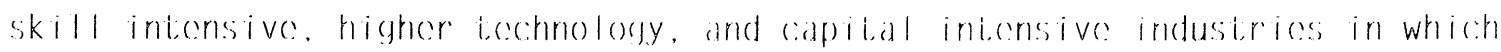

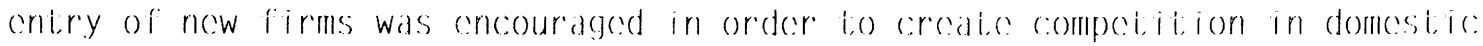

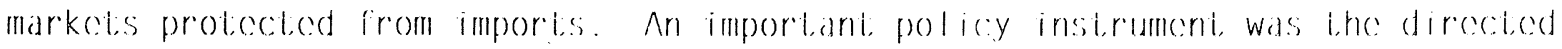
usc of crodili.

Policios to provide proforential financing for exportis had soveral dimensions. The bank of Japan rediscounded short iorm cexport, lirade bills ai, a low rate based on the New York marked. Ite citiy banks played i.te major role by lending lo their exporting industrial clicnts and especially lo lho general

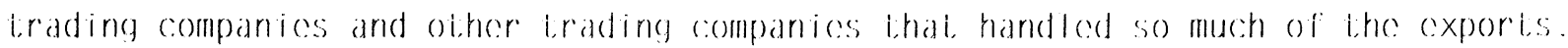

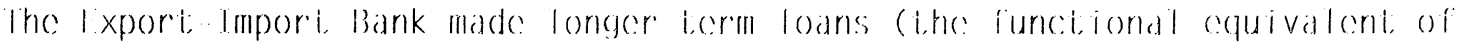

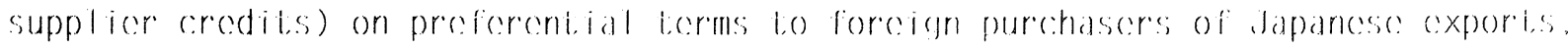
copecially of ships as woll as machincry and olher capilal goods. Iho dapan

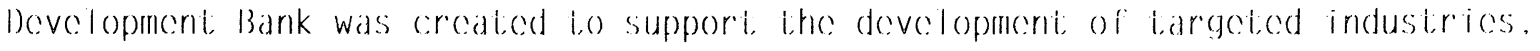
and some of lihem were involved in exporti producitorn. Overall, the subsidy involved in export cordits was not large, and exportis had lo mect the: compotitivenoss losts of intornational markets. Iho disciplinary role of the

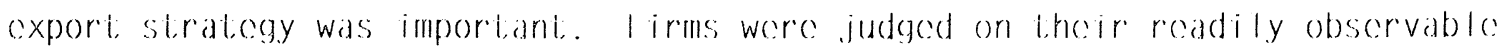
ceport, performance, so monitoring of performances was casy.

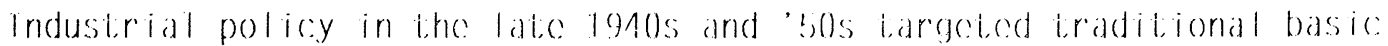

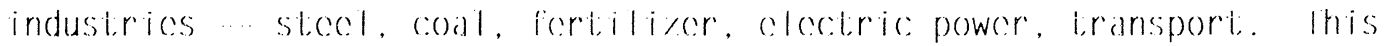

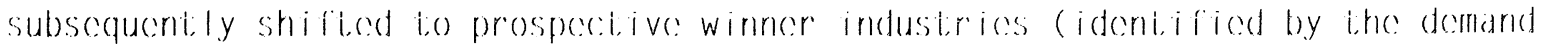
and industry structures of the United States and Wostern luropos such as petrochemicals, aluminum, shipbuildincl, commercial aircrafl, and later on computers and semiconduciors. Ihe basic approach was to rely on large privale 


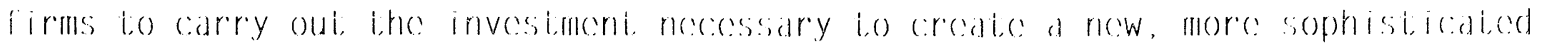

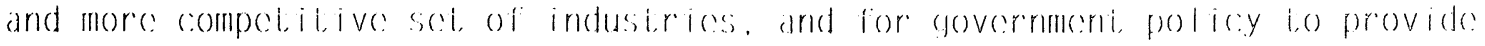

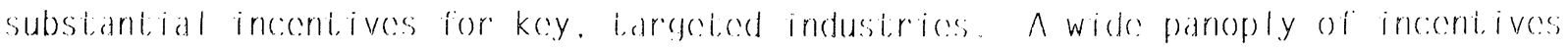

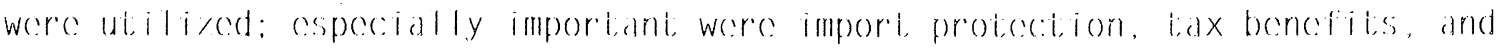

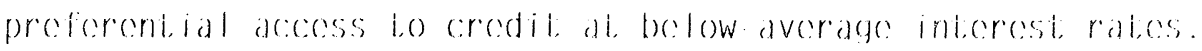

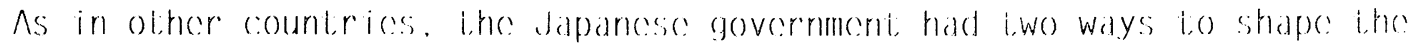
allocation of corcedit: it, could lend fundes under its direcei, conterol, and it, could

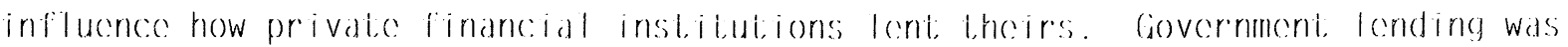
limiled bui of some significances: government, influches over privale lending was indirecet, relying on the finansial and incentive sitrucitures corcalod rabther ithan

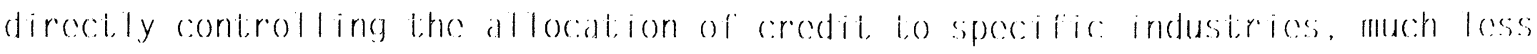

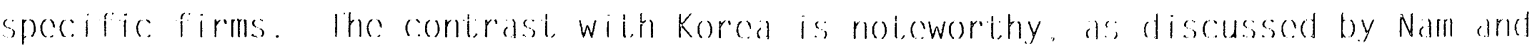

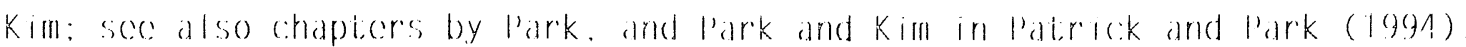

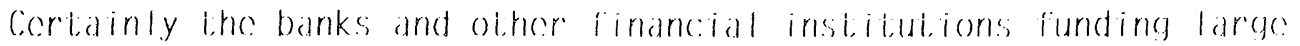
conterprisos were well aware of lihe government, s industry forioritios, and lending by the Japan bevelopment liank (JI)|3) and leporti Imporl Bank provided signals regarding government, policy. Ilowever, Ministry of linance direcitives lo banks as to what industries to lend to conded in the mide 19toss. Ihe industrial paticerns of bank Ionding were cortidinly broadly congrucni, with government induslirial prioritices, but this was because such loans were vicwed as profiliable and safo. li, is noleworthy that bank lending was much lower lo those fow scectors decrmed high priority by the government but judged by the banks as being less sale and

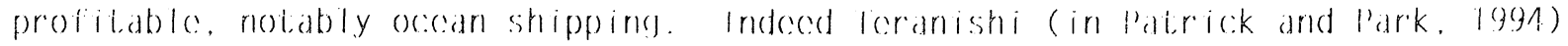
and others (sec Jub, 1993) stross that in even the high growith cra in practice a significant proportion of government, funding wernit to facilitate and smootih the structural adjustimeni process of indusidrics in trouble or decline, lo which banks were much less willing lo lend. such as coal mining once oil became a cheaper concroy source.

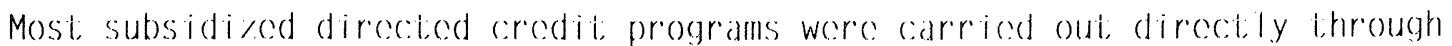
governmenit financial instibuijons. Iheoretically, the government, could have gencrated its loandble funds in a number of ways. In pracicice, il, reliod predominantly and incereasingly on the allocialion of postial savings depositss Lhrough Lho Ministry of linance Irust lund Burcau lo goverrment, financial institutions. financing by loans direceily from lihe coniral bank or indircecily lhrough fiscal deficits were adamanily rejecied since that had becn the major 
cause of the posiwar inflation. I inancine by running a gevernment, budget surplus, theoredically possible. Was not feasible politically (in that respecet the laiwan

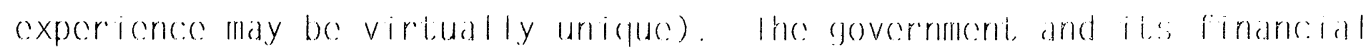
institutions (most, notably i.he dapan bevelopment. liank) did borrow from abroad and

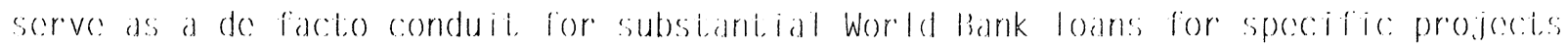

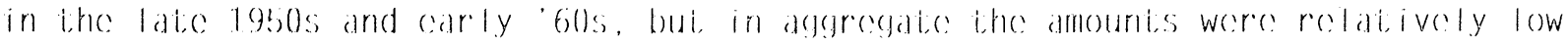
compared to total business fixed invesitment.

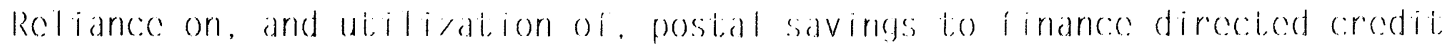
programs was important. It created the general perception that i.he postal savings were being used producitively, and that Icnding by government financial

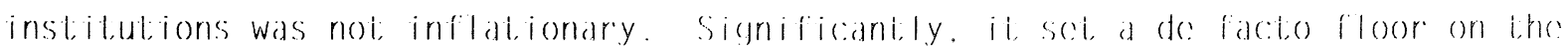

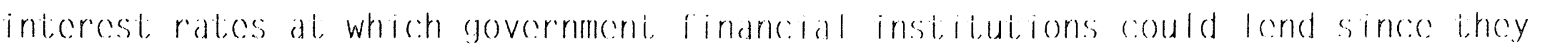
were required to cover the intereseit cosit of posial savings deposit.s, any loan losses, and be profitiable.

perhaps most importantly, ihe specific: loan decisions of goverrment financial institidions were not subject to political or government burcaucrat interference; they were rather well insulated from the sortis of direct personalistic, corrupt, or politically motivated prossures that have plagued Iending practices in so many other countries. once broad policy parameteres weres estat)lished (ceport credits and the financine of lixed investiment for infrastructure and the priority industrial seciors). credit, was allocated by loan officors applying objective coreditworthiness criberia. They cevaluated the quality and riskincess of projecis, they required speceific: collaticral, and they were i,ought on potcential defauling borrowers. Aciual lending praci,ices were conservative. and were exteraordinarily successful: there were virlually no cases of outright. borrower fatlure, loan losses were very low, and the government; institiutions did not lose moncy.

Japancse policymakers recognied the contral rolo of business fixed investment, and cestablished an insititutional structure and a set; of policices i.o provide preferential access lo long term financing ab relatively low cost for large firms, especially those in targeted sectiors. Ihe general theorotical rationales were market failure and term mismatech. On the one hand, uncertadinty of success of investiment projectis and inadequate information to cevaluate projecet feasibility and firm coreditworthiness made the fong term commitment of funds appear ceven more risky than in fact, was the case. On the other hand, savers 


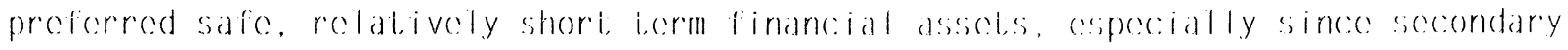
markedis were undeveloped and inildidonary feares peresistied.

Iong term funding was supplied primarily by icerm loans made: by governoment.

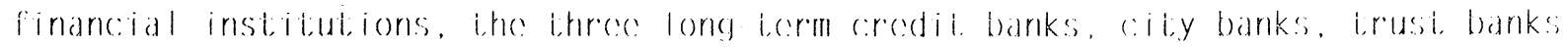
and life insurance companies (sce the Paseker chapter and alli, 1993). Ihis was i.ypically in the form of de facio syndication of projece loans involving all these

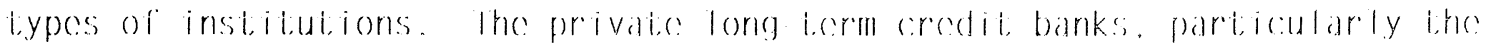

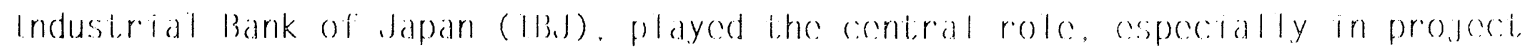
cvaluation. Over time the main bank developecd a egredecer capability and took a

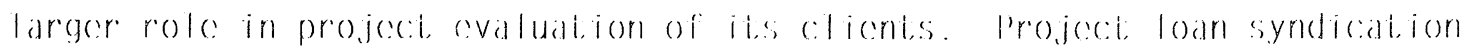

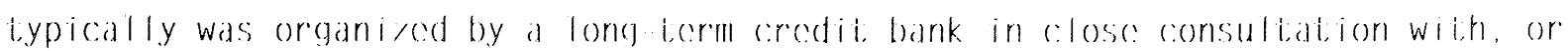
conorganization by, l.he borrowing firmes main bank. A c:loses, symbiotic:

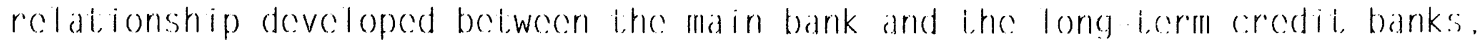
though the latter were careful i,o work with the full range of main banks, and not, lo identify particularly with any single Big six koirctsu.

A significant source of long term funding in practices, not recorded in the data, was the rolling over of short term credits by the commercial banks, in particular by the main banks to their clicnts as an integral component; of their long i,crm relationship. A main bank commitmenti, i.o its relationship impliced a promise to roll over short, ierm ceredits, and this was an important signal to the other Ienders to itis clicent.

By law and pracioce the dapan bevelopment lank played a significani, but more narrow role. complementary to private financial instibutions. As of 1961 . 90\% of its outstanding loans for plant and equipment; invesitment were to four industiries a.. clectric: power. occan shipping, coal mining, and iron and stecel while those of the long term credit and other private sector banks were distributed over a far wider range of industries. Ihe dols's main broader role was as an information producer for borrowing firms, thereby reducing agency costs. Through its close rolationship with the Ministry of International lrade and Indusiry (MTIT) it, could make firms aware of invesi.ment opportunitices and government; policies towards industiry. cespocially ihose without stable long icerm main bank rolationships (lloriuchi and sui, forthcoming).

The J)B has becn a succossful exception to the sad history in most developing markci, coconomices of governmeni. owned development banks, prociscly because it was constrained to be conscrvalive in loan decisions, require: 


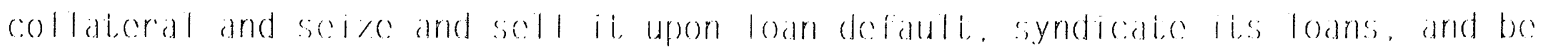

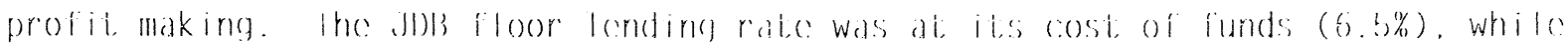

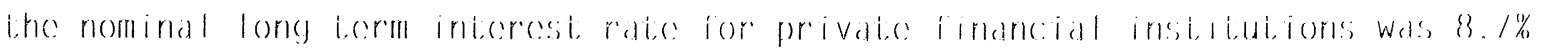

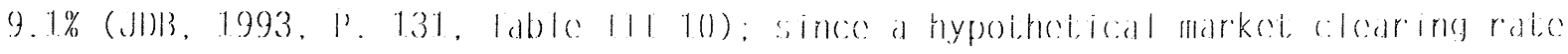
was somewhat higher, the Jlob loan subsidy was on the order of 3 i,o 6 perecentage points, substantial but far less than in many developong markcit coonomices or ists. Credit, rationing was more significant in long lecrom finance than in thes

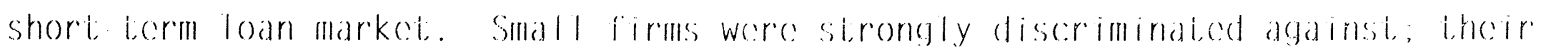

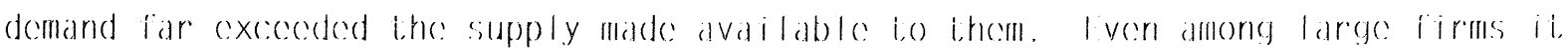
matiered to some degres: whether they were in priority industries or not. necoss

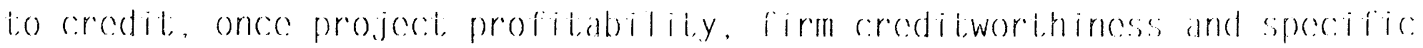
collateral requirementis were med, was probably more imporiani, in promoting

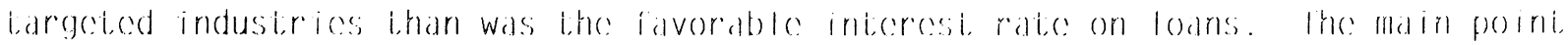
is that there were many potentially profitatile projecets so londers could bechave

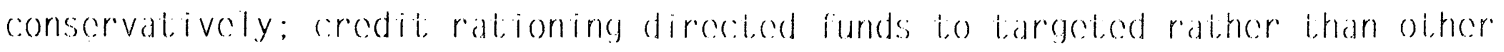
uses. The rolatively low long term interest rates bencifited companies both in cost; terms and in providing a favorable numeraire for projeci, covaluation.

the effective interest rate on long term loans was positive, higher than for short lerm loans, and yet lower than (implicit, market Iong icerm rates. Ihe: average cefective rate was reduced by the blending of rates on different, components of the syndicated loan: lowest from governmenti financial instibutions, higher on lihe private Iong icerm credii, bank portion, and (probably) highesi, on the main bank, other city bank, and trusti bank poritons. The private financial institutions offset, at lcast partially, their low nominal long tecror rate by requiring compensating balancess and high foces for other financial servicos. I ong term credit banks required borrowing firms i,o purchase their financial debentures (their main source of funds) as a compensatory of reset.

policy support for relatively low long tecrm intecresti radices came from liwo sources: the flow through of cheap postal savings depositis, and the provision of cheap ceredit by the Bank of Japan. The Bank of Japan provided for stable growith of the moncy supply primarily by lending to the citiy banks (and only the citiy banks), which chronically borrowed a substantial portion of their totial funds from it. This policy was not inflationary because the government, mathianed a balanced budget, the increase over time in foreign exchange reserves was modest, and open market operations did not; cexist. Contral bank loans and discounis were at. low 


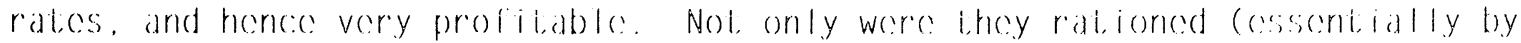
bank sios so long as lihe banks followed lihe guidances of lihe authoritios),

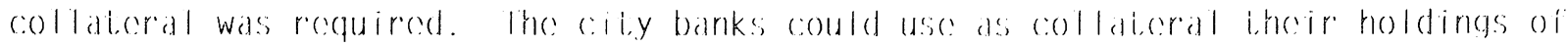

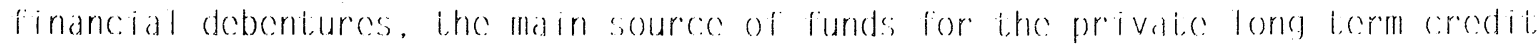

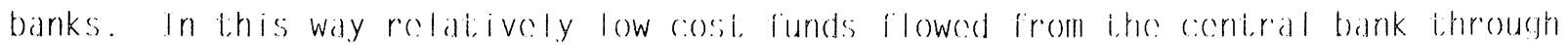

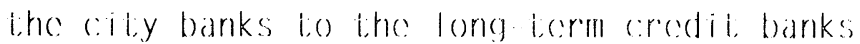

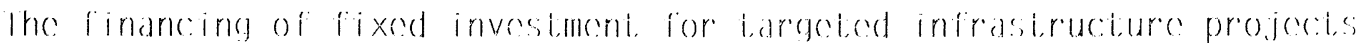

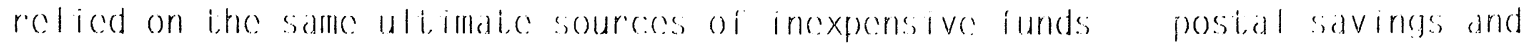

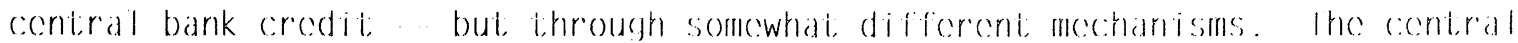
governmenti dircotily owned the nalional railroad system and tho tolocommunications

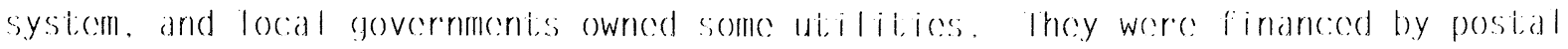

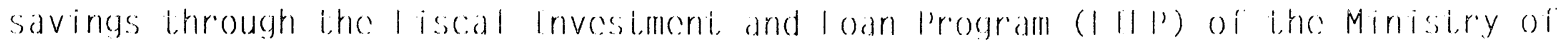

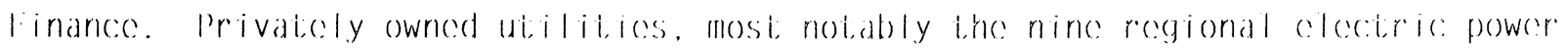
companios that scrvice mosi, of Japan, issuced substantial armounts of bonds as woll

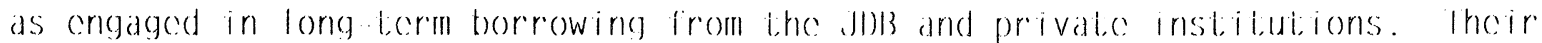
bonds were also issued at relatively low interesti rabes and sorved as collateral for bank of Japan loans to the ciliy banks. Bond issue by industirial sorpordi, ions was soveroly restricted; they wore purchased disproportionatoly by the main bank. Secondary markeis were discouraced for all bonds: government, financial. ulililices, or corpordic: $1 \%$

The issues addrossed above on financial system architeceture and government: financial policy impinge dirccily on the policices and bechavior of banks. Ithrece issues de lhis more micro level are considered here: corporate governance; coredit.

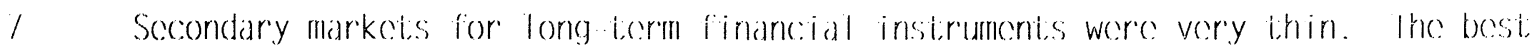

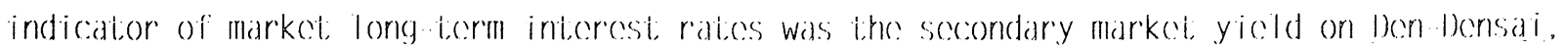
the small denomination bonds issued by i.he governmenti owned Nippon lolephone and lolegraph

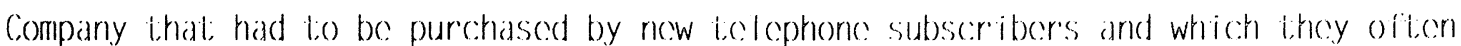
immediatoly sold over the counter. Those yicleds were lypically substantially above nominal coiling long lerm rates and several percentiage points above ceffective short lecrm bank loan ralies. 


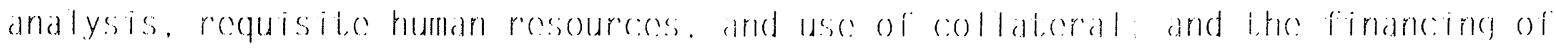
small business.

1.1 The Governances of banks

Who owns the banks, who controls them in normal circcumstancess, and in times of bank distress? Covernances involves control over mandegement and

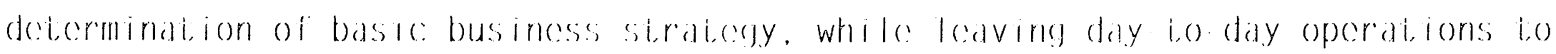

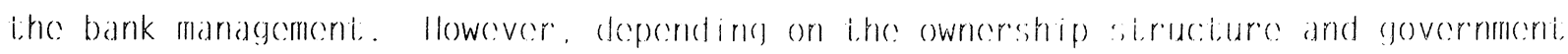
policy, ihose who own or conitrol may be mush more inirusive, going so far as to shape specific loan decisions. Covernance is particularly important in situations

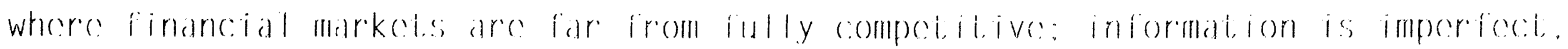

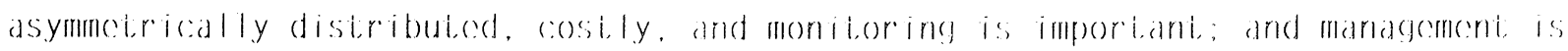
a relatively autonomous agent. Inder these circumstances t.ypical in almost. all developing market conomics and lsts banks incvitably will have a cortain degrece of market power.

$\Lambda$ contral issue, especially relevant in the contexi of less developed conomies, and tsls, is the potential for misuse of power particularly intrusion of non objective criteria into specific loan decisions by owners, by the government, or by autonomous bank mandegers i,hemselves. Siate owned banks are

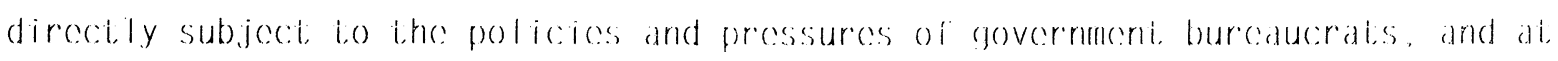

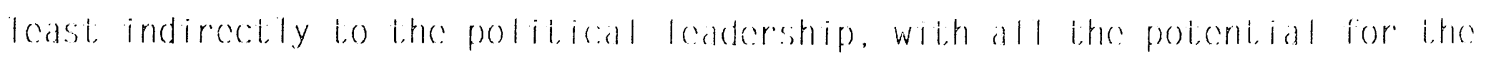
infusion of politisal, rent sceking, lurf maximising or other non objeceitive criteria (sec the chapters on chind. India, and poland). Ni, the other exi,reme is the situation where ownership is in the hands of an industirial family or business group. (The cahpter on Mexico describes the shift from private io state ownership) and back again to business group ownership.) Ihere the danger is that the busincss group will preforentially concentrate bank loans i.o it.s own conterpriscs. at the expense of potentially betier loans, or minority sharcholders, or depositor protection. Where stock ownereship is widely dispersed, as in the casce of targe Japancese financial institutions. then ownership and conterol are separated with great power vested in autonomous managenenti.

$\wedge$ basice objective of government prudential reguldion and supervision. and disclosure requirementis to conhance transparency, is lo prevent the misuse of power by owners or managers. Bui, ceven when substantial ownership is private, in some: 


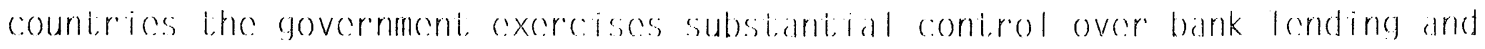

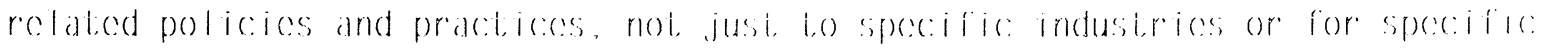

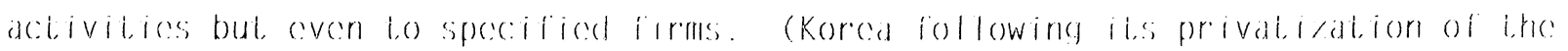

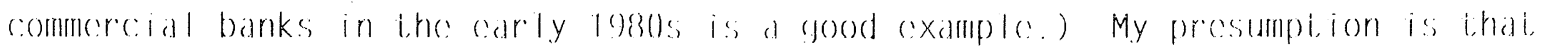

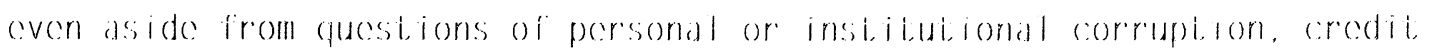

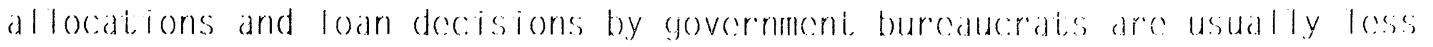

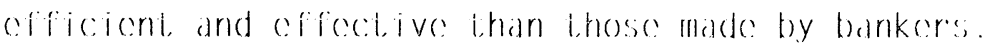

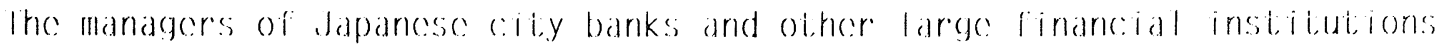
have had greal auionomy from sharcholders. Sitock is hold prodominanily by fricandy industrial corporations lo which lhe banks lond (and in turn hold sharess) but in a highly dispersed fashion in which l.ypically ros single company holds much more than 1\%. Ilostile lake overs bids have becen unheard of . Ihe pressident and

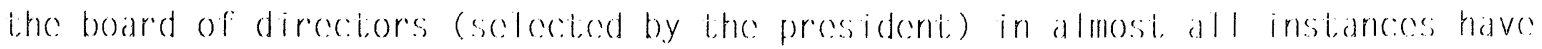
becn promoled from within. having riscen over gej years or longer ithrough mandgement. ranks. Ihe Ministry of linances and liank of dapan sol the rules, supervise, and provide administralive guidance, bui, ihey do not, imiervene in bank decision making or in persomel maliers. Ihe rules of the games of good bechavior were ratiher specific and precise, monitoring by ihe duthoritices weres presumathly rather intensive and informed, and the incentives for playing the game a greater growith of bank sios and profils by oblidining branch liconses and cheap contral bank crodit were wubstantial.

In normal limes governance was subtle and indirecit. Ihe corpordic cithos valued firm sioe; the slabus of a bank and ils management depended more on ils

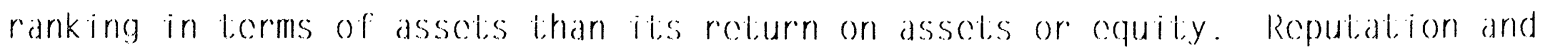
pecer group prossure weres importianti, reinforeced by the systen of delogated

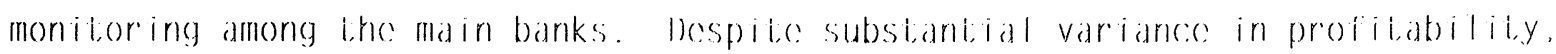
banks moved along in a "convoy" of rolatively stable growith and ranking.

What happens when a bank falls inio difficuli,y. cocon distiress? In lihe high growith cra that, was never really an issue, given the policy and siruciuro: il. occurred for only a few small banks, and then the Minisiry of l inance intervened reducing dividend ralos, changing mandgement, dispatiching a Ministry of linanco official to liake over. In the worst case, the coonomically failed small bank was casily merged into a larger bank sinces it had lihe valuable asset of deposit. collecting branch offices. Nil this was done quiclily, discrectily, with litilie disclosure. Wilh separation of ownership and managerial contirol, stockholders 


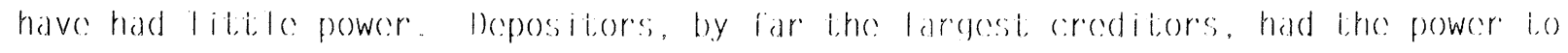
cxit at lithe cosi but they virtually never did because they belioved the: safely of their depositis, and indeced of the bank. Was suaranicesd by the: governincrit.

li, may woll be that serious governance problems for dapan's banks will cencerge in the 1990s. Ihe overhang of bad lodns sesmes to have put several larege

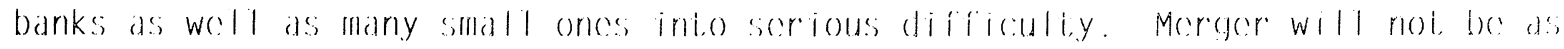
casy a solution as carlier sinces derecegulation has sharply coroded the franchise

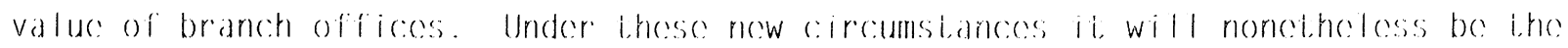
Ministry of linance, assisted by the bank of Japan, that will exercise control, providing coredit and fiscal incentives, behind the scenes. Hostile meregers ithrough i.he siock market ares very unlikely.

\subsection{Credit Mnalysis and lluman Resoures Requirements}

Providing rinance requires that creditors have the capability to covaluate potential projectis and corporatice colicnts, and to carry out the provision and management; of financial services. Ihe single mosi, important bank Iending problem is how lo assoss the creditworthincess of borrowers. Risk assossment is not casy under the best of circumstances since information is imperfect, asymmetric, and costily to obtiain, and the future is uncertain; some possible states of nature create losses beyond the control of the conterprise or bank. Ihe cessence of coredit. analysis is monitoring, bui, monitoring under the main bank systern is more ihan that. Ti, includes cvaluation of new projects, evaluation and some influchece on the performance and behavior of the comterprise's ongoing activitices, and rescue or liquidation of a firm in acule distress.

Banking and finance skills are particularly important where the information infrastructure of accounting, additing, cconomic intelligence, and disclosure are underdeveloped. The shortage of human resourcess with such skitls is a serious problem, particularly in transforming socialist conomices which have litile history of such skill formation. One approach is initially lo concenterdo skilled staff at, a fow institutions banks, development banks, institutional investment, funds and over the longer run build up the human resource base through tiraining and on the job learning and spread it through a wider number of institutions. 


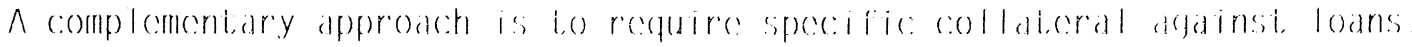

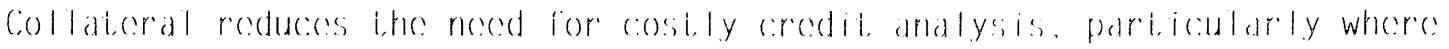

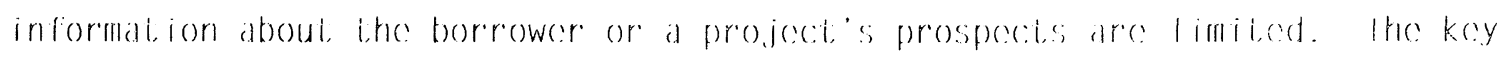

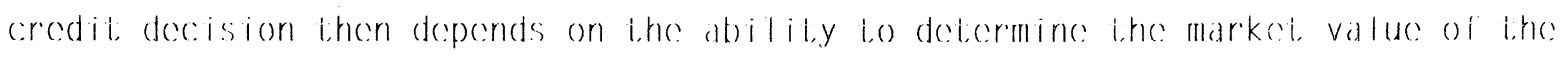
asset used as collateral, in cefrect substituting knowledge about ho collateral for knowledge about bine borrower. Ihe problem is that owneres of asseds are not. necossarily the best cntreprencurs. developers of projecis, and mandgers. Japan's prewar and warlime cexpericonce in operating and mandeging banks produced a fairly large number of commercial bank managers with substantial human skills. The the provided an imporiani reservoir of lalceni, skilled in prosecei,

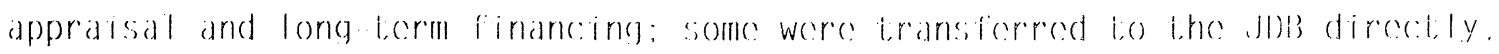

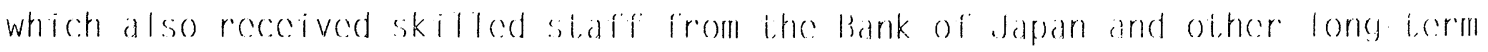
financial instibutions. N1l banks have spent considerable cofore recruitines outstanding university graduates and developring stafie capabilitices recinforced by the systems of permancent comployment, job rotation, and competiticon for promotion based also on scriority within a hicrarchical system (sece the Sunamura chaptere). In particular the main banks developed strong moniloring capabilitices regarding their major corporate clicents, cespecially for ongoing acitivitices and in situations of trouble and difficulty. However, ihe immobile permancent cmployment; systern, cspecially the policy not lo hire mid carcer mandgers from other institutions, scriously inhibiled the transfer of human skills from one bank to another.

Japancese financial institudions have a long history of requiring speceifie:

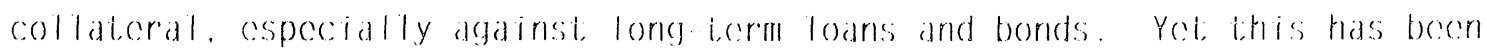
regarded as one componcent of a bank colicnit rectationship. not as a substitude for developing that relationship. Pant and equipment, has typically becen scquestered as collateral; since the scrap value was relatively low, project cevaluation required cash flow andysis as well. In the high growith cra there were conough cntreprencurs with good projects and with collatcral (including third party guaranteces) that credit allocation worked offectively. The main bank system has always combined the use of collateral with intecnsive monitoring to ascortain a firm's future prospects. secking to distinguish betwecn polential borrowers with excollent growth prospects but litile collaticral and those simply with sufficicnt asscis.

4.3 The linancing of Small liusincess Rolative lo large 


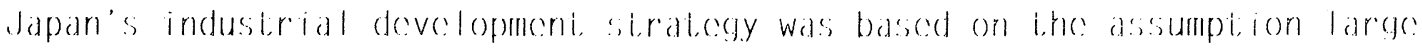

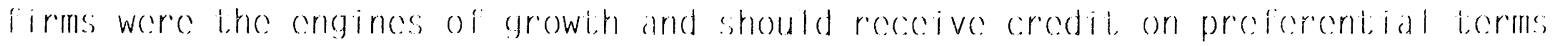

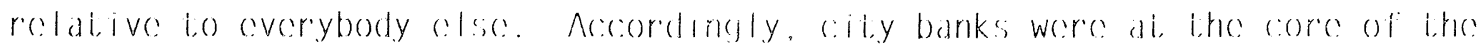

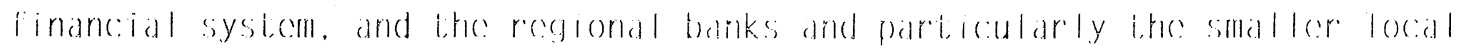

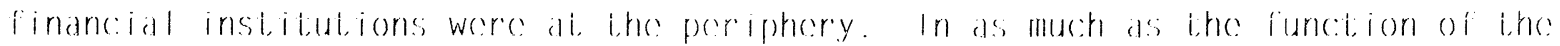

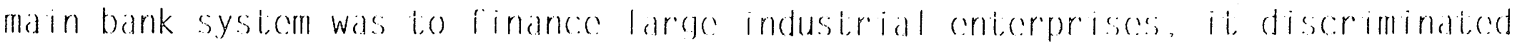
agdinst, smallor borrowers.

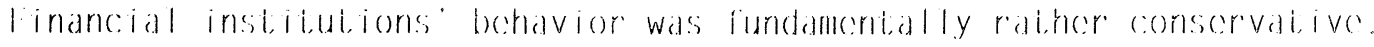
They could afford lo be because, with such rapted growith of oulpui, and so many

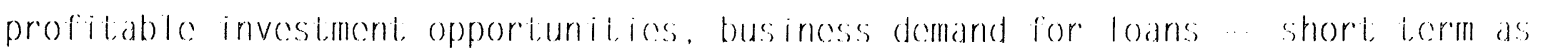

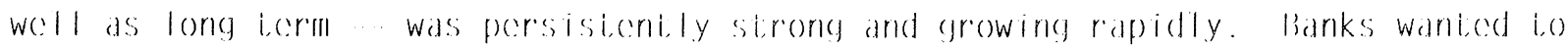

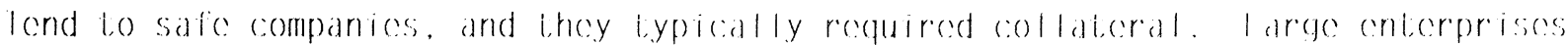
were generally regarded as safor berroweres litan sillall onces.

Small conterprises in fact produced most of lho industrial output and comployed mosti of the industirial lator forces. Most did have accoses lo short tecrm

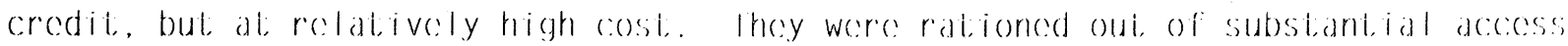

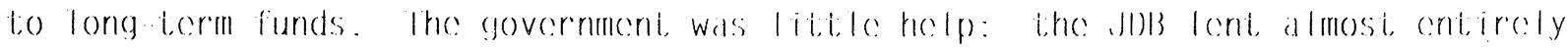
lo Iarge firms; and lhe Small Businessi limances corporation came lo play a significant role only from the 19/0s (Cialder, 19838). Simaller firms fadecd an

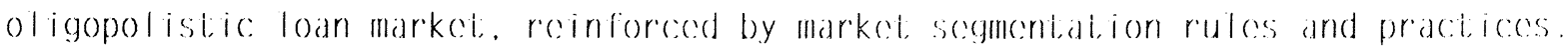

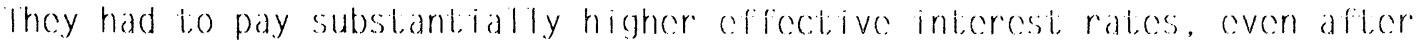
adjusting for transactions costs and risk: Lhoir compensaling balances weres much higher lhan those of large firms.

In fact dofauld risk was low because lenders required full collateral from small borrowers. When borrowers defaulied their eollateral was soired and sold so the aciual loan lossos by financial instibulions londing to small businoss were

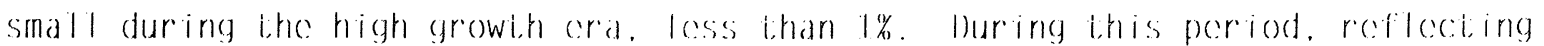

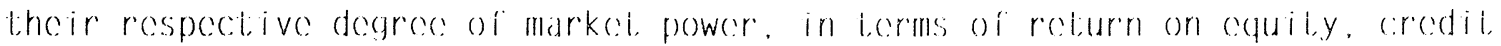
associations were the most profitable, ihen muidal savings banks (sogo ginko.

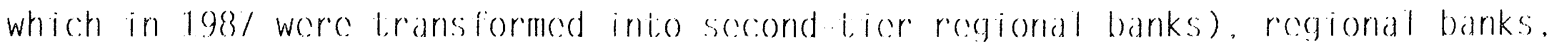

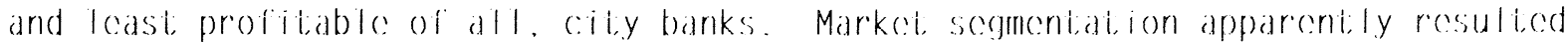
in loss than optimal allocation of loans by firm siec dospile an aci, ive inderbank call markcil.

the main bank system as definced throughoui, ihis book was csscritially only for large industrial firms, coven though small conterprisos iypically cla im some 
form of main bank relationship) with their premary lending instibution (sces i,her

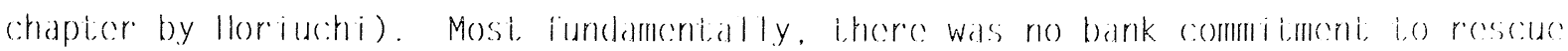
or restructures a small firm in desteress. Ihe nature of the bankines restationship

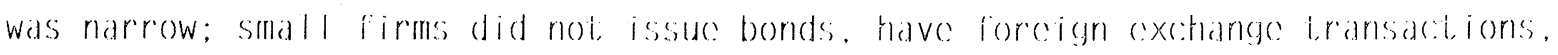
or generate olther foe business, and banks did not own any of their cquity. Musch of the problem in lending t,o small business was the lack of information. the cost.

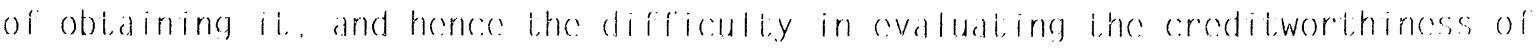
small business borrowers and their collaticral. Monitoreine of company performance accordingly was far loss thorough; he costis outweighed any bencilits.

Ihere were other importani sourcese of small business ceredit, notably the huge amounts of trade ceredit. Iarge manufaciuring firms and large trading

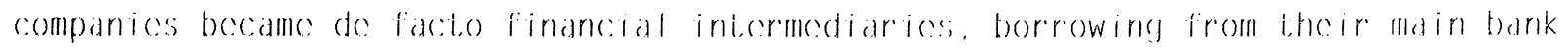
syndicale and providing coredit, lo related subsidiarices subcontraciours and wholesalers since in the normal course of tussiness they developed superior accoss to information about their cereditworthincess.

Venture capital institutions to provide risk capital for new, small contreprencurial slart ups did not, exist in the high growih crat and have becn slow to develop subsequently. New small firms had to finance themselves just l ike new firms ceverywhere: the owner's savings, borrowing agdinst, the owner's real asseds. and credit: guaranteces by relatives and friends. Yeit the coni,reprencurial drive i,o set up one's own firm, to be one's own boss, is strong in dapan; cevery ycar more new small firms were cestablished than in the Inited Statos, and cevery year more fatled or otherwise exited. And some erew t.o become larege and well known such as Sony, Ilonda, and Kyocerat.

I.essons from dapancese I inancial bevelopmenti

The main bank system was at the apex of the Japanese financial systerm in the high growth cra and arguably still is. In important respects it has epitomied Japan's financial structure and policiess. In the ceonomic and financial convironment of the high growith cra the main bank systen matured and flourished. It represented a successeful solution t.o a key developmential problem:

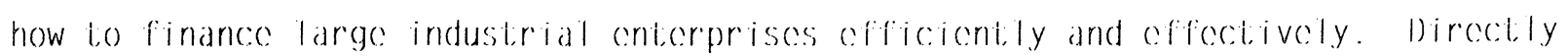
and indircetily, notably in cooperation with the long torm credit banks, ihe main 


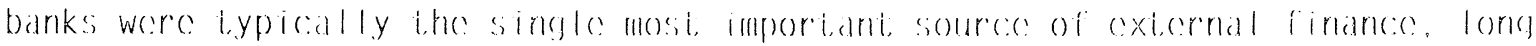

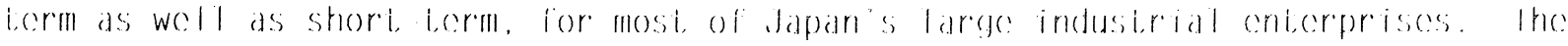

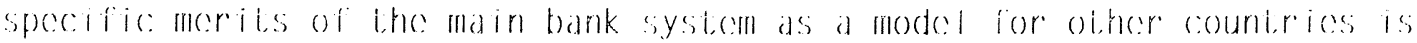
discussed in mores devail laber in ihis sceiton.

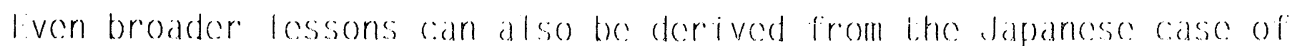

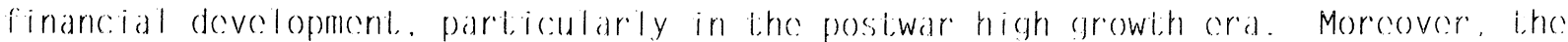
main bank system cannot bo revaluated in isolation; dfier all, it, is a subsot of ihe banking system, which has constitiuled ihe cores of the dapancesc financial system. The acknowledged effectivenoss of the dapanose financial system depernded

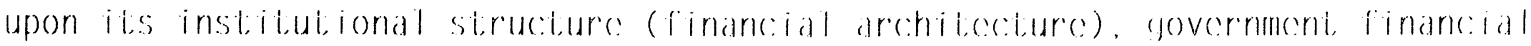
policy, and the macroceonomic polis:y convironment, as alroady discussed. Ihis does

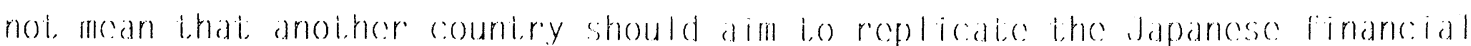

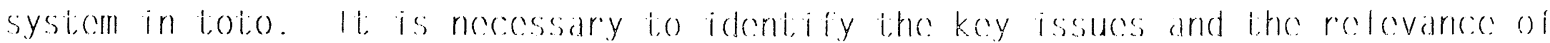

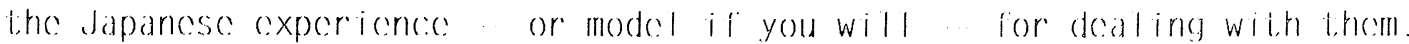

Ihe lossons for financial instibution devolopmenti and for appropriale policies aro cessenitially sitructural and longer run. Policymakers must have some long term (10 lo ?o yoar) vision of what the financial systicm should bes, and an

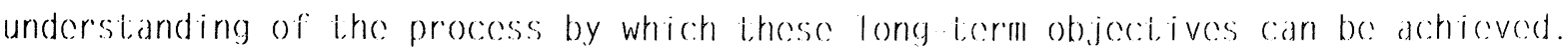

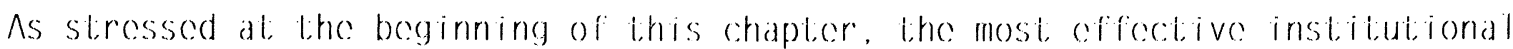
arrangements and policies depend critically on cach country's own goals, its own history, and ils corrent, siluation. It, is importiant to remember that oven in the

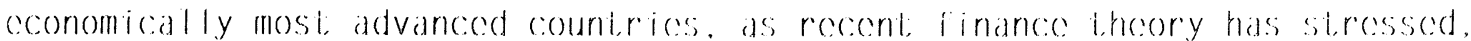
markciss are incomplete, information is imperfoct and costiy lo obtain, and it, is not possible lo write compleice contrades covering all contingencies; the conditions in developing markot coonomics and 1 sls are much furtifer removed from

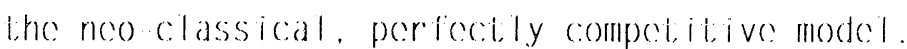

A skeptical view of lhe styliosd factis of the protolypical doveloping

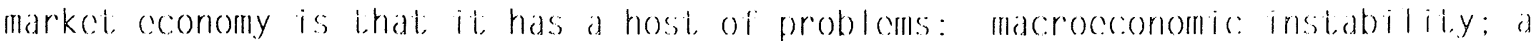
limiled institutional and physical infrastruciturs: low levels of comomic, business, and financial informalion; quile imperfect markeds with considerat)le market, power and profound information asymmetries; woak banks and capilial markois; and lack of human capilal skills in finance and oblecr areas. protolypically, ilis

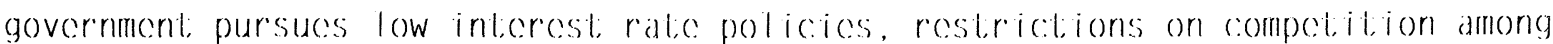
financial instibulions, and crodit rationing; financial reprossion is moderate lo scvere. Accountability .... sanclions and rewards ... for decisions is not high; 


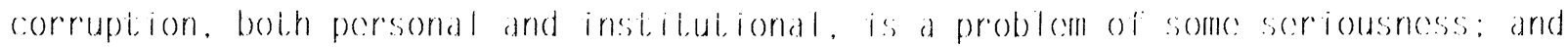

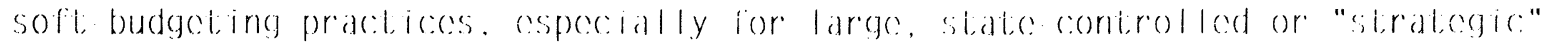

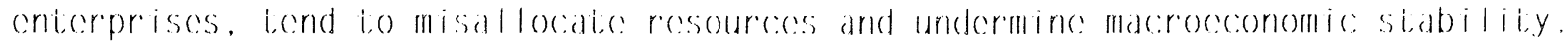

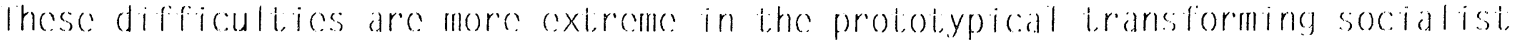

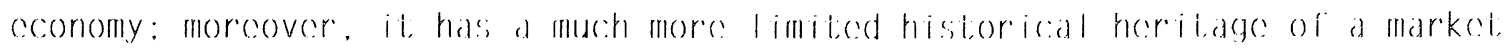
coonomy and ils institutions, and a profound lack of requisiles human skills. Ii.

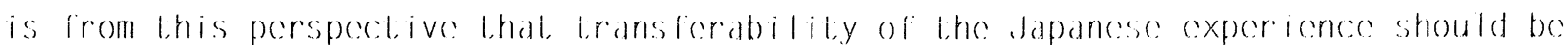
comsidered. 
9311903

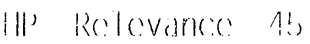

b. 1 Goncral l cossons

b. 1.1 Macrocconomic: Siabiliti.y

The most important general leseson, and not, jusi, from the dapanesse:

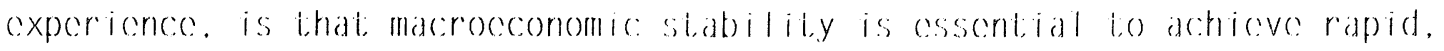
sustained ceconomic: and linancial development and. over bimes, a mores open and compotitive conomic: system with strong financial instibutions. Control over inflation is essential for the development and cffecetive funcitioning of the financial systern. Most savers mainly demand safo, liquid financial assots (depositss) whose real value is not croded by inflation: only as there wedih

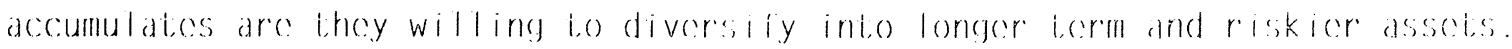

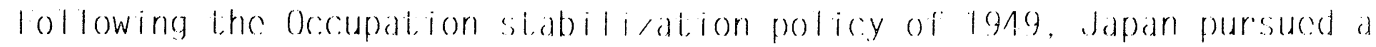
fiscal monclary policy mix of fiscal tightness and rapid moncy supply growih commonsurate with price stability. The government, budget, was balanced. government, debt, issue was negligible, and the ratio of government, debt, i,o cant was very low. this macrocconomic policy mix supporticed the modest role of the government in domestic demand and the contral role of private sccior finance, parlicularly bank loans, in funding business growith.

Sufficicnt political stability to reduce to reasonable levels uncertadintics about the major contours of major ceonomic: and social policices and the likelihood

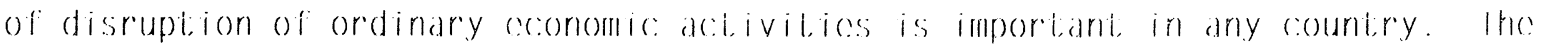
Japancese experience was exiraordinary in the decerese of politicad stabilit.y achieved in 195 bs by the alliance of moderate partices to form the l iberal Democratic: Party, which was in power continuously until 1993. Perhaps cqually important; in the high growth era was the widespread conscnsus that government: policy should focus on ceconomic: growth. a consecpuences in part of lihe dramatic: loss of World War II.

lecomomic policy on the whole premoled the development of a competitive cnvironment, particularly in product markets. Initially producers were proticciced from imports; casy contry nonclholess resulted in quite compotitive domestic: markets, reinforeced by the very sies and rapid arowith of the ceconomy. there were: less compotitive scotors, and some became increasingly so as the coonomy arew: agriculture and wholesale and reiail trade most notably. I abor markets were in principle free, but the cever growing demand of large firms for labor trained to 
their specific needs made the development of a permanchi, comployment systerm

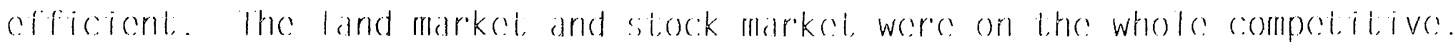

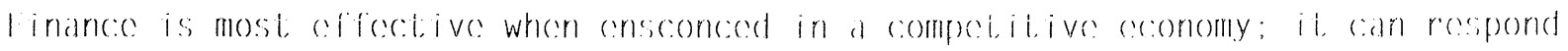

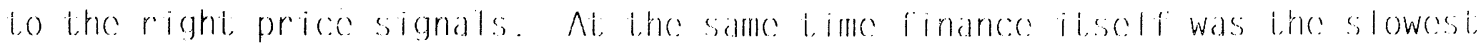

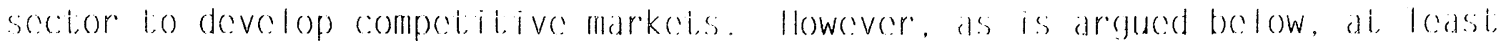
initially the regulatory restricitions on compeiti,ion were simongly suppori,ive of.

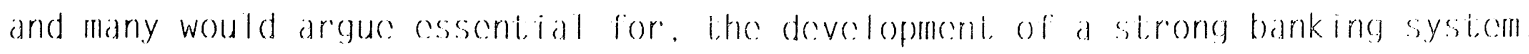

One consequence was the development of a producer or icniced socicity. bui. consumers and savers also bencifited conormous ly, if indirecelily. Japan's fast.

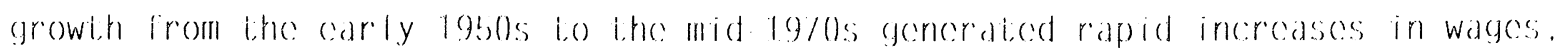
houschold incomes, and consumption. Japan's standard of living, despilie many problems, rose far mores rapidly i,han it, ever had before and more raphidly than any other country in the world during that time period. Intia well into the peredod. there was an implicit. social contracit wherebty houscholds accepted low yiclds on savings deposits and poor housing guality in exchange for a systerm that gencrated rapid growith in GNP and houschold incomes.

b.1.? The Siructure of the linancial system

The Japanese experience, and indeced that of all market, comomies, is that banks play a predominant role in business finance. Securilies markets become a significant source of large conterprise finances only in the 1980s. The polisey issue was whother large cnterprise finance, particularly for plant and cquipment investment, can be done ceffectively through a banking based systern. the dapancese main bank system, involving close coordination belwecn city banks and long tecrm credit banks, has demonstrated that it can. Morcover, it suggestis Japancese policymakers were correct in having rejected IJ.S. occupditon proposals to develop a corporate bond market as a major source of corporate finance.

Ihere are several strands in the andysis. I irst, the demand for

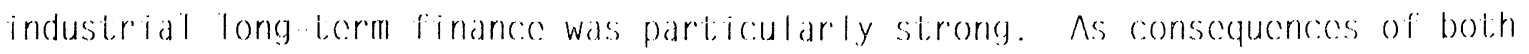
World War th destruction and their technology absorptive capabilitices. firms in large scale, capilal intensive ("heavy and chemical") industries were in a good position to develop profilable projects. Second, there was a lecrm mismatich. Savers were not prepared to purchase corporate bonds since their assets were limited, they well remembered the all too recont disastrous cffectis of inflation 


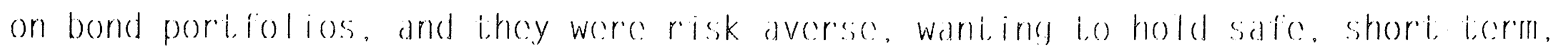
liquid financial assets. Ihird, information about corporations was limited and it,

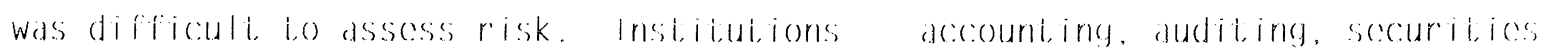

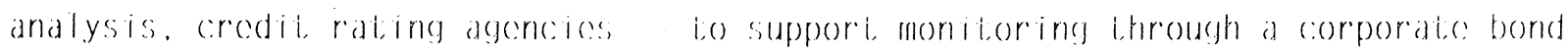
markei, were underdeveloped or non existent. Iouri,h, i,he human resource skills i.o cvaluate the coreditworthiness of large corporations and their projects to do monitoring were in very scarese supply. Ii. mades sconse i.o concentirate tiherm at a relatively small number of instibutions, namely the long berm ceredit banks and i,he:

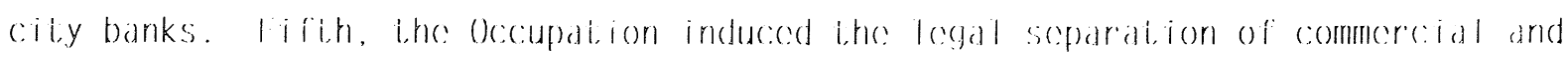
investment banking. Because prewar banks had underwriticen corporate bond issues. they still had the human capital skills, while ihe sccurritices companices (investimeni, banks) did rot, and peresonnel did not shifi. I ven il the bond issiue: market, had not becen repressed, it, is likely that ihe financial debenture of long term credit banks would have becen preferered to corporate bonds, so that the flow of funds, at least in the carly years, would not have becen so different.

lormally Japan established a system of commercial banking, unlike cermany's universal banking. Yet dapancese banking incorporated sceveral of the attributes of universal banking: cstablishment of a close long term relationship with large industrial clicnts; arranging of long berm as well as shori berm finance: colose

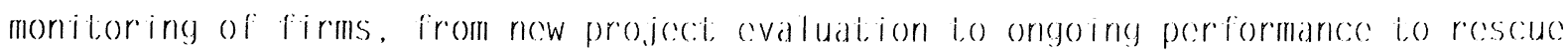
restructuring in limes of distress; and direcet invesiment, in the company's cquity.

there is no definitive answer whether the dapancese main bank mode: or the Gorman universal bank model is more appropriatice for developing market comomices and Isls. My view is that the dapancese model has the edge. Inderwriting sccuritices issue is not a major practical issue where sccuritics markets have not. yet developed inte a significant source of finance. It has becn argued that the Corman system involves coyicr, more self serving, oligopolistic relationships amoncy a small number of banks and large firms. One aspeci lo which many aitach considerable significance is the degrece of bank ownership of a company's cquity. Ownership cortainly has symbolis: value in Japan, with the main bank lypically the largest bank sharcholder of a iirm, but power lo direcily cexcercise control is much less clear since ownership was limited to $10 \%$ (reduced to b. $\%$ offective in $1.98 \%$ ). the relevant lesson is that allowing banks lo own non controlling shares in companies is desirable where it is an important colcment in developing and maintaining lihe colose bank corporation relationship. 
The dapancese banking systerm combediced a systerm of spocialieced financial

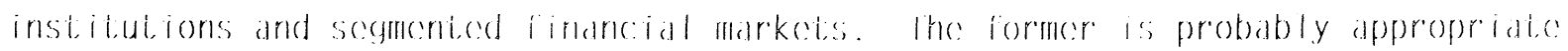

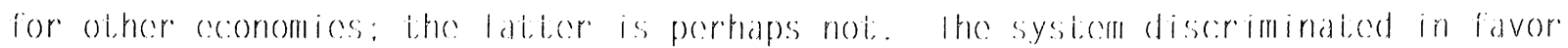

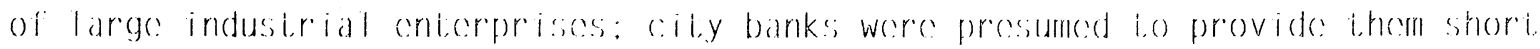

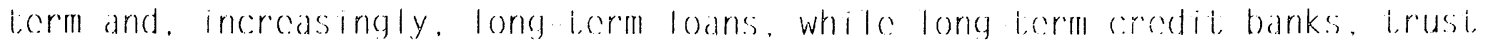
banks, and insurance companices provided longer lerem loans. Regional banks, mutiad banks and crodit associations financed medium and small conterprisces, agriculiural

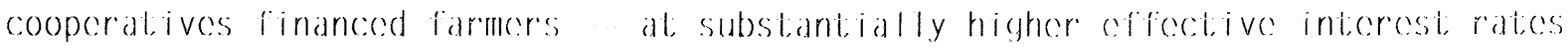

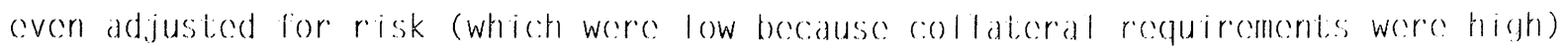

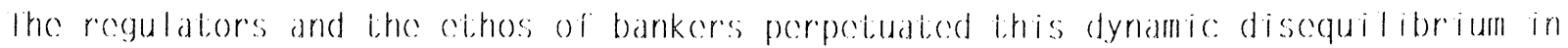

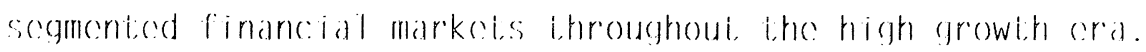

Markot cquilibrium andysis implios that small business conterpriso investment, was too low relative lo larege firms. Ihe counier aroument is that, large firms were key agcniss of growith as lhe importecrs and improveres of lechnology, and they diffused technology lo smaller firms. My prosumption is ihat:

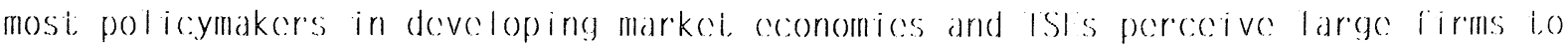

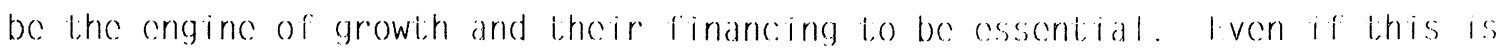
lirue, they should be aware of the necd not to distorl financial flows loo much

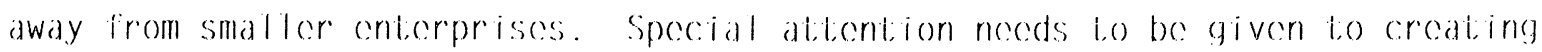
and providing incontives for financial instibui,ions that finarce small busincss activilicics.

Ihe threc dapanose private long term credit banks, cespecially the Industrefal Bank of Japan. played a crucial role in financing largo firm plani and cquipment, invesstment, not; only in providing funds bul, cespesially in project covaluation as lo croditworthincss. They worked colosoly with the citiy banks in syndicating lerm loans for main bank clicris. Ihis was an cffective division of

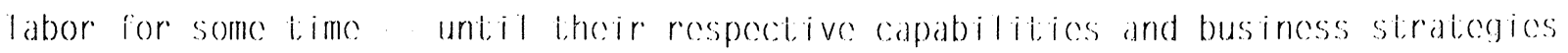
incroasingly converged, ospecially in the deregulation and casy moncy convironment. from the 19/0s when privale saving oubstripped privale investiment. Ihe dapanose expericnce suggests that a system of commercial banks and of long term credit. banks working logeliher is very cifocitive.

llow about lhe respeci,ive roles of privalely owned banks and other financial institutions and of government financial instilutions? In many countirics the government; owns the major banks and long lerm development, finance institulions. As a long run objecilive, lhat is a mistake in virlually all courltrics: it is 
930903

III) Re:levanus: 19

difficult lo insulate government owned (or contirolled institutions from the

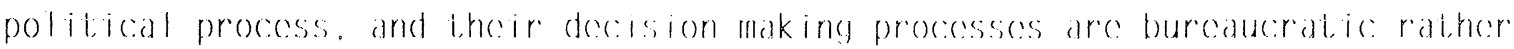
than market oricnticd.

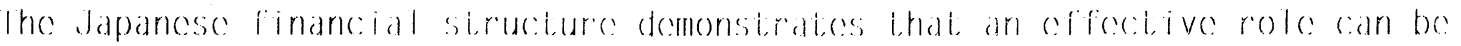

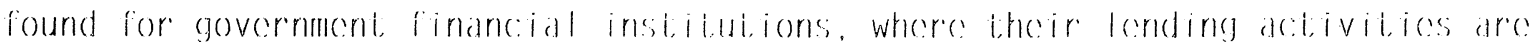
focussed. limited, and complementary i,o private linancial insididutions. Iwo

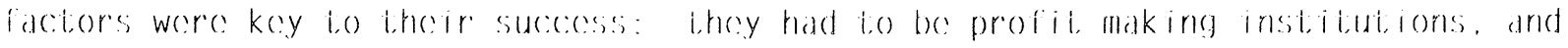
they had adtonomy from egovernment. bureducrabs and politicians in loan decisions,

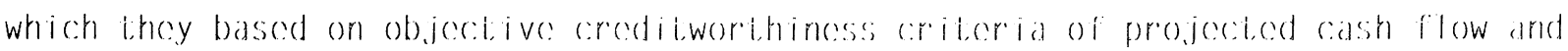
specific collateral. In lhis respece the dapanese lesson is cautionary. That ihe Japancse bevelopment, Bank is one of the very few casces of succossful government. development financial institiutions was not an accident.

An important reason for the successe of dapancese government financial institutions is that lhey had access to cheap funds through the government,'s postal savings system, where deposit, intereset rabices, as in privalice financial institutions, were subjece to low ceilings. Postal savings, utilizing ubiguitous post office branches, is a cheap), convenicnt and ceffective way for a government to mobilize privale saving. Ihere are, however, dangers. One is that posital savings become an casy way for the governmeni, i,o finance fiscal current cexpenditure rather (hannelling the funds to produci, ive provate business investiment. Japan avoided ihis pitfall. Another danger is that, postal savings depositis direcity rompotio. often on more favoratble lerms. with bank saving depositis, ihereby channel ing savings away from privalo financial sector intermediation. This has happened in Japan, in large part because the Pesital and lolccommunications Ministry rather than the Ministry of linance has had authority over postal savings.

\subsection{Iinancial Public Policy Issucs}

5.2.1 Deposit Safoiy, Bank Safoty, and Prudential Rocyulation

Public: confidence and trust in the banking systerm, and the financial system more broadly, are cescential for successeful financial developmenit. Particularly for houschold savers .... who ofiten are ill informed about the actual conditions and trade offs among risk, yicld, and liquidity of various financial asscis deposit. 


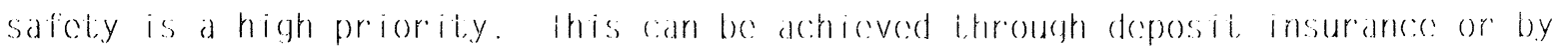
government guaranteces that, banks will not, be al lowed bo go bankrupt.

the dapanese government pursued a very conservative pol icy of guarantecenes banks against formal fature. While the guarantese was implicit. depositeors and indeced all financial market pari,isipants fully bel iseved that the reculatory authoritices would not allow a bank io fail, much less led deposilors take any

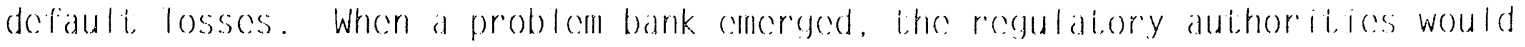
intervene and, where necossary. merge it, intio a sitronger institution. Any bank

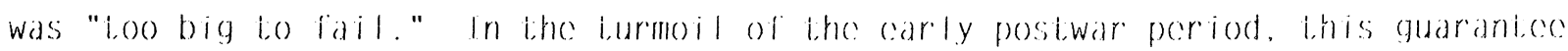
was cessential, and highly cefocetive: an additional suarantece of depessit insurance was of marginal sicunificance.

One dilemma of such strong bank safoty guaranteces is that they incercase thes moral ha/ard of banks laking excesssive risks. lo prevent, this, and to reduce the government's financial exposure, the recgulatory authoritices have a range of policy options. Ihey can require high minimum capital asset ratios, excreise strong prudential regulation and effective supervision, or cnsure bank profitability through constraints on competition. Ihere is a danger that measures taken to restrict competition will rosult in rent scoking behavior and credit. misallocition.

Japan logislated but did not conforce high captial adecquacy rules and actual ratios were low. A basic: problem was that cequity capital was short and the only ceffective way to increase bank captital was through redianed carnings. achiceved by making banks profitable and resiricting dividend pay out. dapancese policymakers did constrain the terms of bank compotition by restricting contry. scemonting markets, and sctiting a coiling rate on deposits sufficiontily low t.o make deposit based lending very profilable (bui, sulficicnily high, combined with favorable lax treatiment, lo prevent; potcontial depositors from fleceing to real assets).

prudential regulation and ceffective: supervision are cesscntial in any banking system to prevent fraud, excessive risk laking or other forms of bank mismanagement, and to conforce rules designed to chance bank safoty. Japancese regulatory controls and supervision were very cffective in the high growth cra in consuring bank safcity and good performance. Ihey were criforced both by valuable. incontives (cheap central bank loans, new branch of fice licconses) and potconi,ially

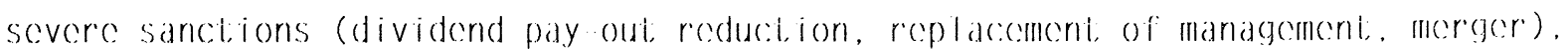




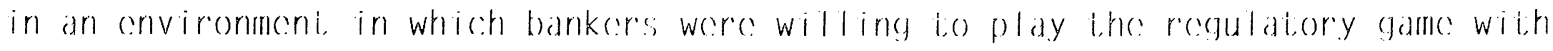

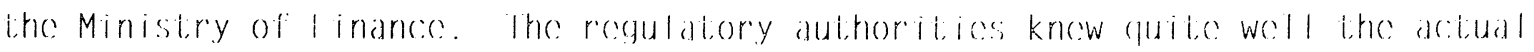

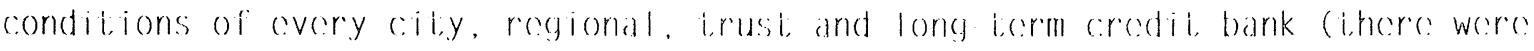

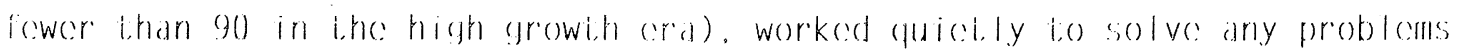

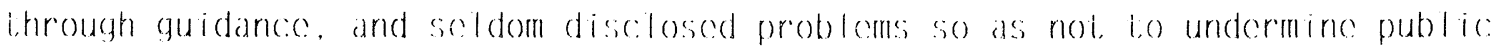
confidence.

The Japancese public: trusted the power, authority, and honestiy of the Ministery of linance and the regulatory framework and its administration. One cost. was that it made possible a very non transparent system of regulation by administrative guidance and informal negotiations betwecen the banks and the Ministry of linance, in what became cosy, non arms length relationshipses. In countries where the public: may be more skeptical of government burcaducrats and as a long run objeccitive ceven for Japan, a iransparent regulatory systen cortainly is highly dosirable, perhaps necossary.

\section{5.?.? Iow Interest Rate Polic:ics and linancial Reprossion}

Japancese expericnce provides i,wo important I cessons concerning financial repression. lirst, in comparison lo many developing market comomices and isls, the degrec of Japanose financial repression was limiled and modest. Coiling interest rates were positive in real terms. lmportantly, banks were able to adjust loan ratos closer to market rates by requiring compensating balances, thercby reducing the likelihood of credit misallocation and renti sceking behavior. bespite rostrictions on cntry there were a significant number of banks. cspecially in the large conterprise loan market, so that a reasonably competitive convironment, apparentily cmerged. Banks were insulated from political and burcaucratic: pressures in making specific: loan decisions. In sum, dapancese policy and bechavior apparentily kept lihe adverse ceffectis of even the modest degrec of financial reprossion to a minimum.

Second, low interest ratos, the wide interese rate spread, and the: restrictions on competition effectively subsidied the strengthening of what, in the carly 1960s, was a fragile dapancse bank system. In this respect the ronts from limited financial repression were used bencficially for institutional development. Many, Lhough by no means all, exportis on Japancese banking and financial markets decm this support to have becn cesscntial for the building of a 
9309093

III) Re:levance: !)

strong banking systern and, by exicnsion. a sitrone main bank systerm. It also has

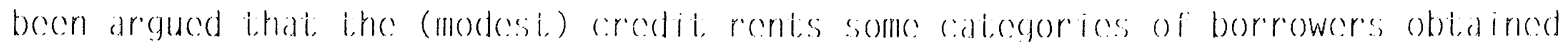
were consiuctively indexed io objeceitive, performance conhancing indicators.

If the prescnt siluation in a developing market ceonomy is that the degrece

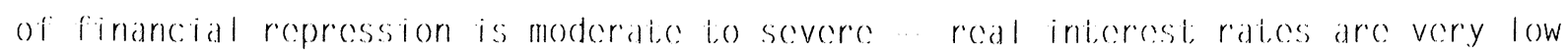
or negative, competition is limited. and coredit rationing is substantial i,hen the Iesson from the dapanesse experencenes is that less financial represssion is better. Ihe trade of between the benefites of instibitional development and the: costs of credit, misallocation and reni, sceking behavior have to be weighed carcefully, and the bendency to excesesive financial repression resistied. Morceover. over time as lihe banks bocome stronger. the neced io substide insititutional support decreases and accordingly lhe degrese of financial repression should be reduced. 10 some cexicni this occours i.hrough market forcess as financial market participants find loopholes. In addition the government will find it desirable to pursue policies of financial derecgulation and liberalization. One danger, as was the case in Japan, is that deregulation will be delayed because of burcaucratic: incritia and desire to retiain power, and the creation of vested interests in the regulated system.

\section{!. 2.3 birected credit.}

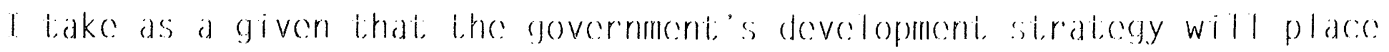
priority on cortadin activitices, which will be subsidied in various ways including

preferential allocation of credit at lower interest rates. The issues involve the type of activity, the degrece of subsidy, the nature of the credit allocation mechanism and process, and the potential inflationary conscequences of the funding procoss.

The dapanose government dirccled credit i,o promote: exports, build physical infrastructure cesscntial for industrial growth, and develop cortain strategic or largeted industries. In comparison with similar programs in most developing market coonomics and ISts, these dapancese: subsidices werce relatively low.

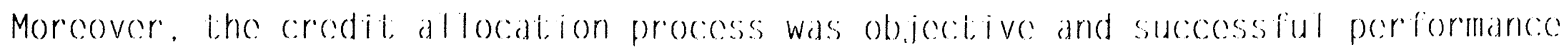
was a requisite for continued support. lxport trade credit and loans for cxport production were not differentially subsidied by sccior, with the exception of lixport Import: Bank lerm loans for sales of ships and machincry. Infrastructure 


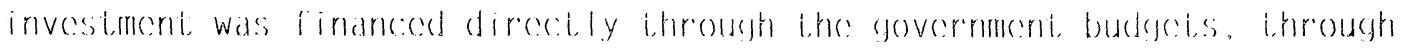

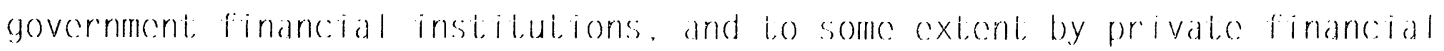

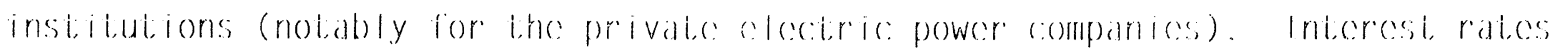

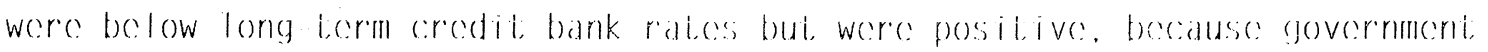

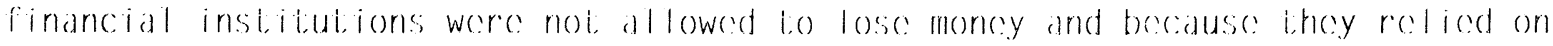
postal savings, which sot a floor on lhoir fonding ralos.

the role of industrial polis:y in the development processes is mores controversial. So too is delated cevaluation of dapan's experricnes. Ihe most significant facts of the Japanese expererence are that while some of the winner industries of the high growth cra obtained directied credit, obihers did not, and

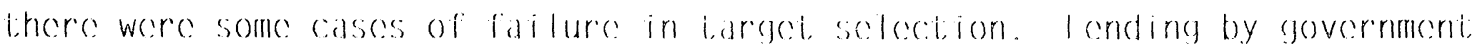

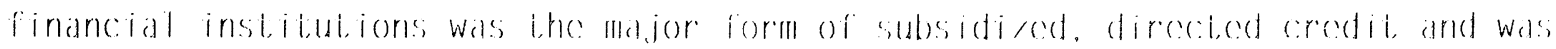

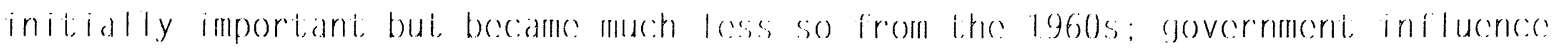
over privale bank lending was indirces. relying on the financial structure and it.s incentives rather than on direcily controlling creddit allocation: and while: industries were targeted, specilis: firms within them were subjecet to standard credit cvaluation and project analysis. A major proporition of directed coredit for plant and equipment investment, in the 19t0)s went to four industries . . iron and stecel, clectric: power. marine shippine and coal mining. Iwo of these w... shipping and coal... becane incfficient. dectining industries from the 1960s, and absorbed a large proportion of Japan Iecvelopmeni liank loans becausc privale banks judged them unatitractive. In the 1960s the proportion of taregeted in totial plant and cquipment investiment finance decreased substantially, and was not, significant thercafter.

The basic: foalures of Japan's direceded ceredit policy dedermined its success, and are direcily relevant for other countries. They included: a relatively broad targeting concept: (industries not, firms); credit allocation done by bankers using objective corcdilworthiness criteria; litile interforence by government officials or politicians; posibive real interest, rates, with relatively modest degreces of subsidy; implementation primarily through government; financial insititutions: reliance on private savings mobilized through the postal savings system; and utilization of the private institutional structure of long term credit: banks, city banks (cspecially to their main bank (:licnts), and trust banks for the provision of long term finance. A further, important lesson is that government; financial instititions and their managerment must be held accountable. In Japan 
9.3090 .3

III) Rolevaric:! : 1

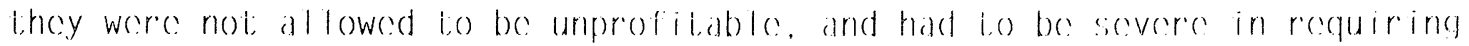

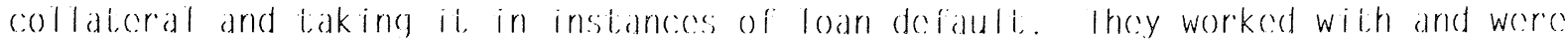

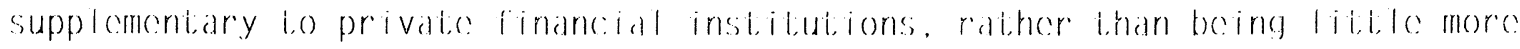

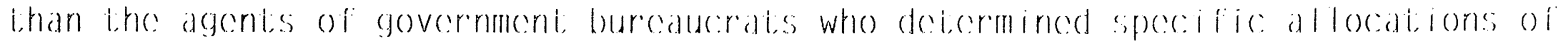
"polic:y loans."

๖.? A Avoidance of Rent Sock ing and Corruption

Policymakers must confront ihe reality that in some coonomics corrupt, ion is a serious problem. In the financial sphere, opporiunitices for reni sceking and

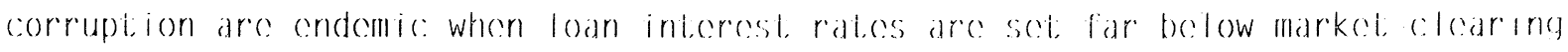

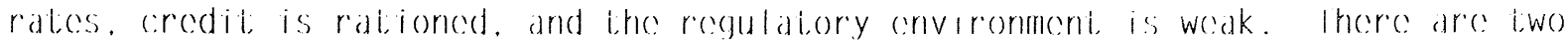
lovels of problem: individual and inslibulional.

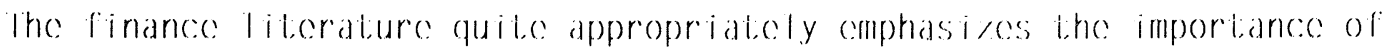
prudential supervision and of transparconcy io provont individual banks. firms, or persons from congaging in excessive risk laking, favoritism, insider cxploilialion of asymotric information, fraud, payment of bribes lo obtain rationed ceredit. on favorable torms, and the like. Institutionalized corruption is more systemic in nature: it involves the financing of politics and the political loadership through illegal contribulions and payments in exchange for politicial and government. official decisions lo have corcotil allocaled on preferential lorms to favored firms. In offece credit rents are cereated by government polic:y, and used in part. io support the government Ioddership. Ihis is the central political coonomy issue of finance; il has not becn subjecit to cxicnsive compirical rescarch for obvious roasons.

Ihe most cifective way lo doal with corruption is to coliminate credil (and other regulatory) rents by promoting a high degroce of market compcitition supportacd by an appropriate legal and institulional framework. Ihis sharply reduces the opportunity for reni, sceking behavior. llowever achicevement of a highly competitive market coonomy is an ideal, and cortainly will not be achiceved

overnight, In finance, the degres of corruption is directily redated to the degree of financial repression, which croates the rogulatory corodit rents.

linancial repression in dapan was modest and limiled. Crodit ronts were rolatively low, and specific credil allocation decisions were insulated from significant political prossure or burcaucratic inicerference, and were made by 


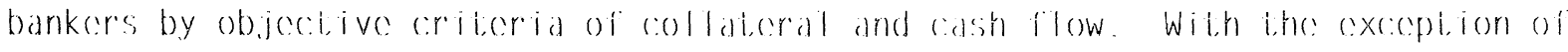
government financial instibutions. cefocetive intecrest rates on loans weres only

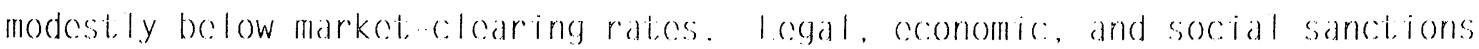
againsi, various forms of morally hadardous behavior weres severe, prudential regulation was strong, and bank supervision was cffecetive. Ihose are the lossons for other rations.

Ihus, despite a few notable scandals, i.he Japanese financial system by and large has not; becn subjecet to individual corruption. The degrec of insi,itutional corruption hidden illegal donations to politicians and political partices by financial institutions has not becen pereseived by mosi, Japanese i,o have becen an intolerable problem. However, ihis is a murky area. Ihe nature of the relationships between dapancese banks, larege and sfllall, and politicians, national

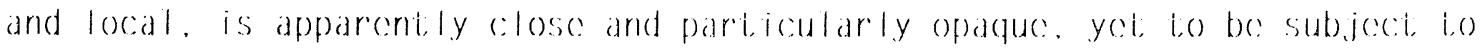
substantive investigative reporting. It is worth noting that none of the scandals of recont ycars regarding the tiransfer of regulatory rents by businesses to politicians and burcaucrats (government procurcment, i, ruck ing route licenses, terms of tpo issue) have involved banks.

b.3 The Main Bank Systen as a Model for linancing I arege Industrial Interprises

In any market based financial system banks play a major rolo, cocriainly in the financing of small and medium firms and, except, for the Inrited States, in the financing of large industrial cnterprises as well. the Japancese ma in bank system cpitomizes in many respects the sucecess of the Japanese banking systicm in mobilizing savings, and allocating them effectively through loans to busincess. particularly large cnterprises. It is an especially appropriale model for bank financing of large cnterprises in many developing market and transforming socialist conomies.

The cesscntial foatures of the main bank model are micro. li is a low cost, cfficiont and effective institutional solution to the problems of costly. imperfect, and asymmetic information about borrower creditworthiness, given the reality that markets are not perfectly competitive and completic, and cannot, be (Stiglit, 1991). In a market based corcdit rationing model Ienders classify. albeit imperfectily, borrowers into catecgories by degrece of risk (creditworthiness) 


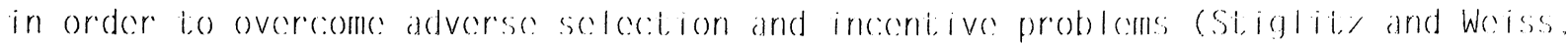

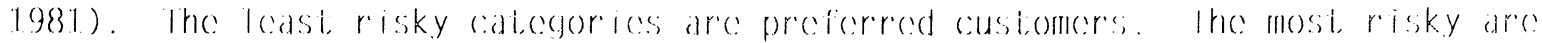

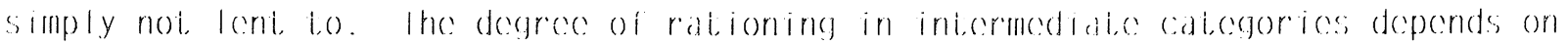
the supply of loanatole funds. the quality of information for coredit andysis, and

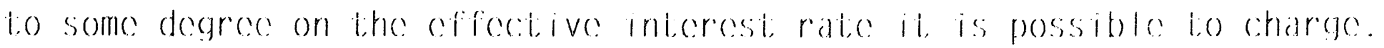

In a regulatory model of credit rationing, government, influches on the cffective interest rate has some significances on the terms of bank loans; and its policies or signals indicating which activitices or industrices are of high or low priority influence bank thinking as to which catcegories firms should be assigned. A regulatory ceredit, rationing framework chlancess the power of the bank vis a vis the borrower, by widening the gap betwecn demand and supply, and makes the: cstablishment of a main bank relationship ceven more valuable to both bank and firm.

As is stressed throughout this book, the cessence of the main bank systien is the ability of the bank to monitor cffectively and to arrange for fundeng for lhose large industrial clicnts with which it has a particularly close and sustaincd main bank relationship. The citiy banks worked closely with the long lerm credit, banks in new projocet cvaluation and provision of long icerm fundine through the main bank relationship. The main bank took responsibility both for gathering and producing information on the ongoing activities of its clicht and for providing the clicent information and advices (in ceffect, mandgement, consulting services) to contances conterprise performance. li, also took responsibility for and a disproportionale share of the cost of, rescuing, restructuring, or liquidating a firm in distress. Ihese monitoring functions are cessential in any financial system. They constitidie the core of what can. and in many cases should, be transferred to other countries as they develop their own banking systems.

Ihe most distinctive foature of the dapanese main bank system is it contral role in the restructuring of targe firms in distress, at considerable cost to the bank. This has proven to be a cheap and cffective restructuring mechanism. Rescue is by no means automatic: the main bank makes a rational calculation as i,o whether the firm is worth more by liguidating its asscis or by restructuring its activitices and financial position and continuing it in operation. I iquidation is a complex and gradual procoss, ultimately involving merger into a stronger firm without going through formal bankruptey. The bank recpuires a detailed financial and business plan. into which its own staff provide significant input; it has the 


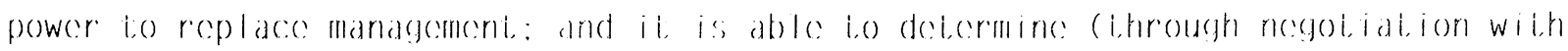

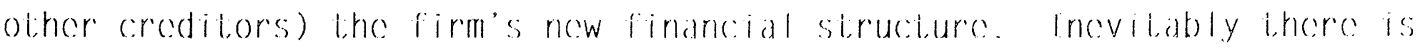

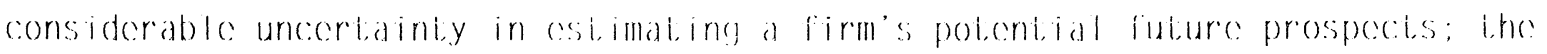
prosumplion is that a close main bank relationship cosures the firm will bes troaled more gencrously than soverely within that range. Iho groal danger is ihat. of soft budgeding, of providing mew funds for the comitimed operabion of firms

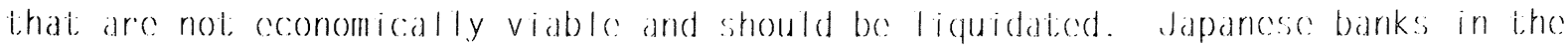
high growith cra avoided ihe problerms of sofit budgei,ing, with only a fow mistakes.

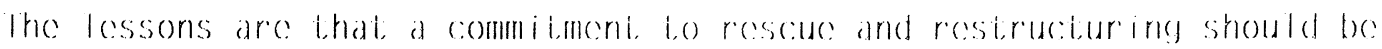
conditional upon coonomis: foasibility. ihe restruciuring should be carefully

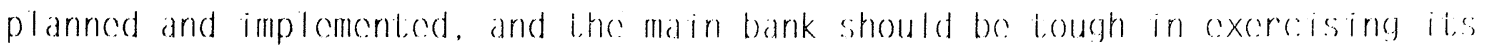
lodership bolth vis a vis iho firm and obter corcdilors.

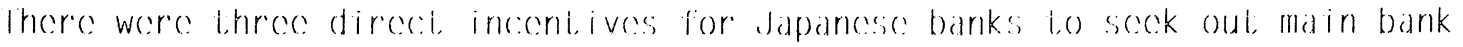
rolationships. The most importiant was the rent (or recturn) derived from investing in information aboul, lihe borrower, and hence the reduction in reisk premium for good borrowers. The necd to recoup moniloring costs ceven in a rolatively compotitive short term loan market, was cased by the system of dolegated monitoreing among banks. Second, ihe main bank received proference in providing various lucrative financial services to the borrower, including transacitons deposits. forcign exchange business, trustece and obher foe business, and the businoss of

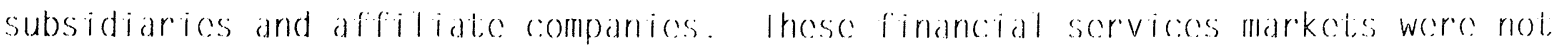

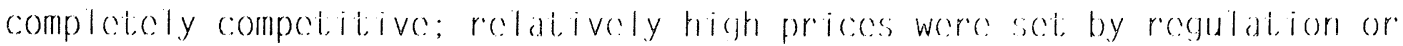
oligopolistic betavior. Ihird. main bank ownership of corporate conterpriso cquily, ceven in the rolatively limiled amounls allowed, provided incentives lo and bencfils from monitoring (Kim, 1991). and signalled the ciloscress of the relationship. lurlther, it can be aregued that lhe regulatory framework and the modest degree of financial reprossion cefocelivoly subsidied iho instibutional strengthening of banks in general, and made them more willing and able lo develop main bank rolationships. Cortainly the main bank system, which covolvod in

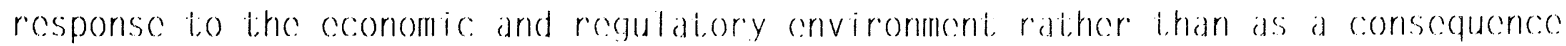

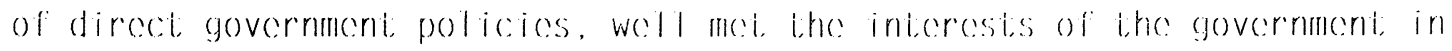
promoting large conterprises as ihe congine of growith. 
The relevance, uscefulness and transferability of the Japancese: man ha bak model has to be placed in the comtexi of a brodder range of issues of finance and banking development. and how they are resolved. Morcover, an effecitive main bank system cannot be cercated overnight. As with olther types of institutional development, il lakes lime for learning, development of skills, creation of knowledge, and growith.

One issue is the governance of the large banks that will be chegaged in ma in bank rolationships. Who owns the banks? Who controls bank polic:y, both of basis: business strategy and of specific: loan decisions? Concentirated ownership makes for shareholder control. Ihe new preivatiadion of Mexican banks places ownership and control in the hands of business groups. Will prudential regulation be cffective in preventing the owners from manipulating bank lending for their own bencfile? In India commercial banks and development, banks are owned by ihe government; they are burcaucratic: and far from celficicnt. In chind and poland lihe. banking systems are government, owned and nascent. In korca bank cquity ownership is dispersed, while control lo a considerable degree has becn vested in the government: which has had a dominant influcnes on bank policies, ceven at the level of cortain specific conterprise and business group loan decisions. In Japan bank ownership is widely dispersed (except for a fow small banks) and in normal circumstances management has great autonomy within ihe general parancters and guidelines set by the Ministry of linance.

Management autonomy, a feature also of most large Japancese industrial cntcrprises, has worked well in Japancese banking. Iheir incentives and sanctions. and insulation from politically molivated government prossures or scif serving pressures of concentrated stockholders, have chabled them i.o allocate credit offectively. Yot it is by no means clear that mandagement, automomy in bank governance will operate nearly as cffectively in different institutional and policy crvironments. Ihere are dangers in a self serving managencent, expropriating rents for their own bencifit. Perhaps the most significant lesson is that bank governance is an important maticer since what is at. stake is the efficiont operation and effective credit allociation of banks.

Related both to corporate governance and the structure of the financial system is the issue of where scarce human cappilal in banking skills should be: 
concentiated inilially, and how they should be cexpanded and diffused over lime. in carly postiwar japan, project colduation skills were initially concentrated by

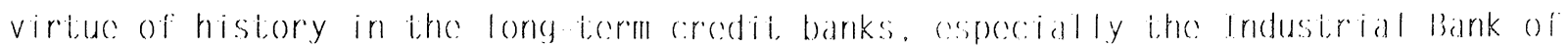

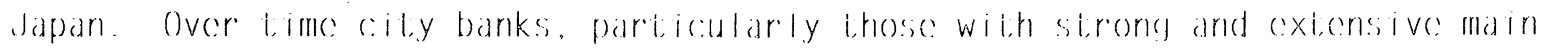
bank rolationships, developed project, covaluation skills. Ciliy bank sitaff had some skill in monitoring the ongeing operations of their colicnis; over time.

particularly through the recguirementes of the: ma in bank rolationship. i.hey buili, up those skills. Ihose wilih a substantial number and range of main bank rolationships also developed skills in rostrucituring clicnis in distross. accumulating learning by doing and documenting. The lossons suggested by Japancese experience is that scarces human skills might initially be concentrated in a rolatively small number of insititutions, that skilled personnel should be i, raned up, and that over time they should be diffused amones a sufficicntily large number of non governmental institutions so that information quasi rents and oligopoly market, power are reduced.

The main bank system is offective in overcoming problems of project cvaluation and lack of information about a clicnt"s creditworthincss. Nonctheless, where the basice information is weak or where banking skills are lacking, asset based lending is a conscrvative complement lo we rather than substitute for .... cash flow and other techniques of performance analyses. I)uring the asset price boom of the late 1980 s assot based lending dominated cash flow analysis for many real cestate projects; the cepcectation was that pricess would only go up), which has proven to be an incorrecet and costily assumption.

the Japancse banking system since its modern beginning in the toth contury has had a history of requiring specific collateral for loans, particularly longer term loans, and of selling that collateral when loans were defaulted. bespite

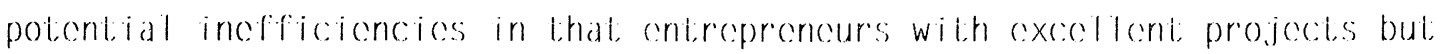
inadequate collateral are rationed out of the credit markei, requiring collateral chhances bank safety and reduces borrower (and lender moral havard; in many

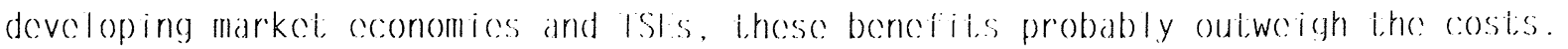
An coven more conservative approach given high risks, cespesially in lsts, is infitially to limit corporate finance lo equity ownership, ihen non bank lending. and cocntually limited fully collateralized, sclf liquidating short term loans (Mckinnon, 1991). 
The main bank systern is a particularly iniconsive and colose form of rolationship banking. The relationship in Japan is multidimensional and comprehensive, including cauity ownership, is based on substantial trusi by both

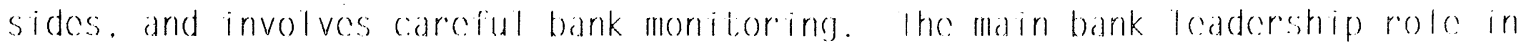
rescue and rostructuring of a firm in distresse is an imporiant distinative: fodture. As so defined, the main bank system applices in dapan only to line financing of large indusirial corporations listed on the stock exchanceses. Smaller companies have a less inicensive form of relationship banking which they also refer lo as having a main bank. but, he bank ex ante commitment, i.e rescue and restructuring is limited if it, existis at all. But this doces not mean that ihe financing of small busincess is unimportant. Quite the contipary. In the hoth growlth cra and ceven at present, smaller. non lisiced firms produce most. manufacturing output and other industirial value added and are the predominant, source of employment. One way or another, their growth has becen financed. the lesson: policymakers must recognie the role of smaller conterprises, and consure that the financial structure provides funds to carry it out.

the main bank system can and does work well in a derecgutated, competitive financial cenvironment, as shown by the dapanesse experience since lhe mid 19/0s. It was the major main banks that pressured the Ministry of l inance to deregulate. Under changed domestic: and international market conditions they saw new opportunitios and beliceved (correcel,y) in their superior abilities bo compedice Ihey had to adjust to the shifi,ing of some major clichts to sccuritices market issue from bank loans, and the main bank rolationship with some of therm looscened and changed form.

Does the main bank system represent an intermediate stage of large conterprise finance, in place only until conomies grow and mature and securitices markets become the more cfficicni, mechanism? looking to Japan's future, in my judgment the development of a more competitive convironment and the rise of an cffective sccuritios issue market, will not result, in the demise of the main bank systicm, but will transform it, somewhat. A subscti of very targe, succossful, Japanese companies no longer need a decp, substantive relationship with a main bank: they are able and willing t,o finance internally or to ui, iliec less cexpensive sccuritios finance. They will become increasingly independent. Yot many large industrial companies will want lo continuc their woll costablished main bank rolationship for its mutual sharcholding and financial scrvice fodiures. Smaller 


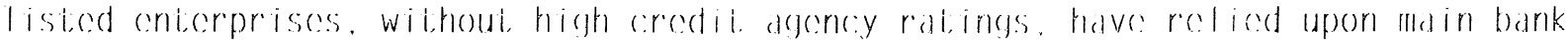

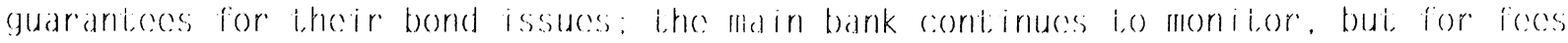

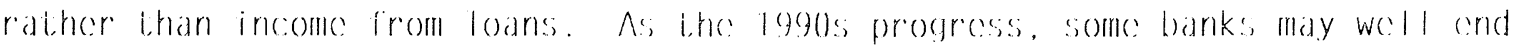

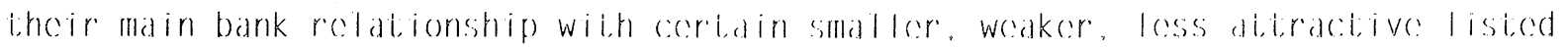

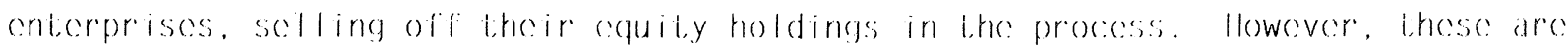
the companies for which main bank monitoring scrvices creatic i,he most value, so the main bank rolationship is likely i,o be shificed from one bank i,o another. (Inly those companies where the risks (and costis) of polontial distross are hich will be? excluded from (rationed out of ) the main bank system allogether. Ihey will ihen be policntial candidatos in an comergent, lake over market. on the other hand, banks are likely to scek out new main bank relationships, includines cequity holdsings,

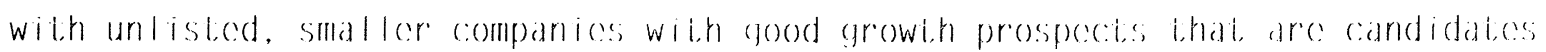
for publis: listing (ladeker. 19933) Ihus, the main bank monitoreing function will continue i.o be important for all but a relatively small proportion of large companics.

\section{3.? Special problems of the Iransforming Socialist l conomices}

The transforming socialist conomics can learn much from the Japanose historical, instibutional, and policy expericnece of financial development and growtith. As they succecd in making the transition lio market coconomics, Japan's high growth cra will be particularly relcevant. In their process of transition the ISlis face many problems similar to those Japan had in the carly positwar perriod of dislocation and transibion lo democracy and a markcie cromomy. Japan had lo deal with scvere problems of shifting from armaments to civilian goods production. rampant, inflation, very limiled trade and siringent, exchange controls; a virtidally insolvent, banking system, and many insolveni large conterprises due i,o a horrendous bad (government repudiated) debt overhang. How Japan solved these problems offers insightis into good macrocconomic: policies and to lihe resolution of soft budgeting and debl overhang difficultices (sce loranishi, 1993). Ihore are major differences to kecp in mind, however. Japan had a long expericnece as a private markot coconomy and a quite well developed institiutional infrastructure, only bricefly interrupted by wartime controls and coconomic: planning. It had a reasonable supply of human capilal skilled in commercial and development, banking. The carly postwar Nllica occupation was an external forces which could impose promarket, pro democracy 


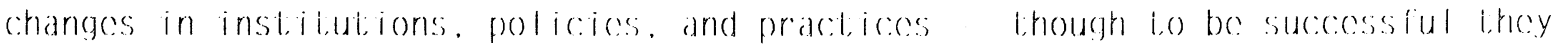

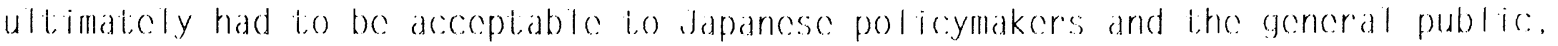
as in fact almosi, all weres.

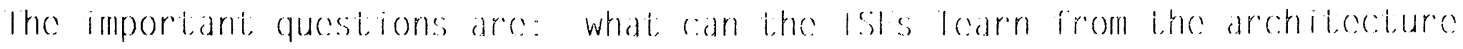

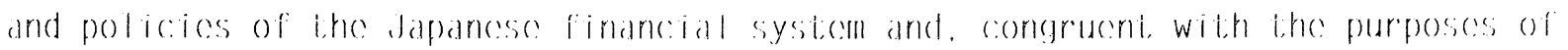
lhis study, from the main bank system? Ihe answeres depend on the particiular problems policymakers face in each lst, as are woll rofleceled in the chapteres on

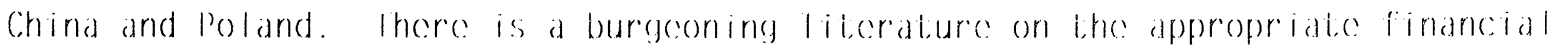
archilecture and policices for ists. much of it generabed by the world bank (sece for example Caprio and lovine, 199\%, as woll as Mckinnon, 1391). Il is beyorid my

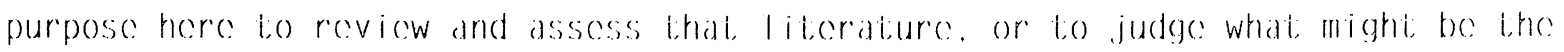
best model of financial struciure and polisy for lsis.

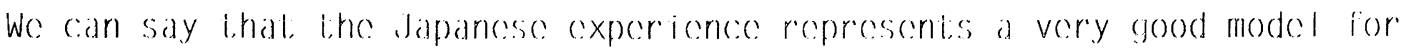
the ists in several csscritial respecis. li is a banking bascol system … and at. this stage of Ist development, banking is a moro cificicont mechanism for industrial finance for large colerprises than the sccuritices markct (corbetit and Maycr, 1997). Acitive silock markcis apparconliy will devolop rolativoly carly in many istis as a rosult of the privatioalion process of large stade conterprisos. Ihose are l ikely to be l, rading markets, usceful for slockholder liquidity and for the function of price discovery. However. they will not be markets for substantial now fund raising through conterpriso stock or bond issuo: tho

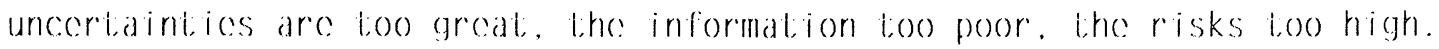

Bank monitoring, as based on lho dapancse main bank model, will more officiontly and offectively overcome informalion problems for lenders, and in the procoss instrucit conterpriscs in the basics of cash rlow and ysis, cost acoounting.

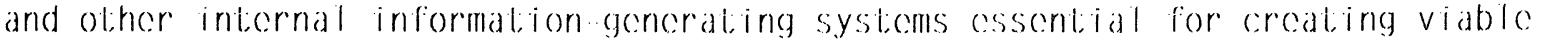
firms. The croation of sccuritios markcts will facilitate the cefocitivenoss of a main bank system by more roddily providing tho opporbunity for bank ownership of conterprise equity, lihereby sirengthening the incentives for decp monitoreing and for commitment lo lake the leadership in roscue (or liquidation) of firms in distross.

ISt:s have lwo particularly importiant problems: the overhang of static conterprise accumulated bad debti, a problem compounded when i.he debi is held by financial instibutions ralther lhan lhe government; and continued financing of conomically non viable large conterprises (sofl budgeting) for political, social 
or other reasons. Ihe banking systerm, or a main bank systerm, cannot, solve these: problems; they are cesscritially political in nature. Mosi of the costes of accumulated past bad debtes will have lo be absorbed by the government (socicity). If non viable conterpreses are to continue to recesive financial or obther subsidies, it. should be done dircedily through the: gevernment budget raither than indirecity (and oficon in hidden ways) through financial institul,ions. If banks (or any financial institutions ) are lo be ceffective monitors and allocators of coredit, they have to be prepared and able lo deny funding to poorly performing cnterprises, whether statie or privately owned. Ihis may well be the greatest. impediment; to developing an ceffective banking systeon in ISls. A further dilomma is the lack of human skills: many financial officers in lsts have cepericneced only soft budgeting, not hard.

How much control over large industirial conterprisces should banks have? Ihere is no casy answer; the financial architects for cach ISl will have lo answer that based upon the particular country's circumstances. In the carly stages there is probably some danger of too litile control, of relatively limited relationships and monitoring. Ni the other extreme there is very much the danger of too great control, cither by the banks themsclves or, more likely, as instrumentis of the government; (for example, Korea and India). In betwecn the extrences are the Japancse main bank and Cerman universal bank models.

the choice betwecn Japancese and cocrman models of very colose relationship banking will depend on a country's speccifics of history, instibiutions, and values. What can be said is that the Corman and dapanose types of bank based finance are similar, and cach has performed well in its own context.

The main bank system is not a pandeca. lorm without substance is usually a recipe for disaster. to be successful it must be bulitressed by appropriate policies and behavior .... good prudential regulation and offective supervision, compotibive financial as woll as goods markels, and sirong sancitions againsi poor performance. A very real problem is l,o devise a structure and policios that minimi\% opportunitices for rent secking and corruption. Iven aside from information asymotiries, the transition process in tsls has becen creating huge rents in the arbitrage betwecen regulated and markei, prices, allocations by liconsing and rationing (cspecially credit rationing). Lhe privatidation procoss of state conterprises and assets, and the like. 


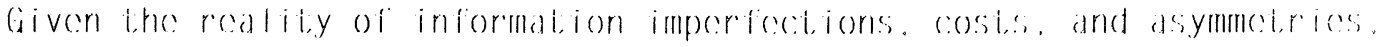
instibutional mechanisms for monitoring within and in supporti of a gencrally compeditive convironment are esscrntial. Ihe Japancese struciure of a doen or so

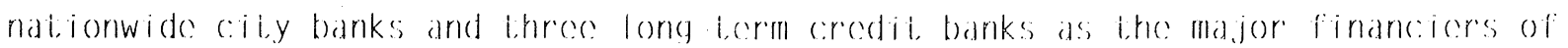
large conterprises led lo workable competition despite some constraints and

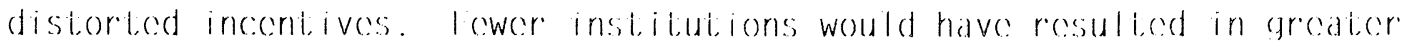
oligopolistic bohavior. A further lesson is the importance of the constraint that all financial institutions gevernment owned as woll as private c... be: profiliable.

What has worked for dapan is what, works ceverywhere: i,hrili, honcesi.y, hard work, coducation, property rightis, a willingness to sacrifice for tomorrow, and strong familios that lake good care of children. (Rauch 199\%, p. 110).

There is no magic to Japan's comomic: and financial success. The Japancese financial system and its main bank system have cevolved over the past 10 ycars and more in response to coconomic: development and growth. occasional profound shocks. and the decpening of financial markets and financial intermediation. Ihe systems also roflect basic government, decisions aboui, the appropriate financial structure and the financial policies to achice broader developmential objectives and to support the financial systern. lor the developing market coonomies and the transforming socialist comomies, Japanese cexpericneces of carly postwar and ihe high growth cra to the carly 19/0s are particularly relevant and usceful.

the problems and difficulties the Japanese financial system and it,s banks face in the 1990 s in the aftermath of the bursting of the speculative asset boom bubble of 1986 90 do not undermine the fundamential lossons of the dapancese case. What that cxpericnee demonstrates is that ceven strong systems and institutions, not only banks but their regulators, can fall prey to collective myopia and that greed in periods of speculative mania can outweigh rational, conscrvative. calculation of project viability, borrower creditworthiness, and collateral value. for policy purposes in other countries, understanding of Japanese finance. should be at lihrec levels: how the Japanese system operated: within it, how the 
banking system operated; and within that, how the main bank systerm of cilose and special relationships with large industerial cnterperises operaled. Ihe lessons are both positive and cautionary.

While the minimal package of institutions and policeices necossary for an

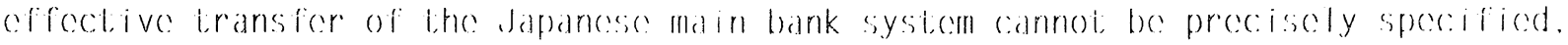
as a practicial policy matier that may not be necessary. A greati deal depernds on the financial architecture and financial policsos being pursued in the transforring country. Vory fow are now pursuing policaices whereby interese ratos arc market determined. contry is relatively casy, a bond issuc market, is concouraged, and financial marked, competibion is vigorous. Nlihough there is a debale in principle over lhe benefits and costes of dapancese policios of low

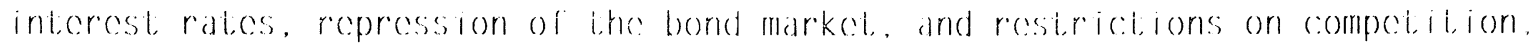
from the perspective of developing market concmies and the Ists the important, points are that the Japancese degrese of financial repression was modeste real interest rates and other incentives were positive, there was considerable competition, credit allocidion was done by objective, efficicncy based criteria without substantial outside intereferences, and corruption was low.

the most important lesson from this study is that the Japancese main bank system is not; only a relevant and usciul model for large industrial conterprise finance, it may well be beticer for developing market coonomics and transforming socialist conomices than other models. 
Anchordoguy, Marie. 1989. Computers, Inc.: Japan's Challenge to IBM (Cambridge: Harvard University Press).

Aoki, Masahiko. 1988. Information, Incentives, and Bargaining on the Japanese Economy (Cambridge: Cambridge University Press).

Calder, Kent E. 1988. Crisis and Compensation: Public Policy and Political Stability in Japan, $1949-1986$ (Princeton: Princeton University Press).

Caprio, Gerard Jr. and Ross Levine. April 1992. "Reforming Finance in Transitional Socialist Economies, " World Bank, Country Studies Department, Working Paper 898.

Cargill, Thomas F. and Shoichi Royama. 1988. The Transition of Finance in Japan and the United States: A Comparative Perspective (Stanford: Hoover Institution Press).

Corbett, Jenny and Colin Mayer. 1992?. "Financial Reform in Eastern Europe: Progress with the Wrong Model," Oxford Review of Economic Policy 7 (4).

Dore, Ronald P. 1986. Flexible Rigidities: Industrial Policy and Structural Adjustment in the Japanese Economy 1970-80 (Stanford University Press).

Friedman, David. 1988. The Misunderstood Miracle: Industrial Development and Political Change in Japan (Ithaca: Cornell University Press).

Fry, Maxwell J. 1988. Money, Interest, and Banking in Economic Development (Baltimore: Johns Hopkins University Press).

Genther, Phyllis. 1990. A History of Japan's Government -- Business Relationship: The Passenger Car Industry (Ann Arbor: Center for Japanese Studies, University of Michigan).

Gerlach, Michael. 1992. Alliance Capitalism: The Social Organization of Japanese Business (Berkeley: University of California Press).

Horiuchi, Akiyoshi and Qing-yuan Sui. 1993. "The Influence of the Japan Development Bank Loans on Corporate Investment Behavior" Journal of the Japanese and International Economics 7 (4).

Japan Development Bank, Japan Economic Research Institute. January 1993. Policy-Based Finance: The Experience of Postwar Japan (Tokyo).

Kim, Sun Bae. 1991. "Lenders cum Shareholders: How Japanese Banks Financed Rapid Growth." Ph.D. diss., University of Toronto. 
Komiya, Ryutaro, et al, editors. 1988. The Industrial Policy of Japan (San Diego: Academic Press).

Kosai, Yutaka. 1986. The Era of High-Speed Growth -- Notes on the Postwar Economy (Tokyo: University of Tokyo Press).

McKinnon, Ronald I. 1973. Money and Capital in Economic Development (Washington: Brookings Institution).

Nakamura, Takafusa. 1981. The Postwar Japanese Economy -- Its Development and Structure (Tokyo: University of Tokyo Press).

Okimoto, Daniel I. 1989. Between MITI and the Market (Stanford: Stanford University Press).

Packer, Frank. 1993. "Venture Capital, Bank Shareholding, and the Certification of Initial Public Offering Evidenced from the OTC Market in Japan" (Ph.D. dissertation essay, Columbia University).

Patrick, Hugh and Yung-Chul Park, editors. 1994. The Financial Development of Japan, Korea and Taiwan: Growth, Repression and Liberalization (New York: Oxford University Press).

Patrick, Hugh and Henry Rosovsky, editors. 1976. Asia's New Giant -- How the Japanese Economy Works (Washington: Brookings Institution).

Patrick, Hugh T., Editor. 1986. Japanese High Technology Industries: Lessons and Limitations of Industrial Policy (Seattle: University of Washington Press).

Patrick, Hugh. 1966. "Interest Rates and the Grey Financial Market in Japan", Pacific Affairs Winter, 1965-66.

Ramseyer, J. Mark and Frances McCall Rosenbluth. 1993. Japan's Political Marketplace (Cambridge: Harvard University Press).

Rauch, Jonathan. 1992. The Outnation: A Search for the Soul of Japan (Boston: Harvard Business School Press).

Rosenbluth, Frances. 1989. Financial Politics in Contemporary Japan (Ithaca: Cornell University Press).

Samuels, Richard J. 1987. The Business of the Japanese State: Energy Markets in Comparative and Historical Perspective (Cornell University Press).

Shaw, Edward S. 1973. Financial Deepening in Economic Development (New York: Oxford University Press)

Stiglitz, Joseph E. 1991. "Government, Financial Markets, and Economic Development," National Bureau of Economic Research Working Paper 3669, April. 
Stiglitz, Joseph and Andrew Weiss. 1981. "Credit Rationing in Markets with Imperfect Information," American Economic Review 71 (June): 393-410.

Suzuki, Yoshio. 1980. Money and Banking in Contemporary Japan (New Haven: Yale University Press).

Suzuki, Yoshio. 1986. Money, Finance and Macroeconomic Performance in Japan (New Haven: Yale University Press).

Suzuki, Yoshio, editor. 1987. The Japanese Financial System (Oxford: Oxford University Press).

Teranishi, Juro. 1990. "Financial System and Industrialization of Japan: 1900 - 1970," Banco Nazionale del Lavoro Quarterly Review 174 (September): 309-342.

Teranishi, Juro. 1993. "Emergence and Establishment of the Financial System in Postwar Japan -- Government Intervention, Indirect Financing and the Corporate Monitoring System" paper for World Bank "Asian Miracle" project, January 25.

Yamamura, Kozo and Yasukichi Yasuba, editors. 1987. The Domestic Transformation Volume 1 of The Political Economy of Japan under the general editorship of Yasusuke Murakami and Hugh T. Patrick (Stanford: Stanford University Press). 